Eliany Salvatierra Machado

\title{
Pelos caminhos de Alice: Vivências na Educomunicação e a dialogicidade no Educom.TV
}

Escola de Comunicações e Artes

Universidade de São Paulo

São Paulo - 2009 


\section{Pelos caminhos de Alice: Vivências na Educomunicação e a dialogicidade no Educom.TV}

Tese apresentada como exigência parcial para obtenção do grau de Doutora em Ciência da Comunicação (Interfaces Sociais da Comunicação Educomunicação) à Comissão Julgadora da Universidade de São Paulo, sob a orientação do Prof. Dr. Ismar de Oliveira Soares.

Escola de Comunicações e Artes

Universidade de São Paulo

São Paulo - 2009 
AUTORIZO A REPRODUÇÃO E DIVULGAÇÃO TOTAL OU PARCIAL DESTE TRABALHO, POR QUALQUER MEIO CONVENCIONAL OU ELETRÔNICO, PARA FINS DE ESTUDO E PESQUISA, DESDE QUE CITADA A FONTE.

Ficha Catalográfica

Serviço de Biblioteca

Escola de Comunicações e Artes

Universidade de São Paulo

Machado, Eliany Salvatierra

Pelos caminhos de Alice: vivências na Educomunicação e a dialogicidade no Educom.TV/ Eliany Salvatierra Machado. - São Paulo: Eliany Salvatierra Machado, 2008.

150 p. : il.

Tese (Doutorado) - Departamento de Comunicações e Artes / Escola

de Comunicações e Artes ECA/USP, 30/01/2009.

Orientador: Prof. Dr. Ismar de Oliveira Soares.

Bibliografia

1. Comunicação - Educomunicação

2. Educomunicação - diálogo

3. Educomunicação - práticas educomunicativas 
Eliany Salvatierra Machado

Pelos caminhos de Alice: vivências na Educomunicação e a dialogicidade no Educom.TV

\section{Banca examinadora}

Presidente:

Prof. Dr. Ismar de Oliveira Soares

Membros:

São Paulo, de

de 2009. 
Para:

Zeny de Salvatierra Machado, de quem herdei a força e a coragem e Raphael Alario Rodrigues dos Santos, meu companheiro sempre presente. 


\section{Minha Homenagem e gratidão...}

A Ismar de Oliveira Soares, pelos ensinamentos, confiança, orientação e principalmente acolhida na Educomunicação.

Aos amigos de caminhada: Patrícia Horta Alves, Maria Izabel Leão e Richard Romancini, por todas as conversas epistemológicas e sobre a vida.

A Ciro Marcondes Filho, pelo seu compromisso com a pesquisa, pela relação "Eu-Tu" e por tudo o que generosamente comigo compartilhou.

Aos colegas da pós-graduação: Danielle Naves de Oliveira, por suas sérias e profundas reflexões sobre a comunicação que me levaram a aprofundar os meus próprios estudos. Agradeço também Marco Toledo de Assis Bastos, Cristina Pontes Bonfiglioli, Tarcyane Cajueiro do Santos e Paulo Roberto Massela Lopes, pelos diálogos sobre a pesquisa na comunicação e outras tantas trocas.

A Mauro Wilton de Sousa pelos seus sábios conselhos.

A Arlindo Marchado, pelas conversas, conselhos e principalmente por ter me presenteado, por meio das suas provocações, com o tema da tese.

A Adilson Citelli, Marília Franco e José Eugénio de Oliveira Menezes, que sempre me auxiliaram pedagogicamente quando recorri a eles.

A Jorge Huergo, por ter me recebido carinhosamente e ter colocado suas pesquisas à disposição para estudo e análise.

À Família Kaplún, Mário (in memorium), pela herança reflexiva que nos deixou. Gabriel, pela amizade e confiança desses anos e à querida Inês, pelo carinho.

A Ana Paula Gonzaga, pelo seu compromisso, dedicado trabalho e generosidade.

A Anderson Volpato, pela leitura atenta dos textos da tese e nova amizade.

Aos amigos Luiz Carlos Rosante, pela parceria de tantos anos e Débora Cristina Piotto, amiga atenta e solidária.

A Valguima Victoria Vianna Aguiar Odakura, que esteve e está sempre presente independentemente de tempo e espaço.

À família Alario, pela acolhida e carinho: Vó Linda, Sônia, Cynthia e Sassá.

À minha família: mãe, Irmã e sobrinha: Zeny, Suely e Anik, pela compreensão da ausência.

Aos meus alunos que, nas trocas, me ensinam lições inesquecíveis.

À pós-graduação da ECA/USP e ao CNPq, pela bolsa que financiou a pesquisa. 


\title{
Cantares...
}

...Caminante, son tus huellas

el camino y nada más;

caminante, no hay camino,

se hace camino al andar.

\begin{abstract}
$\mathrm{Al}$ andar se hace camino
y al volver la vista atrás

se ve la senda que nunca

se ha de volver a pisar.
\end{abstract}

Caminante no hay camino

sino estelas en la mar...

Hace algún tiempo en ese lugar

donde hoy los bosques se visten de espinos se oyó la voz de un poeta gritar

"Caminante no hay camino, se hace camino al andar..."

Golpe a golpe, verso a verso...

\section{(António Machado)}




\section{RESUMO}

Pelos caminhos de Alice: vivências na Educomunicação e a dialogicidade no Educom.TV faz parte do nosso próprio percurso no campo da Comunicação e, principalmente, na Educomunicação. O que fazemos neste trabalho são perguntas, não para obter verdades absolutas, mas sim conseguir algumas respostas provisórias. O objetivo é pensar a Educomunicação enquanto fenômeno. Observamos o fenômeno educomunicativo com o auxílio da proposta criada por Marcondes Filho denominada de metáporos. Buscamos perceber os processos educomunicativos e o que há de novo neles. Descrevemos o projeto Educom.TV e analisamos os pressupostos da Educomunicação a partir de Ismar de Oliveira Soares, Mário Kaplún, Jorge Huergo, Ciro Marcondes Filho, Martin Buber e Emmanuel Lévinas. Durante a pesquisa, encontramos a palavra-princípio "Eu-Tu" e o conceito de “outro", mas, sobretudo, aprendemos que não somos nós que libertamos o outro: é o outro que nos liberta, que nos atravessa pelo diálogo.

\section{Palavras-chave:}

Educomunicação, Educom.TV, Diálogo, Ecossistema Comunicativo, O “Outro” na Educomunicação. 


\begin{abstract}
Pelos caminhos de Alice: vivências na Educomunicação e a dialogicidade no Educom.TV is the result of our own course in the Communication area, principally, in Educomunicação. What we made in this study are questions, not to obtain absolute truths, but to succeed in some provisory answers. The aim is to think about the Educomunicação as a phenomenon. We observed the Educomunicativo phenomenon base on the researches developed by Ciro Marcondes Filho, denominated Metáporos. We tried to perceive Educomunicativos processes and what's the news on it. We described the Educom.Tv project and we analysed the hypothesis of Educomunicação, in accord with Ismar de Oliveira Soares, Mário Kaplún, Jorge Huergo, Ciro Marcondes Filho, Martin Buber e Emmanuel Lévinas. During the research, we found the "principle-word" "I and Thou" and the concept of "Other", but, specially, we learned that we can not release the "Other": The "Other" releases us, whom goes through us the Dialogue.
\end{abstract}

\title{
Key-words:
}

Educomunicação - Educom.TV - Dialogue - "Ecossistema Comunicativo" - The "Other" in the Educomunicação 


\section{SUMÁRIO}

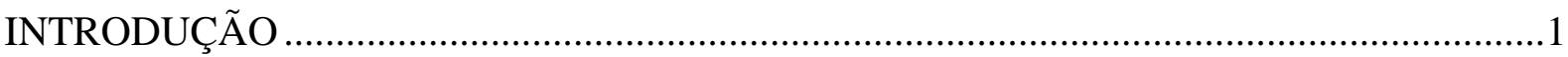

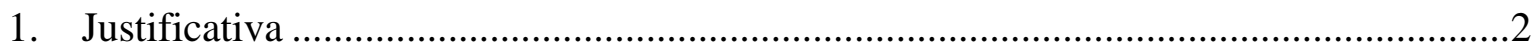

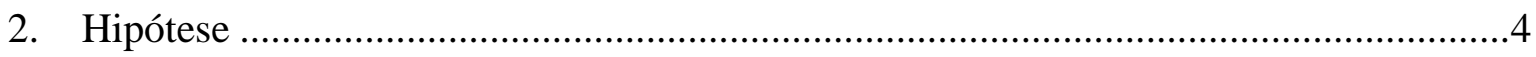

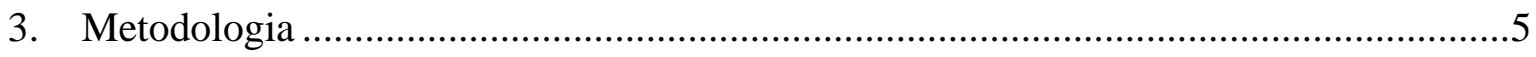

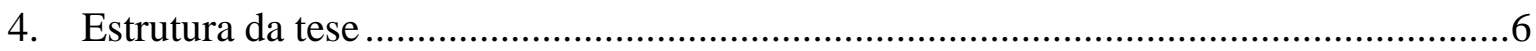

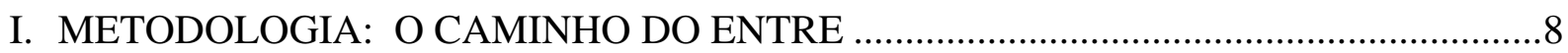

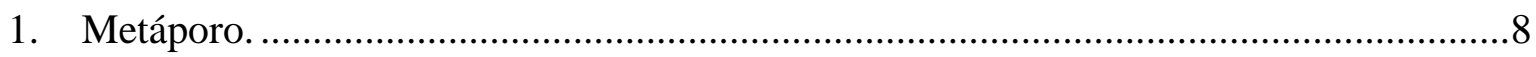

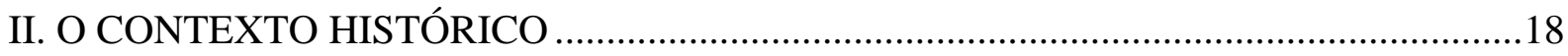

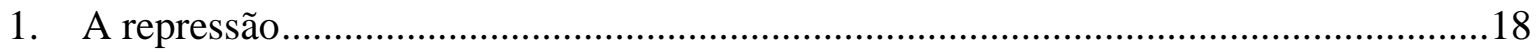

2. Por uma "Leitura Crítica" da Comunicação ................................................................23

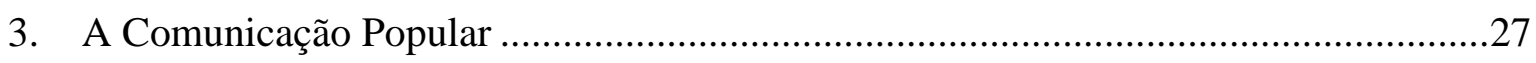

III. A EDUCOMUNICAÇÃO: UM POSSÍVEL CAMPO EMERGENTE DE

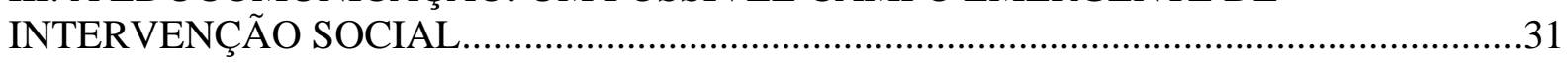

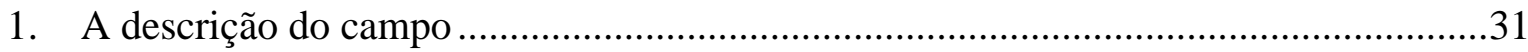

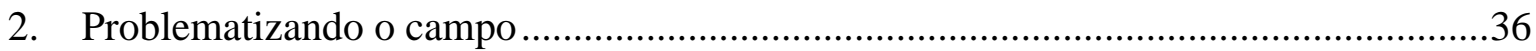

IV. MATRIZES EPISTEMOLÓGICAS: A EMANCIPAÇÃO E A DIALÉTICA DO

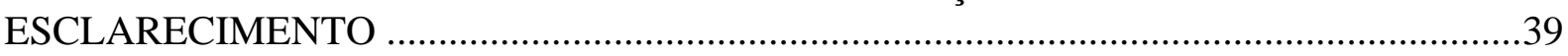

1. Mário Kaplún - O comunicador popular................................................................ 40

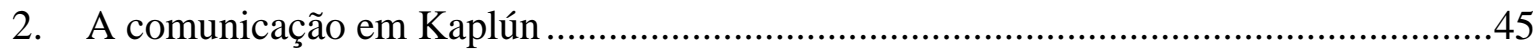

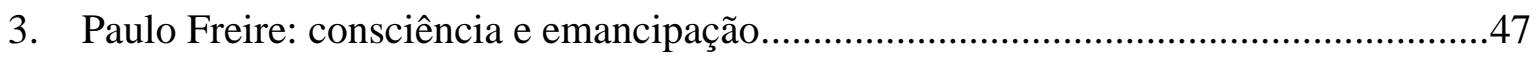

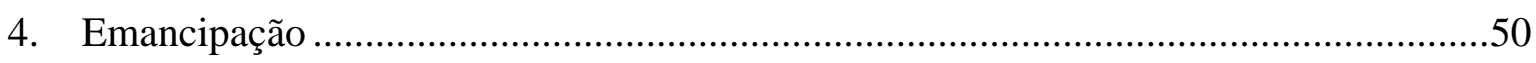

5. Emancipação, Aufklärung, esclarecimento..........................................................52

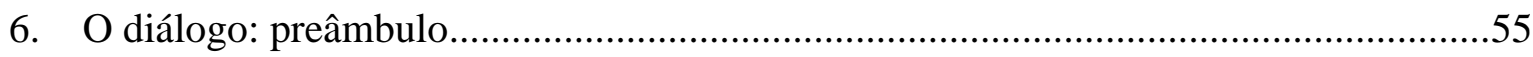

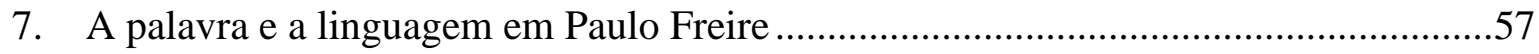

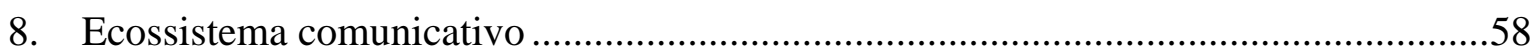


VI. ORA PEQUENA, ORA GRANDE: A RELAÇÃO NO DIÁLOGO ................................70

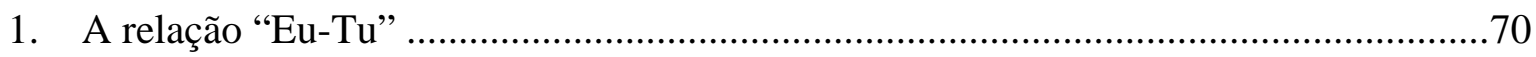

2. Ciro Marcondes Filho e as pesquisas sobre "o Princípio da Razão Durante". .............72

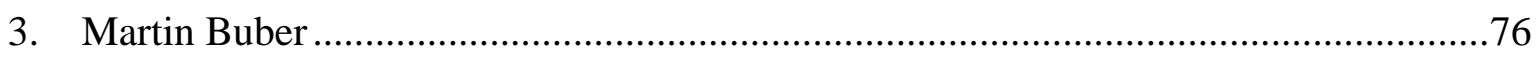

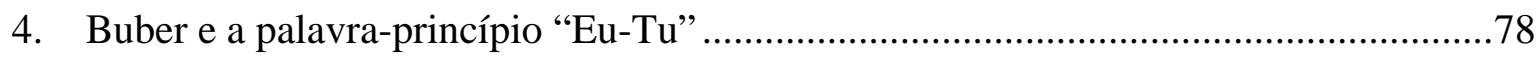

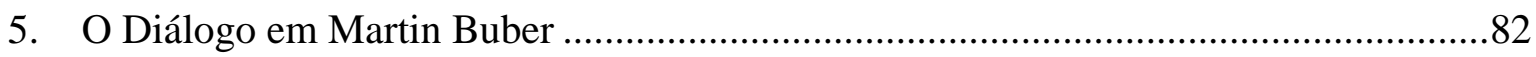

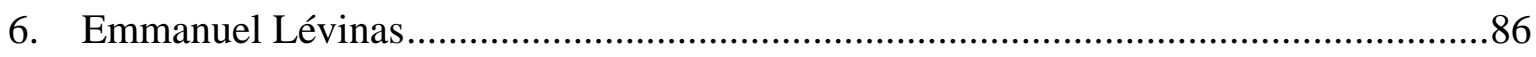

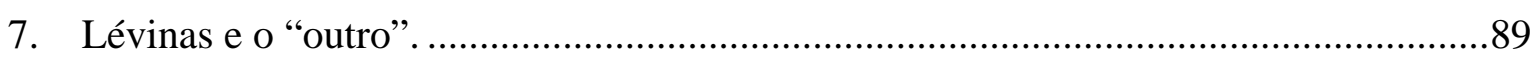

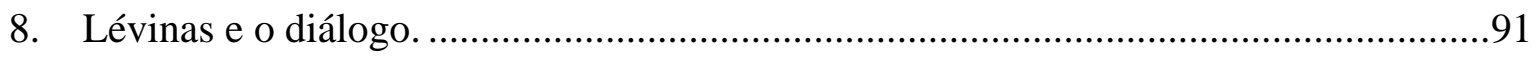

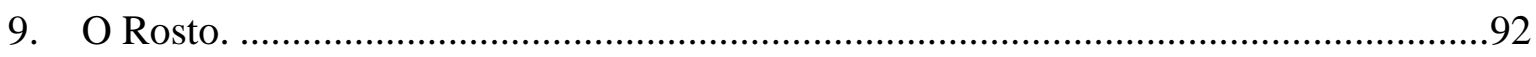

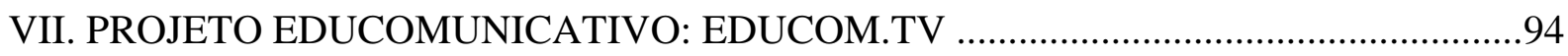

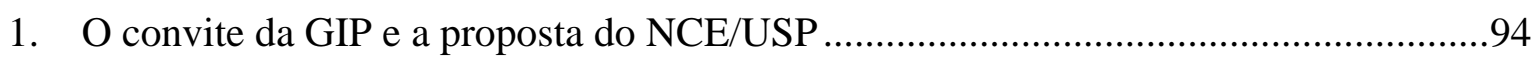

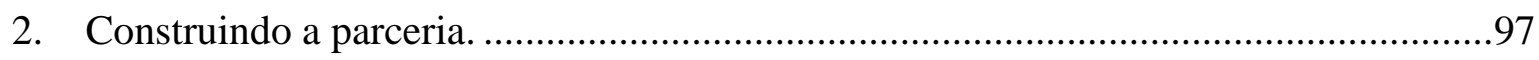

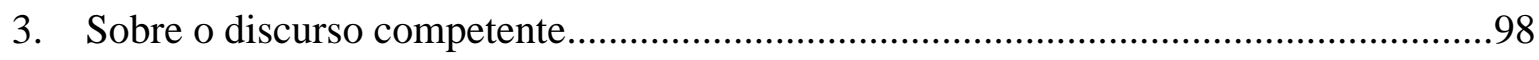

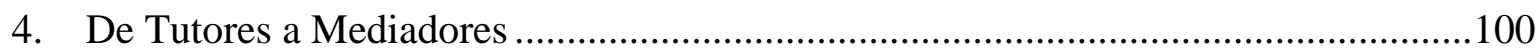

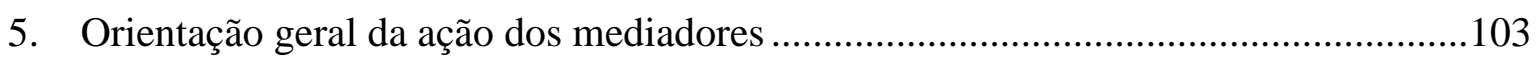

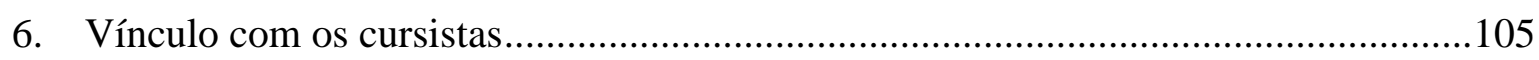

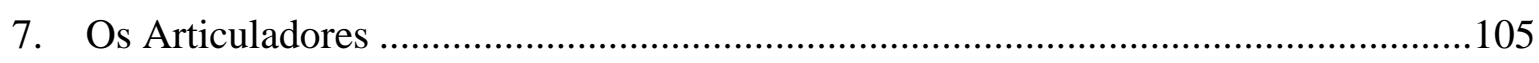

VIII. O AMBIENTE VIRTUAL DE APRENDIZAGEM NO EDUCOM.TV ....................107

IX. O CONTEÚDO PROGRAMÁTICO DO EDUCOM.TV ............................................116

X. OS ENCONTROS PRESENCIAIS E AS IMPRESSÕES NO EDUCOM.TV ................122

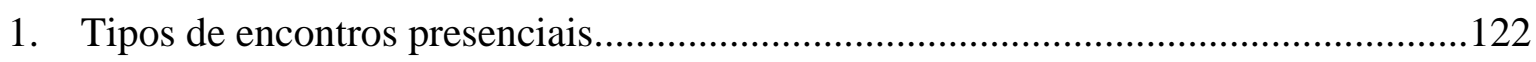

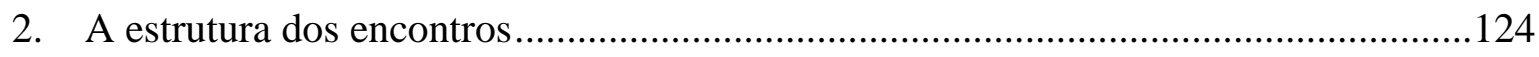

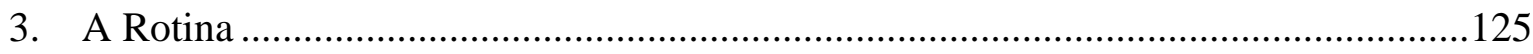




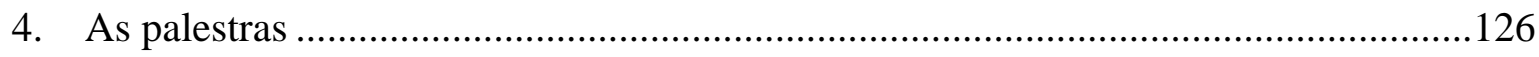

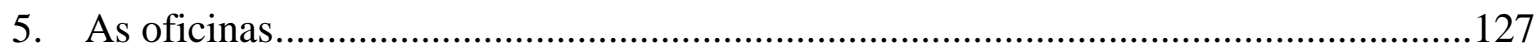

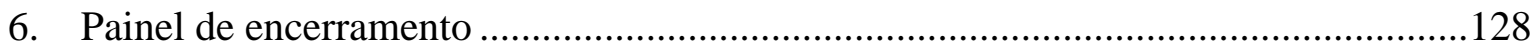

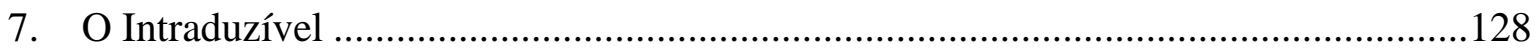

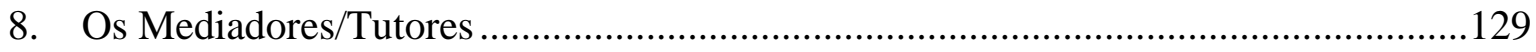

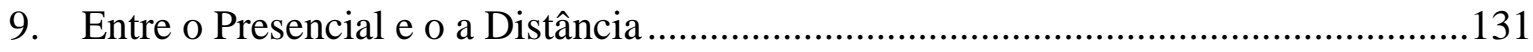

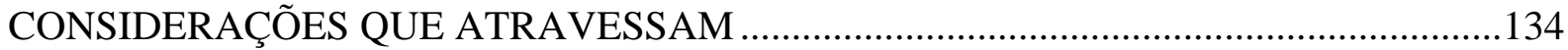

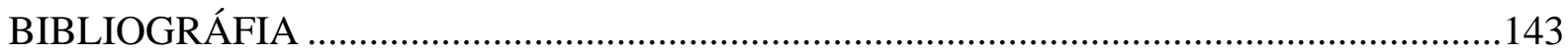




\section{INTRODUÇÃO}

A pesquisa Pelos caminhos de Alice: vivências na Educomunicação e a dialogicidade no projeto Educom.TV faz parte do nosso próprio percurso como agente cultural na interface entre a Comunicação, as Artes e a Educação ${ }^{1}$. Alice - personagem de Lewis Carroll em Aventuras de Alice no país das maravilhas e em Alice através do espelho e o que Alice encontrou lá - é essencialmente uma menina que faz perguntas e é ela que da o tom para a nossa caminhada.

O que fazemos inicialmente são perguntas, não para obter verdades absolutas, mas para contar com algumas respostas provisórias. Segundo a filosofia de Carroll, a grande aventura está em se permitir perguntar e, daí, em aprender, em conhecer o diferente, o novo. Por isso, o objetivo deste trabalho é fazer perguntas para pensar a Educomunicação.

O convite é pensar sobre o novo campo, já identificado pela pesquisa do NCE/USP, em 1999, como veremos nos próximos capítulos, reconhecendo, a princípio sua existência e legitimidade. O caminho é o resgate do seu contexto histórico, de seus meandros, de suas fugacidades, não propriamente a partir de confrontos teóricos, mas tendo em conta, existencialmente, nossa própria vivência em programas educomunicativos. Para tanto, elegemos, como campo de observação, o projeto Educom.TV - a linguagem audiovisual na sala de aula, um curso semi-presencial oferecido pelo Núcleo de Comunicação e Educação da ECA/USP, em 2002, para mais de dois mil professores da rede estadual de educação.

O ponto inicial foi, portanto, a nossa experiência. A partir da memória que construímos sobre o Educom.TV, narramos o que nos passou, os autores que nos auxiliaram a refletir sobre o fenômeno em pauta e as descobertas que nos foi possível perceber e sistematizar.

Desde 1996, participando de várias atividades do NCE, inclusive da pesquisa que pela primeira vez descreveu e definiu o novo campo, acabamos por escolher a Educomunicação como nosso objeto de trabalho, somando os nossos esforços aos dos pesquisadores que nos

1 Sou formada em ensino das Artes (UFMS, 1994), com mestrado em Ciências da Comunicação pela ECA/USP (2002). 
precederam nas investigações sobre o desenvolvimento do tema, especialmente através a análise dos projetos do próprio NCE/USP.

Nossa meta é, pois, colaborar para as reflexões sobre o campo e suas especificidades a partir de uma metodologia fenomenológica, pela qual o fenômeno fala por si mesmo, necessitando ser lido e entendido a partir de seu próprio âmbito e âmago.

Outra meta é a de contribuir para o reconhecimento do campo, por suas práticas, colaborando desta forma para a formação de futuros Educomunicadores.

\section{Justificativa}

Acompanhando o NCE, temos observado uma crescente demanda por projetos de extensão destinados à formação e capacitação de profissionais voltados para a Educomunicação. Tais solicitações partem de empresas (como o Canal Futura), de escolas isoladas ou, mesmo, de organismos vinculados a Secretarias de Educação de municípios (como ocorreu nas cidades de São Paulo e de São José dos Campos), de estados (como as Secretarias de Educação dos Estados de São Paulo, Mato Grosso, Mato Grosso do Sul e Goiás) ou ainda do Governo Federal (como os Ministérios da Educação, do Meio Ambiente e do Trabalho). Segundo dados da Secretaria do NCE/USP, entre 1998 e 2008, foram atendidos mais de 20 mil cursistas, vinculados a aproximadamente 2.500 escolas em todo o país. Para tanto, o NCE criou projetos de grande extensão, como o Educom.Rádio (para 12 mil pessoas, entre professores, alunos e membros da comunidade); o Educom TV (para 2.240 pessoas); o Educomrádio.Centro-Oeste (para 2.500 pessoas na região Centro-Oeste, entre professores e alunos do ensino médio); o Educom.Geração Cidadã (para 2.000 jovens, numa proposta vinculado ao Ministério do Emprego e do Trabalho), além de projetos menores em sua abrangência, como o Educom.Saúde (para a Secretaria de Saúde do Município de São Paulo); o Educom.São Luís, o Educom.Fundhas e, mais recentemente, o Educom.Mídias (com ele retornando aos projetos de grande dimensão, com mais de 3.500 professores do Estado de São Paulo). Em maio de 2008, a ECA/USP, por intermédio de sua Congregação, aprovou o curso de graduação na área (a Licenciatura em Educomunicação), em estudos junto à Reitoria da Universidade. 
O conjunto dessas ações aponta não somente para a existência do campo, mas especialmente por seu reconhecimento público, para sua legitimidade junto às instâncias que definem o sentido das práticas sociais.

Mas, afinal, o que é Educomunicação? Ou melhor, o que compreendemos por Educomunicação? Quais são as referências teóricas que nos ajudam a pensar os fundamentos deste campo emergente? Quais são seus pressupostos? O que caracteriza um projeto ou uma prática educomunicativa? Estas e outras perguntas traduzem diariamente as dúvidas, tanto dos que se deparam com o conceito pela primeira vez, quanto dos que atuam no campo há mais de uma década.

Com a expansão da Educomunicação e com o crescimento do número de comunicadores e educadores interessados em trabalhar no novo campo, vislumbrou-se a necessidade de relatar e registrar as ações já realizadas. Organizar, desta forma, referências para o auxílio a futuros projetos de pesquisa ou de práticas tornou-se uma necessidade premente.

$\mathrm{O}$ trabalho de sistematização das pesquisas no campo, especialmente as relacionadas as atividades do NCE, tiveram início desde o momento da fundação do Núcleo. Atualmente, a Biblioteca da ECA/USP já conta com mais de cinqüenta trabalhos. Entre eles: monografias de especialização, dissertações de mestrado e teses de doutorado em torno da Educomunicação, como se pode constatar na tese de doutorado de Richard Romancini sobre $O$ campo científico da Comunicação no Brasil:institucionalização e capital científico, defendida em 2006.

Especificamente sobre os projetos do NCE/USP, encontramos as pesquisas de Patrícia Horta Alves. Educom.rádio - Uma política pública em educomunicação, tese de doutorado defendido em 2007; Marciel Aparecido Consani. Mediação tecnológica na educação: conceitos e aplicações, tese defendida em 2008; Renato Tavares Júnior. Educomunicação e Expressão Comunicativa: a produção radiofônica de crianças e jovens no projeto educom.rádio, dissertação de mestrado, defendia em 2007; Claudia Vicenza Funari Sá Borges. A prática da mediação em processos educomunicacionais: o caso do projeto educom.rádio, dissertação de mestrado, defendida em 2007 e Maria Izabel Leão, $O$ papel da Internet nos projetos educomunicativos do NCE/USP, defendida em 2008, sem contar uma dissertação de mestrado em conclusão na Faculdade de Educação de Mauro Cordeiro Soares e uma segunda, no Instituto de Psicologia da USP, de Joari Aparecido Soares de Carvalho 
Neste contexto, nossa tese justifica-se pela necessidade de um mergulho na prática do NCE através de uma ótica diferenciada, propiciada, como adiantamos, pela fenomenologia revisitada por Ciro Mardondes Filho, tendo como objeto a observação de um dos projetos do Núcleo o Educom.TV.

\section{Hipótese}

Não pretendemos discutir a existência ou não do campo da Educomunicação. O nosso maior esforço, no presente trabalho, consiste em pensar o referido campo como algo que mobiliza as pessoas, observando seus fundamentos ou aquilo que em outra perspectiva científica poderia ser nomeado como "a natureza própria do objeto". A diferença reside no fato de que a noção de "natureza" remete originalmente a algo dado, que "é", que nasceu ou surgiu em algum momento e se firmou, e que de alguma forma é considerado como imutável. Ao contrário, a perspectiva que ora adotamos é a de um campo vivo, dinâmico, em movimento.

A nossa hipótese provisória nos aponta para a aceitação da visão fenomenológica segundo a qual a Educomunicação é o espaço do "entre", onde a dialogicidade humana acontece quando mediada pelos sujeitos sociais, de forma franca e aberta, com a contribuição dos processos e recursos da comunicação. Fenômeno de difícil mensuração, mas absolutamente fácil de vivenciar.

O caminho da hipótese, nas pesquisas científicas racionalistas, está marcado pela chegada, pela busca da verdade através dos dados exatos, resquícios ou herança das ciências duras. Na nossa pesquisa, a hipótese segue a intuição, fonte de inspiração, luz que nos ajuda a perceber. 


\section{Metodologia}

Para realizar o nosso estudo, depois de percorrermos o contexto histórico que possibilitou o reconhecimento do conceito da Educomunicação, nos decidimos pelo mergulho na prática. Nos afastamos, portanto, dos preceitos da metodologia tradicional de pesquisa científica, que a condiciona ao distanciamento entre o pesquisador e o objeto. Não é nosso propósito, igualmente, utilizar os referenciais da denominada metodologia participante, igualmente pautada pela racionalidade dos procedimentos, ainda que não desconsidere a subjetividade do pesquisador. O que nos propomos é adotarmos a proposta "metodológica" nomeada por Ciro Marcondes Filho como metáporos ou "caminho do meio", do "entre", onde a subjetividade não é fator secundário, mas é parte essencial do processo, uma vez que nela se reconhece a condição de observador efetivo e testemunha dos acontecimentos.

A metodologia no presente trabalho será, pois, guiada pelo metáporos que reconhece o seu objeto como fugidio, em movimento, fugaz. Através do metáporos narramos o projeto Educom.TV, tentando lembrar e descrever as sensações, aquilo que fez com que o curso fosse um sucesso ou um grande encontro, para a autora e para os que com ela conviveram a experiência, especialmente os coordenadores, tutores e a equipe operacional do projeto.

Para nos auxiliar a pensar e a enxergar a Educomunicação como fenômeno, nos valemos, num primeiro momento, de Ismar de Oliveira Soares, Mário Kaplún e Paulo Freire por considerá-los fundadores do novo campo. Ouvimos e consultamos, também, por meio de entrevista gravada, o pesquisador: Jorge Huergo, da Argentina, pela importância de seu trabalho na sistematização e crítica do campo Comunicação/Educação em seu país.

Para nos ajudar a apensar o diferente, o inusitado e o novo, buscamos Ciro Marcondes Filho, Martin Buber e Emanuel Lévinas. O primeiro, como já afirmamos, na definição do caminho da pesquisa e os dois últimos por nos permitir um esquema de reflexão. Os dois são pouco conhecidos dos estudiosos do campo da Comunicação, sendo autores mais lidos na área da Filosofia. Por isso mesmo estão em condições de nos ajudar a refletir sobre as nossas práticas, no contexto do que o campo nos propõe: aquilo mesmo que os dois autores denominam como a relação "Eu-Tu" e o "outro". 
São estes os nossos caminhos. Contudo, como alerta o poeta António Machado, “caminhante, são teus rastos, o caminho e nada mais; caminhante, não há caminho, faz-se caminho ao caminhar”, sejamos todos bem-vindos a Educomunicação.

\section{Estrutura da tese}

O trabalho está estruturado em dez capítulos, sendo o último dedicado à conclusão.

O primeiro capítulo, nomeado de Metodologia: o caminho do entre, tem como o objetivo auxiliar o leitor a entender o caminho a ser percorrido pela pesquisadora ao longo de todo o trabalho. É justamente neste momento inicial da tese que apresentamos a proposta metodológica de Ciro Marcondes Filho denominado metáporos.

No segundo capítulo, intitulado Contexto Histórico, resgatamos alguns fatos políticos que marcaram o período em que seu deu a formação da Educomunicação. A história do Brasil, marcada, no início da segunda metade do século XX, por governos autoritários e repressores, permitiu o surgimento, no cenário nacional, de "grupos de resistência" que passaram a atuar em todas as áreas da atividade humana, inclusive no campo da prática comunicativa, favorecendo com isso o surgimento de projetos com viés crítico. A Educomunicação surgirá como uma resposta da sociedade à violenta fragmentação da prática social, buscando garantir dialogicidade comunicativa à prática educativa.

No terceiro capítulo, A Educomunicação: um possível campo emergente de intervenção social, apresentamos o conceito a partir da pesquisa sobre a relação entre a Comunicação e a Educação na América Latina, promovida pelo NCE/USP, sob a coordenação de Ismar de Oliveira Soares, entre 1997 e 1999. Trabalhamos com o conceito de campo científico e de suas especificidades.

No quarto, quinta e sexto capítulos, reunimos as referências teóricas de natureza predominantemente filosófica que orientaram a pesquisa, detendo-nos em autores como Soares, Kaplún, Freire, Huergo, Marcondes Filho, Buber e Lévinas. 
Dedicamos o oitavo, nono e décimo capítulos à descrição do projeto Educom.TV, dissertando sobre a parceria realizada entre a Secretaria de Educação do Estado de São Paulo e o NCE para levar a educomunicação á rede pública. Falamos da estrutura do curso, do ambiente virtual de aprendizagem, do conteúdo programático, dos encontros presenciais, da relação entre tutores e cursistas.

Por último, o capítulo décimo primeiro - Considerações que atravessam - narra as percepções e as sensações que afloraram durante o projeto e que traduziram a essencialidade dialógica da proposta, concretizando a palavra-princípio "Eu-Tu", deixando denotado, desta forma, que estávamos diante de um fenômeno educomunicacional. 


\section{METODOLOGIA: O CAMINHO DO ENTRE}

Nossa proposta metodológica para a presente tese tem, nos trabalhos de Ciro Marcondes Filho, sua fundamentação. Vejamos:

\section{Metáporo.}

Após vinte anos estudando o território dos fenômenos comunicacionais e suas ocorrências fenomenológicas, Marcondes Filho apresenta, em 2008, o debate sobre o "Metáporo" 2 , que faz parte do trabalho Princípio da razão durante, uma ontologia e uma epistemologia que norteou suas investigações ao longo do período. O Metáporo está relacionado, com o que tradicionalmente se entende por "método" de pesquisa. Esta é a proposta que vamos apresentar na orientação de nossa caminhada.

As noções vigentes de metodologia e método divergem em alguns aspectos em relação à proposta metapórica, já que ela escapa dos pressupostos tradicionais. Segundo Marcondes Filho, o termo "método" carrega a idéia de caminho já traçado (meta + odos = caminho que vai para o outro lado). Ao que ele considera: "percurso necessário, camisa de força da pesquisa, conjunto de procedimentos estabelecidos aos quais ela tem que se dobrar."

O Metáporo é uma proposta que respeita o seu objeto (comunicação), sua fugacidade, sua efemeridade e o caráter fortuito do acontecimento comunicacional. Cabe ressaltar que, para o autor, comunicação não é coisa, nem via de acesso, e muito menos uma transmissão que sugere troca, compartilhamento ou, pior, meios técnicos. Comunicação para ele é "Acontecimento".

Durante o percurso que realizamos, ao entrar em contato com os trabalhos do pesquisador, notamos que, apesar das carências de nosso conhecimento filosófico, ele nos

\footnotetext{
${ }^{2}$ Ciro MARCONDES FILHO, Princípio da Razão Durante: por uma teoria do acontecimento em comunicação, 2008 (circulação restrita).
} 
estimula a exercitar a reflexão, sobretudo, a análise crítica acerca do que estamos pesquisando.

Com uma postura ainda tímida, buscamos em pensadores como Buber e Lévinas referências que nos auxiliassem a pensar a Educomunicação. Entretanto, faltava uma proposta "metodológica" que fosse condizente com o que vínhamos pensando e estudando. Foi nesta perspectiva que a proposta metáporica veio ao encontro de nosso desejo.

Por isso, apresentaremos primeiro a proposta de Marcondes Filho, para depois continuarmos o nosso caminho. Talvez esta opção possa vir a ser considerada um caminho inadequado. Mas, segundo Feyerabend: "as normas científicas existem para serem burladas e isso é o que garante o progresso no saber". ${ }^{3}$

O Metáporos demanda um olhar diferente para a comunicação, por isso é importante rever algumas características básicas do acontecimento comunicacional, que segundo Marcondes Filho são:

1. O objeto é novo, ágil, cobrando do procedimento investigativo uma atitude igualmente dinâmica;

2. O objeto é transitório, exige que o pesquisador atribua legitimidade a esse estado passageiro;

3. O objeto está assentado no movimento, daí impondo ao estudioso uma atitude emparelhada no mesmo processo;

4. O acontecimento não avisa que irá se dar: cabe ao pesquisador a identificação de sua fulguração e a iniciativa de acompanhá-la.

As quatro características - novidade, efemeridade, movimento e imprevisibilidade - ficam mais evidentes quando as definimos segundo a razão inversa: o objeto não é conhecido nem conceituado; não permanece por muito tempo; não está parado, estacionado ou “congelado" e, por último, não avisa quando irá acontecer novamente.

\footnotetext{
${ }^{3}$ Paul Feyerabend, 1991b, p. 123 apud. Ciro MARCONDES FILHO, Princípio da Razão Durante: por uma teoria do acontecimento em comunicação, 2008 (circulação restrita).
} 
Quando pensamos na Educomunicação, pensamos a partir da comunicação: campo dinâmico, complexo e em movimento. Educomunicação, nesta perspectiva, seria o campo propício para poder, em posição de vigília, aguardar o acontecimento.

A proposta da Educomunicação tem como pressuposto perceber e estar aberto ao outro, possibilitando o diálogo. Queremos, agora, narrar o acontecimento, com o auxílio do que ouvimos, vimos e também experimentamos. Pensar a Educomunicação, assim como percebê-la, ainda não é propriamente uma atitude metapórica. Contudo, a proposta já orienta a nossa escrita.

Segundo Marcondes Filho: "comunicação é um acontecimento que produz o novo. A emergência do nunca-antes-dado, daquilo que marca o inusitado, o inesperado, o incomodante, o perturbador, o "irritante". E são estes "atributos", se é que podemos chamálos assim, que surpreenderiam o pesquisador convencional, cuja intenção é exatamente a de neutralizar esse novo, atribuindo-lhe um nome, um conceito, uma definição.

Há, atualmente, nas discussões sobre o campo da comunicação, aquilo que consideramos como preocupações duais. São inquietações sérias e verdadeiras do ponto de vista de quem as realiza. Porém, estão centradas na discussão do que é a comunicação na tradição da racionalidade ocidental.

A dualidade está nos extremos, não buscando o caminho do meio, ou o caminho que vai pensar sobre a comunicação do ponto de vista fenomenológico. O que é a comunicação? As preocupações dualistas acabam se tornando tão rígidas que procuram tudo comprovar e, conseqüentemente, nomear. Em decorrência disto, perdem o insondável, o movimento.

No caso de nosso objeto, a necessidade de dar nome às coisas e definir o que elas são tem levado pessoas que trabalham em projetos sociais, como os jornalistas, a exigirem uma definição exata de Educomunicação. Ao que nos coube sempre responder: podemos dizer o que está sendo ou, ainda, o que alguns consideram que é.

Educomunicação, como costuma dizer Soares em suas palestras, é um campo emergente de atuação, com projetos, práticas e diversas pessoas trabalhando. O que observamos, contudo, depois de doze anos na área, é que cada um faz a sua Educomunicação, a que entende ou a que é melhor para o projeto que coordena, fatos que nem sempre estamos de acordo. 
Posso dizer o que para nós não é Educomunicação. Mas como esta é uma área dinâmica, pode ser que ela se torne, ou que já seja aquilo que nem gostaríamos que fosse. Não nos cabe aprisionar o que está vivo. Sendo assim, a nossa proposta não é dizer o que é a Educomunicação, mas olhar para a área e descrevê-la em seus movimentos particulares.

Segundo Marcondes Filho, no caso da comunicação, "a estratégia da neutralização pelo conceito, pelo nome, busca tranqüilizar, assegurar, acalmar os espíritos mais excitados. Não obstante, ao mesmo tempo, cala exatamente essa fulguração inovadora do acontecimento." 4

No Metáporo, escreve Marcondes Filho, cabe apelar para a estratégia de uma preservação do não-conhecido, do ainda-não-desvendado, assegurando-lhe a potencialidade de continuar a existir. Sob este ponto de vista, podemos falar sobre a Educomunicação, sistematizar o que pensamos e o que vivenciamos, mas nos reservaremos à prerrogativa de não dizer o que é. Vamos, fundamentalmente, narrar seu movimento.

No campo do saber, principalmente na academia, assim como no campo da sociedade em geral, a emergência do novo desestabiliza relações de poder e de legitimidade estabelecidas. A reação é tentar reprimir o novo, especialmente o que é marginal, o que não é considerado e que ainda se rebela contra uma ordem lógica.

Nossa busca teórica vê a comunicação como a emergência incansável do novo, eterna indeterminação, jogo de significações flutuantes, disputa entre corpo e fala, símbolos e índices, enunciado e enunciação, comunicação e informação, analógico e digital. ${ }^{5}$

Marcondes Filho explica: o pesquisador precisa se misturar, fazer o jogo para pegar o enredo, acompanhar os movimentos, participar do clima, imergir no processo para viver com ele, para sentir sua pulsação. Neste sentido, ao contrário do que alguns métodos de pesquisa propõem (o afastamento, a objetividade e a imparcialidade), o Metáporo fala da "mistura", do "fazer parte". O que pode causar estranhamento é justamente o que nos atrai.

\footnotetext{
Não se trata de apreender nem de compreender mas de sentir suas vibrações, sua força, sua energia própria e encontrar uma forma de apresentá-lo ao outro, repassá-lo, de manter os efeitos vibrantes. O trabalho de compreensão cabe aos estudos paracomunicacionais, com a sociologia, a história, a psicologia, a psicanálise e as teorias lingüísticas, semióticas e semiológicas. O campo da comunicação, diferentes destes, é o da identificação de uma comunicabilidade, de sua descrição, assim
}

\footnotetext{
${ }^{4}$ Ciro MARCONDES FILHO, Princípio da Razão Durante: por uma teoria do acontecimento em comunicação, 2008 (circulação restrita).

${ }^{5}$ Ibid.
} 
como dos mecanismos de transformação operados por ela tanto em indivíduos isolados como em fenômenos sociais de maior alcance. ${ }^{6}$

O desafio é conseguir pensar em uma ciência transitória. Um saber que se dedique ao instável, àquilo que só se mostra neste exato momento por efeito das forças que interagem aqui e agora. Desta maneira, esse processo nunca será capturado em sua totalidade, pois é sempre transitivo, escapa entre os dedos: em momento algum irá permitir ser capturado.

Por isso, ao descrever o projeto Educom.TV, recorremos a documentos e à memória, mas não à descrição do acontecimento comunicacional, pois este já foi, já passou. O que podemos descrever são os fenômenos que vivenciamos e observamos no agora, no instante do ocorrido.

Bergson, ${ }^{7}$ filósofo francês, optava pelo estudo do movimento, pois para ele, a ciência havia se cristalizado, falando da crisálida, quando, em realidade, havia uma borboleta que dela emergia e que não era sequer considerada. Mobilidade em vez de paralisia, fluidez em vez de estagnação, duração no lugar da temporalidade: abstração.

Do ponto de vista filosófico, para Marcondes Filho, não era somente possível, mas necessária, uma ciência do movimento, do transitório, um saber da própria mutação, um conhecimento que captasse as coisas em suas mudanças permanentes. Assim, "acreditar no movimento, na borboleta, na duração é fazer uma escolha: em vez de seres (a metafísica da presença), somente acontecimento e fatos." 8

A questão não é pesquisar seres, mas o fato, o entre: "O ser heraclitiano, diz Michel Conche, não passa de uma aparência de estabilidade recortada - pela linguagem, pelo desejo, pela tradição - na insubstancialidade do devir." 9

Os acontecimentos comunicacionais não são somente novos, ágeis, inesperados; não estão apenas em movimento, transitórios, mutantes eternos. São também inesperados. "Sua temporalidade é sem presente" - o efêmero já aconteceu.

\footnotetext{
${ }^{6}$ Ciro MARCONDES FILHO, Princípio da Razão Durante: por uma teoria do acontecimento em comunicação, São Paulo, 2008 (circulação restrita).

${ }^{7}$ Henri Bergson, apud., Ciro MARCONDES FILHO, op. cit., p. 4.

${ }^{8}$ Ciro MARCONDES FILHO, Princípio da Razão Durante: por uma teoria do acontecimento em comunicação,

p. 4.
${ }_{9}$ Ibid.
} 
Como diz Baudrillard, precisamos, por isso, ficar pacientemente aguardando. A teoria só pode ser isso, diz ele, 'uma armadilha preparada na esperança de que a realidade seja suficientemente ingênua para se deixar apanhar". ${ }^{10}$

O pesquisador, nessa linha de pensamento, deve focalizar o exame da ocorrência, como esta se dá, que efeitos provoca, qual a lógica de seu impacto, de sua atração, de seu mecanismo de sedução, numa atitude em que "não se visa um saber final, uma construção a ser reverenciada, uma descoberta que irradie pelos tempos futuros". Este mesmo pesquisador pode escolher entre aprisionar o objeto ou descrevê-lo, deixando-o livre. Também é possível, nessa mesma perspectiva, escolher o objeto ou o tema. Tudo depende de nossos valores. Temos a opção da escolha. Contudo, "sabemos que aquele que atrapalha a rainha ou está contra ela recebe a seguinte sentença: "cortem-lhe a cabeça!”

"Interpretar é vontade de poder". ${ }^{11}$ O objetivo é "chegar a uma apreensão do real a partir das formulações bergsonianas, tentando compatibilizá-las com um modo de realização de pesquisa em comunicação que façam jus à natureza de seu objeto que, ao que tudo indica, nunca foi pesquisado como deveria." 12

Para Bergson, um método científico não pode ser nem idealista, nem empirista:

Bergson funda um conhecimento filosófico apoiado sobre um procedimento crítico mais do que sobre uma intuição ou uma descrição positiva, mas de fato, Bergson é um antiintelectualista que faz da intuição um método. Bergson significa, como os autores anteriores, uma crítica à ciência empírica a ao idealismo kantiano, à dialética hegeliana mas, também ao psicologismo, particularmente de William James. A crítica da ciência em geral é realizada por Bergson a partir da discussão das categorias de tempo e espaço. No campo da psicologia, o filósofo investe contra a psicofísica de Fechner [Cf. cap. $5^{\mathrm{a}}$ ]. Intuição como método. Deleuze via contradição no fato de um método poder apoiar-se na intuição, já que esta é imediata, instantânea, enquanto aquele exige mediações. Mas Bergson não duvida, diz que a simplicidade não exclui uma multiplicidade qualitativa e virtual. Mais especificamente, Bergson recusa-se a fragmentar a experiência como o fazem os empiristas e mesmos seus críticos, os dogmáticos, que, conforme Bergson, seguem pela mesma via. ${ }^{13}$

Nesta linha de raciocínio, o Metáporo se inicia pela apreensão do fenômeno por intermédio da intuição sensível e intelectual. Não se trata de um método dedutivo, tampouco indutivo, "mas da apresentação de constatações, impressões ou descrições relativas a um fenômeno comunicacional específico.”

\footnotetext{
${ }^{10}$ Baudrillard, p. 117. apud. Ciro MARCONDES FILHO, op. cit., p. 5.

${ }^{11}$ Op. cit., Ciro MARCONDES FILHO, p. 11.

12 Ibid., p. 14.

${ }^{13}$ Marcondes Filho coloca sempre em seus textos alguns detalhamentos que são: comentários, citações ou indicações de leituras. Escolhemos destacar este detalhamento sobre Bergson para auxiliar o leitor na passagem anterior, onde escrevemos que Marcondes Filho segue "formulações bergsonianas". op. cit., Ciro MARCONDES FILHO, p. 16.
} 
A intuição, para Bergson, é um conhecimento sui generis, comparável ao instinto e ao senso artístico, que nos revela aquilo que os seres são em si próprios, por oposição ao conhecimento discursivo e analítico que exerce uma abordagem do conhecimento do exterior. Assim, o Metáporo toma como modo de apreensão do real a captura instantânea, sensível, sem conceitos, tal qual se observa na relação estética com o mundo. Ele permite um tipo de inferência pela qual podemos captar o que não está presente. A evidência não é exterior, como pensava o idealismo, mas do próprio mundo, do mundo vivido, explica Marcondes Filho.

Com a intuição sensível, com o ato de nos transportarmos para o interior de um objeto, realizamos a simpatia, isto é, fundimo-nos com o que há de único no objeto. Diferente das ciências positivas, o Metáporo não analisa, não adota um ponto de vista sobre a coisa, não disserta sobre ela, mas busca captá-la no próprio objeto. É como a cor, diz Bergson, em que eu me envolvo no alaranjado a partir de minha imersão nele, não o vendo como uma cor entre o vermelho e o amarelo. ${ }^{14}$

A questão para nós, na presente pesquisa, não é tratar da Educomunicação como Educação ou como Comunicação. É tratar a Educomunicação como Educomunicação, mesmo que isso pareça estranho, novo demais, diferente, já que o nome remete às duas áreas.

Marcondes Filho nos ensina que apreender a coisa está, portanto, vinculado à subjetividade do pesquisador que será legitimada ou não. Sua legitimidade ocorrerá pelo fato de outros se reconhecerem naquilo que foi descrito. "A figura do pesquisador, na formulação metapórica, portanto, é a daquele que descreve cenas, situações, mundos. Ele é um espectador do mundo". ${ }^{15}$ É o que esperamos. Que o pesquisador leitor deste texto tenha em mãos algo vivo, pulsante.

O pesquisador deve considerar três coisas: que ele é um observador ou, nas palavras de Marcondes Filho, um espectador que, em movimento, vê a vida também em movimento. A segunda é o lugar do pesquisador no Metáporo: estamos no mundo, não estamos fora dele ou suspensos, ou seja, não estamos desconectados. A terceira é que o mundo, em movimento, nos dá uma "infra-estrutura de operações do pensamento, nos dá um campo aberto, um espaço livre do saber."

Gilles Deleuze sugere, para tanto, o conceito de 'espaço liso', que é considerado e seguido durante a investigação, em oposição ao 'espaço estriado'. O saber, segundo ele, não está atrás de constantes nem de leis a partir de variáveis; as vê apenas como variações contínuas, captando singularidades da matéria. ${ }^{16}$

\footnotetext{
${ }^{14}$ Ciro MARCONDES FILHO, Princípio da Razão Durante: por uma teoria do acontecimento em comunicação, 2008 (circulação restrita).

${ }^{15}$ Ibid., p. 40.

${ }^{16}$ Gilles Deleuze. apud. Ciro MARCONDES FILHO, op. cit., pp. 36-37.
} 
O pesquisador, ao colocar-se no espaço liso deve fazer as observações, e o seu instrumento é a sua intuição sensível. O pesquisador deve ser objetivo, mas com uma objetividade sem aspas, pois ele se envolve, participa, é uma objetividade subjetiva. Por isso, Marcondes Filho critica trabalhos que são escritos com distanciamento, onde não percebemos o pesquisador. Não é só a gramática que busca a objetividade com aspas. É também a orientação dada ao pesquisador, pois a academia não vê com bons olhos a escrita na primeira pessoa.

O que devemos ver? Ou o que é possível ver?

Possíveis respostas são: a construção de sentido, a realização do acontecimento, a transformação incorpórea promovida pela efetivação do ato comunicacional. O sentido, contudo, não está relacionado, aqui, com significado, e sim com as sensações.

O caminho proposto por Marcondes Filho aponta para a possibilidade de sairmos de um método que nos aprisiona. Trata-se de uma saída pelos poros: "Os poros são a única coisa que podem conduzir da obscuridade à luz". ${ }^{17}$ Para explicar a idéia de poros, o autor cita Sarah Kofman.

Poros é a abertura de uma passagem num espaço caótico; ele introduz vias, cria direções possíveis, caminhos de fuga, ele vence a aporia. Poros, diz ela, dissipam a obscuridade que reina na noite das águas primordiais abrindo as vias por onde o sol pode levar à luz do dia e as estrelas são capazes de traçar o céu de rotas luminosas das constelações. É a opção para quem não pretende seguir um caminho estriado, contaminado por uma teoria imóvel, rígida, travada, mas que busca o caminho liso, aberto, indeterminado, difuso, livre. ${ }^{18}$

Os poros são a possibilidade de saída, repete Marcondes Filho, mas é uma saída que não se torna o caminho definitivo, é uma saída sempre com outras saídas. Por isso, ele não fala de métodos, mas de Metáporos (meta + poros). Poros, uma passagem, um vislumbro, um insight.

Metáporos é, pois, um procedimento. Contudo, tal procedimento reconhece os limites do ver, a impossibilidade de se chegar a um todo. O pesquisador deve ser despretensioso e reconhecer que, quando vê algo de frente, jamais, ao mesmo instante, conseguirá visualizar a parte de trás. Marcondes Filho fala de poros enquanto passagem: “construir uma passagem

\footnotetext{
${ }^{17}$ Ciro MARCONDES FILHO, Princípio da Razão Durante: por uma teoria do acontecimento em comunicação, p. 45.

${ }^{18}$ Ibid. p. 46.
} 
para o outro lado, cavar na superfície da água, no monte de grão, abrindo, no vento, atos que desfazem em seguida tudo o que acabamos de abrir." 19

Só podemos nos abrir à natureza do outro, mas este não será capturado. A meta é descrever um ato genuinamente comunicacional na medida em que eu, ao mesmo tempo, o sinto e o vivencio, permito que meus poros sejam atravessados por esse clima, esse espetáculo. Dentro de tantas possibilidades, como não se apaixonar pelo conceito de Metáporos? Contudo, não para possuí-lo, mas para vivenciar a energia de ser espectadora de algo que está vivo, pulsante, e não morto.

O grande desafio, contudo, é a capacidade narrativa do estudioso, sua habilidade em transformar, para o registro, não apenas o acontecimento como também o que o envolve, material e imaterialmente, tentando repassar para o leitor a força, o ânimo, a vitalidade, em suma: a vida do evento comunicacional. A grande inovação da proposta de Marcondes Filho é a inclusão da dinâmica no procedimento de pesquisa, fazendo com que a atividade do estudioso torne-se ágil, pontual, sincrônica com o acontecimento, gerando com isso uma destreza de pensamento, sempre em renovação. Em síntese:

Metáporo
1. Considera o movimento do mundo, que é permanente, e nossa
inserção nele (a contingência, a transitoriedade);
2. Considera o território na investigação: espaço liso (espécie de corpo
pleno sem órgãos), suporte para o emaranhado de fios, vetores, linhas,
cruzamentos;
3. Considera nosso deslocamento nele: nômade, errático, em rodeio;
4. Quanto ao olhar, à observação: da precedência à intuição sensível,
considera a atmosfera circundante; está focada na captura do processo
gerador, nas relações que constituem objetos;
5. Está à espreita do Acontecimento que pode surgir;
6. Faz um registro ou um relato como forma de efetuação mas aspirando,
como telos, que este se torne contra-efetuação, portanto saber.

\footnotetext{
${ }^{19}$ Ciro MARCONDES FILHO, Princípio da Razão Durante: por uma teoria do acontecimento em comunicação, p. 47.

${ }^{20}$ Ibid., p. 57.
} 
São com os procedimentos do Metáporo que pretendemos narrar o Educom.TV, suas curvas, seus desvios, seus poros. Não é uma descrição objetiva com aspas, afastada de alguém que consultou documentos, mas é o relato de quem vivenciou o projeto, misturou-se e esteve misturado nele. Por outro lado, continuamos pensando a Educomunicação, que não nasceu e nem morreu no Educom.TV. Ao contrário, o precedeu nas ações do movimento pupular desde os anos 60 e que continuou nos projetos implementados pelo NCE/USP, como o Educom.Centro-Oeste, o Educom.Mídias e os programas de Educomunicação do Ministério do Meio Ambiente, ou mesmo, pelo país afora, nas diversas oficinas e encontros em que educomunicadores se propõem ao diálogo.

Alice, caindo no poço da toca do coelho, pensa: "essa queda nunca teria fim? - Só queria saber quantos quilômetros já desci”. Não há fim no País das Maravilhas, há passagens, encontros. Há o outro que é o infinito e que me acolhe e, assim, continuamos a caminhar. 


\section{O CONTEXTO HISTÓRICO}

Antes de iniciar a descrição do projeto educomunicativo, abordaremos o contexto em que se operou a constituição das condições propícias para o surgimento da educomunicação no Brasil.

O contexto político que resgataremos para começar a rastrear a história da Educomunicação tem, na verdade, início durante o período de 1950-1964 e no pós 1968. Abordamos estes dois períodos por acreditar que são significativos para os pressupostos elementares ao surgimento da Comunicação Popular e, posteriormente, a Educomunicação.

\section{A repressão}

O período de quatorze anos (1950-1964) foi considerado pelo pesquisador Boris Fausto $^{21}$ como a era da polarização "capitalismo versus comunismo", com forte fase desenvolvimentista, crescimento urbano e aceleração industrial. Durante o período, houve avanço no plano social, principalmente dos movimentos sociais, surgindo novos atores, como as ligas camponesas. As mudanças que ocorreram na economia possibilitaram a ampliação no mercado para os produtos agrícolas e para a pecuária, o que acarretou a alteração na posse e na valorização da terra.

A terra passou a ser mais rentável do que no passado, e os proprietários trataram de expulsar antigos posseiros ou agravar suas condições de trabalho, o que provocou forte descontentamento entre a população rural. Além disso, as migrações aproximaram campo e cidade, facilitando a tomada de consciência de uma situação de extrema submissão, por parte da gente do campo. ${ }^{22}$

Na mesma época, cresce a mobilização de outros setores, como a dos estudantes, que passam a se articular em torno da União Nacional dos Estudantes (UNE) e radicalizam suas propostas de transformação social, passando a intervir diretamente no jogo político. Ocorrem, também, mudanças significativas no comportamento da Igreja Católica, e muitos dos seus integrantes passam a se preocupar com as camadas populares.

\footnotetext{
${ }^{21}$ Boris FAUSTO, História do Brasil, 2004.

${ }^{22}$ Ibid., p.446.
} 
A Igreja se dividiu entre diversas posições, indo do ultraconsevadorismo de bispos como Dom Geraldo Sigaud e Dom Castro Mayer às aberturas esquerdistas típicas da Juventude Universitária Católica (JUC). Tocada pelo clima de radicalização do movimento estudantil, a JUC foi assumindo posições socialistas e entrou em choque com a hierarquia eclesiástica. Dela nasceu em 1962 a Ação Popular (AP), organização com objetivos revolucionários, desligada da hierarquia. A AP participou ativamente das lutas políticas da época e foi duramente reprimida após a instauração do governo militar em 1964. ${ }^{23}$

Com a expansão econômica, pós década de 1950, o Governo toma a iniciativa de alfabetizar a população, exigência muito mais da dinâmica capitalista do que de um espírito socialista. Contudo, a proposta de alfabetização é também simultaneamente aplicada por organizações populares dentro de uma perspectiva política que buscava mudar a correlação de forças sociais e que, partindo de vários projetos políticos diferentes, utilizam alguns instrumentos comuns na área da cultura.

O primeiro instrumento para dinamizar a expansão econômica foi a alfabetização de adultos. Nesta época, buscou-se métodos rápidos e eficientes. A perspectiva progressista aliava à proposta de alfabetização a competência pedagógica e a riqueza dos meios de comunicação a uma visão política transformadora. A alfabetização foi considerada como um momento inicial privilegiado do processo de tomada de consciência. "O método desenvolvido por Paulo Freire se revela o mais adequado para preencher todas as demandas." 24

Diversos grupos, com orientações ideológicas distintas, participaram do movimento de alfabetização proposto por Paulo Freire: entidades culturais estudantis (como o Centro Popular de Cultura - CPC da UNE, e os vários CPCs estaduais), entidades estatais (prefeituras, governos de vários estados, Governo Federal, MEC), entidades religiosas (Confederação Nacional dos Bispos, que inclusive lançou o Movimento de Educação de Base (MEB), assim como entidades universitárias (como o Serviço de Extensão Universitária, (SEC), da Universidade de Recife). ${ }^{25}$

Paulo Freire, diretor do SEC de Recife, ampliou o seu projeto alfabetizador para um sistema educacional global. Ao mesmo tempo, a Igreja Católica desenvolve o seu projeto de alfabetização de adultos pelo rádio, por meio do Movimento de Educação de Base (MEB). Juntos, criou-se todo um ambiente em prol da alfabetização de jovens e adultos.

\footnotetext{
${ }^{23}$ Boris FAUSTO, História do Brasil, p.446.

${ }^{24}$ José Manuel MORAN, Leituras dos meios de comunicação, p. 80.

${ }^{25}$ MACIEL, Jarbas. Fundamentação Teórica do Sistema Paulo Freire de Educação, In: FAVERO, Osmar (Org), Cultura Popular, Educação Popular, pp. 130-131, In: MORAN, José Manuel, Leituras dos meios de comunicação, São Paulo: Pancast Editora, 1993, p. 80.
} 
O MEB começa com um projeto de alfabetização a distância, com a idéia de atingir os grupos de camponeses espalhados por todos os cantos do Brasil e, por intermédio da prática, o projeto se torna mais abrangente com uma conceituação de educação transformadora.

\begin{abstract}
A ação educadora do MEB não poderia se limitar às paredes das escolas radiofônicas. Toda a comunidade, e não só a população constituída de alunos e monitores, era responsável pela sua escola radiofônica. Nossa ação deveria ser supletiva, numa procura de fornecer os elementos para que o povo das comunidades descobrisse sua força própria de ação transformadora, os seus objetivos e os rumos a tomar, num trabalho conjunto e concreto. ${ }^{26}$
\end{abstract}

Tanto os seguidores do método de Paulo Freire para a alfabetização quanto os membros da Igreja tinham as mesmas pretensões, ou seja, pela alfabetização da leitura e da escrita, garantir a formação para a leitura de mundo, para a análise que contemplasse a crítica da realidade socioeconômica. Em 1964, o governo proíbe as experiências e mobilizações populares, como a UNE, e declara o método Paulo Freire como subversivo.

Com a postura radical tomada pelo governo e, conseqüentemente, pelos militares, surgem os grupos de oposição. A constituição brasileira de 1967 confere ao Executivo - com base no Ato Institucional número 2 (AI-2) - prerrogativas consideradas, para a época, autoritárias, ao mesmo tempo em que decreta a Lei da Imprensa, em fevereiro de 1967, e a Lei de Segurança Nacional. Estas leis garantiram ao novo presidente poderes praticamente ilimitados, o que levou a oposição a denunciar a "institucionalização da ditadura".

A completa restrição e, por que não dizer, destruição da vida política, pelo governo Castelo Branco, provocou reações de todo o tipo contra o regime militar. Antigos líderes políticos de grande expressão como Carlos Lacerda, Juscelino Kubitschek e João Goulart uniram-se na chamada "Frente Ampla", órgão de oposição extraparlamentar, para protestar. Em fins de 1967, Lacerda fez vários pronunciamentos agressivos contra o regime militar. No ano seguinte, os estudantes saíram às ruas, nas principais cidades do país, protestando contra a ditadura. Os confrontos entre a polícia e os universitários se multiplicaram, culminando, no Rio de Janeiro, com o assassinato do estudante Édson Luis. Como protesto, os estudantes promoveram, também no Rio, a célebre Passeata dos Cem Mil, a maior demonstração pública de repúdio ao regime militar.

A violência policial crescia desproporcionalmente. Tornam-se rotineiras as invasões às universidades e as prisões de estudantes. Ao mesmo tempo e inutilmente, os protestos

\footnotetext{
${ }^{26}$ MACIEL, Jarbas, op. cit., In: MORAN, José Manuel, Leituras dos meios de comunicação, São Paulo: Pancast Editora, 1993, p. 81.
} 
tentavam ecoar pelo país. A necessidade de organizar a luta levou os estudantes a rearticularem a extinta União Nacional dos Estudantes (UNE). No mês de outubro de 1968, vários estudantes se reuniram em Ibiúna, local onde muitos foram presos pela polícia.

Nesse ambiente de extrema exaltação, ocorreu o "caso Márcio", que funcionou como gota d'água para que o governo tomasse medidas enérgicas, no sentido de silenciar toda a oposição. ${ }^{27}$ Os militares, sentindo-se ofendidos, pressionaram o governo para processar o deputado Márcio Moreira Alves, mas o pedido foi negado pelo Congresso, em 12 de dezembro de 1968. No dia seguinte, o ministro da Justiça, Gama e Silva - conhecido por suas convicções conservadoras - apresentou ao Conselho de Segurança Nacional o texto do Ato Institucional $\mathrm{n}^{\circ} 5$, o conhecido AI-5, que entregou o país às forças mais retrógradas, violentas e obscurantistas de nossa história. ${ }^{28}$

Em fins de agosto de 1969, adoece gravemente o então presidente Costa e Silva, e o vice Pedro Aleixo, por desconfiança dos militares com os civis, é impedido de assumir. O poder fica a cargo de uma junta militar das três Armas.

O general Emílio Garrastazu Médici assumiu o poder exatamente no momento em que as manifestações públicas da oposição estudantil foram contidas pela repressão política, e os políticos do MDB foram silenciados pelo AI-5.

A inexistência de canais que permitissem fluir, sem problemas, as várias correntes de opinião do país, induziu alguns setores da esquerda a optarem por um caminho extremo: o da luta armada. Surgiram, então, as primeiras organizações de guerrilha urbana: a Aliança Libertadora Nacional (ALN), chefiada por Carlos Marighela (dissidente do PCB); o Movimento Revolucionário 8 de outubro (MR-8) - dia da morte de Che Guevara na Bolívia); a Vanguarda Armada Revolucionária (VAR-Palmares), liderada por Carlos Lamarca, excapitão do Exército. Segundo essas lideranças, só havia um caminho para derrubar a ditadura militar: a luta armada.

\footnotetext{
Mas nem só de luta armada vivia a esquerda brasileira naquela altura. A repressão já não distinguia quem era a favor ou não da guerrilha. Milhares de outros brasileiros sentiram o peso do estado policial sem necessariamente estarem ligados às organizações guerrilheiras. Uma direita bestializada, aquela ligada aos órgãos de repressão, tentava empalmar o poder. O triste episódio da morte do jornalista

${ }^{27} \mathrm{O}$ caso Márcio é uma referência à solicitação e à repercussão do discurso, feito na Câmara do deputado federal Márcio Moreira Alves, do MDB, que pediu ao povo para não comparecer às festividades do Dia da Independência, em sinal de protesto ao regime militar.

${ }^{28}$ Luiz KOSHIBA; Denise Manzi Frayse PEREIRA, História do Brasil, p. 335.
} 
Vladimir Herzog, no governo Geisel, foi indicador das intenções dos grupos mais radicais da direita e que durante anos comandaram a repressão. O país vivia o seu cotidiano tentando mostrar-se como um oásis de felicidade no meio de um mundo conturbado, enquanto as prisões continuavam a receber inúmeros 'cidadãos de segunda classe'. 29

Visões de mundo, concepções de organização social e formas de entender o coletivo foram perspectivas motivadoras de engajamentos, lutas, paixões, causas, sonhos e muitas, muitas mortes. Quarenta anos depois, podemos olhar para trás e pensar que tudo não passava de uma visão romântica, atos de adolescentes. Contudo, foram esses sonhos e esses mesmos atos que mudaram a história. Os que continuaram vivos não deixaram de sonhar. Ao contrário, alimentaram dia a dia a possibilidade da transformação. Porém, não mais pelas armas, mas por intermédio da educação, da cultura e da comunicação. A necessidade e o desejo da revolução continuaram na economia, nos valores, na estética e na cultura.

Segundo Antonio Candido, em O purgatório, texto do livro Tiradentes, um presídio da ditadura, devemos a essa gente intemerata a dignificação da condição humana. $\mathrm{O}$ agradecimento fica marcado na citação do poema El outro:

Nosotros, los sobrevivientes. A quienes debemos la sobrevida? Quién se murió por mi en la ergátula. Quién recibió la bala mia, la para mi, en su corazón? Sobre qué muertos estoy yo vivo, sus huesos quedando en los mios, los ojos que le arancaron viendo por la mirada de mi cara, y la mano que no es su mano, que no es ya tampoco la mia, escribiendo palavras rotas. Donde está él, en La sobrevida? ${ }^{30}$

Em sintonia com os intelectuais, segmentos da Igreja Católica e das Igrejas Evangélicas clássicas (Metodista, Luterana, entre outras) engajaram-se na luta contra a ditadura.

A Igreja apresentava-se ao mundo com a força e a energia advindas das mudanças propiciadas pelo Concílio Vaticano II (Roma, 1965), bem como dos encontros promovidos pela Conferência do Episcopado Latino Americano (CELAM) (Medelin, Colômbia - 1968 e Puebla, México - 1979). Tal tipo de engajamento institucional acabou por animar os cristãos a se confrontarem com a realidade, afirmando seus ideais de justiça, solidariedade e dialogicidade.

Segundo Pedro Gilberto Gomes, as mudanças redimensionaram o papel do leigo na organização e sua atuação na vida eclesial, como também conduziram a uma reorganização da

\footnotetext{
${ }^{29}$ FREIRE, Alípio. Olhar da memória. In.: FREIRE, Alípio; ALMADA, Izaias; PONCE, J.A. de Granville, Tiradentes, um presídio da ditadura, memórias de presos políticos, 1997, p. 39.

${ }^{30}$ Poema escrito pelo poeta cubano Roberto Fernández Retamar, em 1 janeiro de 1959. In: CANDIDO, Antonio. O purgatório, In: FREIRE, Alípio, ALMADA, Izaias; PONCE, J.A. de Granville, Tiradentes, um presídio da ditadura, memórias de presos políticos, 1997, São Paulo, Scipione, 1997, p. 15.
} 
prática evangelizadora, colocando o desafio representado pela mídia neste processo. ${ }^{31}$ É nesse contexto que, em 1969, é fundada a União Cristã Brasileira de Comunicação (UCBC), com a missão de estimular e promover a presença cristã, efetiva e profissional, nas políticas de Comunicação Social e na mídia em geral.

\section{Por uma "Leitura Crítica" da Comunicação}

A comunicação foi uma das principais preocupações dos militares. Durante a ditadura, vários projetos foram institucionalizados na linha do uso das técnicas no ensino e na qualificação de mão-de-obra especializada (como Projeto Minerva), passando o governo a investir pesado num projeto hegemônico de unificação nacional por meio das telecomunicações.

As facilidades de crédito pessoal permitiram a expansão do número de residências que possuíam televisão: em 1960, apenas 9,5\% das residências urbanas tinham televisão; em 1970, a porcentagem chegava a $40 \%$. Por essa época, beneficiada pelo apoio do governo, de quem se transformou em portavoz, a TV Globo expandiu-se até se tornar rede nacional e alcançar praticamente o controle do setor. A propaganda governamental passou a ter um canal de expressão como nunca existira na história do país. ${ }^{32}$

O pequeno resgate histórico aqui apresentado justifica-se para lembrar que foi a insatisfação de uns e o espírito revolucionário de outros que motivaram várias ações de mobilização e engajamentos na área da comunicação, sob a suspeita de que, ideologicamente, os meios de comunicação, sustentados pelo grande capital, estariam alinhados ou davam sustentação à política de controle social, responsável último pela repressão vigente.

Tal insatisfação foi capaz de embalar várias práticas no campo da educação, sempre inspiradas em Paulo Freire - neste momento no exílio - com o propósito de conscientizar as camadas empobrecidas sobre as possíveis manipulações dos meios massivos.

Retomar alguns destes fatos históricos nos ajuda a compreender o desejo de conscientização que guiaria, posteriormente, a União Cristã Brasileira de Comunicação

${ }^{31}$ GOMES, Pedro Gilberto. A comunicação cristã em tempos de repressão, In.: ALVES, Patrícia Horta. Educomunicação: a experiência do Núcleo de Comunicação e Educação, dissertação de mestrado, São Paulo, ECA/USP, 2002, p. 51.

${ }^{32}$ Boris FAUSTO, História do Brasil, p. 484. 
(UCBC) a criar um projeto voltado especificamente para promover a "leitura crítica" dos processos de comunicação, numa iniciativa de levar à população a reflexão que se fazia na Universidade e nos espaços das Igrejas.

Neste sentido, o projeto Leitura Crítica da Comunicação (LCC) -, da UCBC ${ }^{33}$, tinha como objetivo, em última análise, levar aos setores populares a discussão sobre a necessidade da democratização dos meios de comunicação de massa, a partir de sua análise. O lema era: “aprender a ler os meios para não ser dominado por eles". Já no início dos anos 80, o projeto LCC e as discussões sobre a Leitura Crítica contribuíram para a criação de um centro de difusão e de formação de comunicadores, voltados especialmente para a educação, no Serviço à Pastoral da Comunicação (SEPAC), das Edições Paulinas ${ }^{34}$.

Segundo Moran ${ }^{35}$, o projeto LCC foi uma decorrência natural de um processo de contínuas discussões sobre temas emergentes da comunicação de massa e popular, realizadas pela própria entidade por meio de seus congressos anuais (Congressos Brasileiros de Comunicação Social) ${ }^{36}$ e na Universidade, além de contar com forte apoio dos professores e pós-graduandos da ECA/USP, da Sociedade Brasileira de Estudos Interdisciplinares da Comunicação (Intercom) e do então denominado Instituto Metodista de Ensino Superior (IMS) de São Bernardo. Participaram de forma atuante do projeto LCC lideranças como Attilio Ignácio Hartmann, Ismar de Oliveira Soares, José Manoel Moran, Joana Puntel e Reinaldo Brose. O grupo contava ainda com Maria Felisminda de Rezende e Fusari e Pedro Gilberto Gomes ${ }^{37}$.

Os grupos de movimento popular passam a ser o público que o projeto queria atingir, o que exigiu a busca de uma nova metodologia capaz de ir ao encontro das necessidades dos grupos populares. Na época, a pedagogia já criticava a transmissão de conteúdos, sem que

33 Em 1980, é eleita uma nova diretoria, a partir de Congresso, contando com a participação de Paulo Freire, e que discutiu "Comunicação e Educação Popular", transformando os cursos num programa orgânico, denominado: "Projeto de Leitura Crítica da Comunicação".

${ }^{34}$ A parceria entre a UCBC e as Edições Paulinas, no contexto do engajamento cristão em torno do fenômeno comunicativo, além de possibilitar a criação de um centro de referências (o SEPAC), propiciou que a ideologia do LCC passasse a alimentar a publicação, na década de 80, de uma série de manuais que circularam pelo país, na ocasião, como os livros de Ismar de Oliveira SOARES (Para uma Leitura Crítica dos Jornais e Para uma Leitura Crítica da Publicidade) e de João Luis VON TILBURG (Para uma Leitura Crítica da Televisão).

${ }^{35}$ José Manuel MORAN. Leituras dos Meios de Comunicação, pp. 74 - 98.

${ }^{36}$ Os Congressos Brasileiros de Comunicação Social tiveram início em 1970, estendendo-se até o final dos anos 80, cada um em uma cidade diferente, sob o patrocínio de uma universidade. Ver: Pedro Gilberto GOMES, Para uma história da UCBC, memória de uma instituição cristã dedicada a comunicação dialógica e comprometida com a resistência ao autoritarismo brasileiro. São Paulo: USP/ECA, 1991. 3 v. Tese (Doutorado, ECA/USP).

${ }^{37}$ História do LCC: o contexto de sua implementação e evolução. Disponível em http://www.ucbc.org.br/associados.asp?id=1 1\&acao亏. Acesso em: 12 jul. 2006. 
estes fizessem sentido aos educandos. Conseqüentemente, a comunicação também passa a questionar o processo mecânico "emissor-mensagem-receptor". Adota-se uma postura denominada de "indutivo-dialético-popular" no tratamento dos temas ${ }^{38}$. Nesta perspectiva, a metodologia do LCC se caracterizava por motivar a participação das pessoas do grupo em formação.

O Projeto LCC surgiu num momento em que a América Latina voltava-se para o tema da educação para a comunicação. Nem todos os projetos tinham, contudo, o mesmo caráter contestador. Moran ${ }^{39}$ lembra, por exemplo, outra experiência pioneira, no período, mas que contava com expressa influência de McLuhan adotando uma perspectiva mais otimista no tratamento com os meios. A experiência era dirigida a crianças e jovens de colégios religiosos católicos. O responsável pela implantação e difusão dos primeiros trabalhos foi o pedagogo cubano, radicado em Quito, Luiz Carlos Martiz, professor de Antropologia Cultural na Universidade Central de Quito e Diretor da Oficina Nacional do Centro de Orientação Cinematográfica (CEOC).

A partir da CEOC, surge o projeto intitulado Planejamento de Niños (crianças) para Produções de Audiovisuais (PLAN-DENI), replicado no Brasil (Rio de Janeiro) sob o título de Cinema e Educação (CINEDUC). Já as experiências da Costa Rica, no final da década de 1960, são influenciadas diretamente por Antoine Vallet, autor do conceito de "A Linguagem Total". Nesse país, Francisco Gutérrez cria e coordena o Instituto Latino-americano de Pedagogia da Comunicação (ILPEC).

A 'Linguagem Total', intimamente ligada a uma concepção ufanista dos meios, decorrente das idéias de McLuhan. 'A linguagem Total' é incorporada no CREC - Centre Recherche et Communication Audio-Visual Expression de La Foi - em Lyon, dirigido pelo Pe. Pierre Babin. É um centro que se preocupa com a catequese audiovisual, com a capacidade de expressão da criança e do adulto. ${ }^{40}$

Mais alinhado à perspectiva de criticidade da UCBC, vamos encontrar, na Venezuela, o Centro al Servicio de La Acción Popular (CESAP), sob a coordenação de Mario Kaplún, e, no Chile, o Centro de Indagación y Expresión Cultural y Artística (CENECA), assim como a Fundação Educacional Roberto Bellarmino (Projeto Bellarmino), este dos jesuítas.

\footnotetext{
38 A metodologia do LCC foi objeto da tese de livre docência de Ismar de Oliveira Soares, em 1991.

${ }^{39}$ José Manuel MORAN, Leituras dos Meios de Comunicação, p. 84.

${ }^{40}$ Ibid., p. 84.
} 
Os projetos de Leitura Crítica implementados por estas instituições latino-americanas, enfatizavam pouco o lado da produção e acabavam tendo, como componente predominante, a racionalidade, a análise, o julgamento e a comparação crítica.

\begin{abstract}
O conceito de valor aparece em todos os projetos, mas com enfoques muito diferentes. No LCC há uma perspectiva ética dentro de uma teoria político-dialética. Os valores se dão num contexto de classe social, numa perspectiva libertadora, cujo modelo é o evangelho, interpretado pela Teologia da Libertação. Os valores são mais sociais do que individuais e o grupo ajuda a reforçar a consciência de classe. ${ }^{41}$
\end{abstract}

Para Moran, faltava, neste momento de mudanças, uma teoria consistente de comunicação e cultura. O próprio autor acaba por apresentar, na sua tese de doutorado, uma proposta de leituras dos meios de comunicação com o objetivo de incorporar as análises de conteúdo, da produção e da linguagem. Mas nenhuma leitura dos meios de comunicação, no Brasil, é tão seguida, estudada e analisada como foi e continua sendo o projeto LCC. Com o passar dos anos e com a incorporação do campo da Comunicação de outras perspectivas teóricas, novas propostas para a formação de leitura ou leituras dos meios de comunicação foram apresentadas. Contudo, o LCC marca uma época, principalmente pelo pressuposto emancipatório.

A UCBC, na verdade, desde sua criação em 1969 e do seu primeiro Congresso, realizado no Rio de Janeiro, em 1970, havia tomado como fundamental a reflexão sobre a Comunicação Social no contexto das relações sociopolíticas. A entidade defendia o direito de todos os segmentos sociais participarem da elaboração e execução de políticas de Comunicação que expressassem os interesses populares. ${ }^{42}$

\footnotetext{
Uma paz verdadeira não se faz sem uma comunicação autêntica e participativa. Esta foi uma das nossas conclusões. Uma ordem política, que permita o crescimento da sociedade atendendo as reivindicações daqueles a quem sistematicamente se nega o direito à voz, só é possível se entendermos que a paz social não é algo imposto através de 'pactos sociais' artificialmente arquitetados, mas o resultado de profundas mudanças estruturais. ${ }^{43}$
}

Soares e Motta defendiam que a nova ordem jurídica para o estatuto da Comunicação Social não era uma questão de supra-estrutura, ou de lei menor. Tratava-se de uma questão de direitos fundamentais dos grupos humanos. Por isso, a reflexão proposta no XIV Congresso da UCBC sobre a Comunicação Construção da Paz, para eles, transcendia os debates

\footnotetext{
${ }^{41}$ Op. cit., José Manuel MORAN, p. 161.

${ }^{42}$ Ismar de Oliveira SOARES; João Manoel MOTTA (Org.), A comunicação na construção da paz, s.d.

${ }^{43}$ Ibid.
} 
superficiais com os quais se ocupavam os políticos, intelectuais, empresários e trabalhadores do setor.

A contribuição da UCBC, para o momento, foi, portanto, a de ter refletido sobre certo imobilismo e conservadorismo que havia se instalado nas discussões sobre as políticas de comunicação. Soares era, então, presidente da UCBC e já atuava como comunicador e gestor, discutindo e defendendo a democratização dos meios de comunicação, bem como uma comunicação para a verdade e para a paz que fosse democrática e libertadora, próximas aos ideais do Movimento Popular.

\section{A Comunicação Popular}

Para a pesquisadora Cicilia Maria Krohling Peruzzo, a comunicação que se volta para as questões sociais é denominada de Comunicação Popular ou Comunicação "nos" e "com" os Movimentos Populares.

Peruzzo $^{44}$ considera que a prática da comunicação popular corresponde a todo um processo de mudança no interior das sociedades latino-americanas. Momento histórico em que se negava a plenitude da cidadania da maioria da população. São práticas que vão além das atividades que envolvem os meios comunicativos, tais como: jornais, rádio etc.

A "nova comunicação" (ou comunicação popular) representou "um grito, antes sufocado, de denúncia e reivindicação por transformações, exteriorização, sobretudo em pequenos jornais, boletins, alto-falantes, teatro, folhetos, volantes, vídeo, audiovisual, faixas, cartazes, pôsteres, cartilhas etc." 45

A comunicação popular estaria voltada para os processos realizados nas dinâmicas dos movimentos populares, de acordo com as suas necessidades, e não para o mercado editorial, radialista ou similares. Peruzzo salienta que uma das características essenciais da comunicação popular é a "participação” voltada para a mudança social.

\footnotetext{
${ }^{44}$ Cicilia Maria Krohling PERUZZO, Comunicação nos movimentos populares: a participação na construção da cidadania, pp. 114-115.

${ }^{45}$ Ibid., p. 115.
} 
Segundo a pesquisadora, no Brasil e principalmente no campo da Comunicação, os estudos sobre o popular seguiram três correntes: o popular-folclórico, o popular-massivo e o popular-alternativo. O primeiro "abarca o universo das expressões culturais tradicionais e genuínas do 'povo', presentes em manifestações folclóricas, festas, danças, ritos, crenças, costumes, objetos etc. O popular-massivo estaria relacionado com a indústria cultural e, por fim, o popular-alternativo situa-se no universo dos movimentos sociais."46

Cabe ressaltar que a nomenclatura "comunicação popular" às vezes se confunde com “comunicação alternativa" ou "comunitária". Mas podemos entender comunicação alternativa por práticas que buscaram "alternativas", como o próprio nome já diz, aos grandes meios de circulação. São exemplos de alternativos na imprensa, entre outros: Posição, Movimento, Pasquim, Coojornal, Versus, Extra. ${ }^{47}$

Eram publicações de caráter cultural, político e expressavam interesses da média burguesia, dos trabalhadores e da pequena burguesia. Eram espaços nos quais grupos de oposição em frentes políticas emitiam uma corajosa condenação ao regime político ${ }^{48}$

Segundo Peruzzo, podemos compreender por comunicação popular os processos que envolvem desde os pequenos meios de comunicação dirigida até os de comunicação grupal e também os de comunicação de massa. Porém, os veículos de expressão popular não são elaborados com metodologia uniforme, e isso fica claro nos dias atuais.

Em um primeiro momento, a comunicação popular foi identificada como uma comunicação simples, de circulação limitada, produzida quase artesanalmente por grupos populares. Também foi caracterizada como aquela que não está ligada ao tipo de instrumento utilizado, mas ao conteúdo das mensagens. Outros já afirmam que não são os meios técnicos em si que definem a comunicação popular, nem tampouco são os seus conteúdos. $\mathrm{O}$ alternativo estaria no processo de criação conjunta, no diálogo e construção de uma realidade distinta, na qual a pessoa possa ser sujeito pleno. O que torna a comunicação popular é sua

\footnotetext{
${ }^{46}$ Cicilia Maria Krohling PERUZZO, Comunicação nos movimentos populares: a participação na construção da cidadania, pp. 118-119.

${ }^{47}$ Ibid., p. 120 .

${ }^{48}$ Sobre as publicações, análise e conteúdo consultar bibliografia: MOREIRA, Sônia Virgínia, Retratos brasileiros: vinte anos de imprensa alternativa. In: Antologia do Prêmio Torquato Neto, 1985; PEREIRA, Raimundo, Vive a imprensa alternativa. Viva a imprensa alternativa", In: FESTA, Regina e SILVA, Carlos E. Lins da (Org.), Comunicação popular e alternativa no Brasil, 1986; MEDINA, Cremilda, Notas sobre o trabalho social na imprensa popular. Cadernos Intercom, 1982; CAPARELLI, Sérgio. Comunicação de massa, sem massa, 1980; e FESTA, Regina. Movimentos sociais, comunicação popular e alternativa, In: FESTA, Regina e SILVA, Carlos E. Lins da. Conforme, Cicilia Maria Krohling PERUZZO, Comunicação nos movimentos populares: a participação na construção da cidadania, p.120.
} 
inserção num contexto alternativo, caracterizado por romper a ordem do capital, integrar aquilo que o fragmenta.

Christa Berger ${ }^{49}$ identifica quatro linhas de pesquisas sobre o tema: 1) a que assume a imprensa como ponto de partida, analisando jornais operários, sindicatos, populares e alternativos; 2) a que busca uma referência teórica para descrever a comunicação popular, perpassando conceitos de classes subalternas e hegemonia; 3) a que trabalha a recepção das mensagens; e, finalmente, 4) a que relaciona a comunicação com os movimentos sociais.

Para Berger, o significado da comunicação popular está em ser um fenômeno emergente, do povo ou com ele relacionado, comprometido com a mudança social e a transformação deste em sujeito histórico.

No conjunto da produção teórica, Peruzzo identifica alguns traços comuns que se caracterizam como fundamentos da concepção de comunicação popular relacionada aos movimentos sociais. São eles: a expressão de um contexto de luta, o conteúdo críticoemancipador, o espaço de expressão democrático, o povo como protagonista e os instrumentos das classes subalternas.

\begin{abstract}
As características, na prática, acontecem inter-relacionadas, não aparecendo necessariamente ao mesmo tempo em todos os textos, mas são detectáveis na globalidade da produção acadêmica e também daquela gerada no âmbito do próprio movimento popular ou por pessoas e instituições como as organizações não-governamentais. ${ }^{50}$
\end{abstract}

a) Expressão de um contexto de luta - desenvolve-se no bojo da educação popular libertadora, ligada à luta do povo contra a degradação das condições de existência e pela defesa da vida. É um meio de conscientização, mobilização, educação política, informação e manifestação cultural do povo. É canal por excelência de expressão das denúncias e reivindicação dos setores organizados da população oprimida.

b) Conteúdo crítico-emancipador - encerra uma crítica da realidade e um anseio de emancipação, na luta por uma sociedade justa. Como produto de uma situação concreta, seu conteúdo, nos últimos anos, é essencialmente configurado por denúncias

\footnotetext{
${ }^{49}$ BERGER, Christa. A comunicação emergente, popular e/ou alternativa, 1989 p.23-24, In: PERUZZO, Cicilia Maria Krohling, Comunicação nos movimentos populares: a participação na construção da cidadania, Petrópoles, RJ, Vozes, 1998, p. 123.

50 BERGER, Christa. A comunicação emergente, popular e/ou alternativa, no Brasil, 1989, p.23-24, In: PERUZZO, Cicilia Maria Krohling, Comunicação nos movimentos populares: a participação na construção da cidadania, Petrópoles, RJ, Vozes, 1998, p. 124.
} 
das condições reais de vida, oposição às estruturas de poder geradoras de desigualdades, estímulo à participação e à organização, reivindicações de acesso e bens de consumo coletivo etc.

c) Espaço de expressão democrática - espaço de comunicação democrática, vinculada aos interesses dos segmentos subalternos da população, tanto em sua metodologia quanto em sua forma e em seu conteúdo. Contudo, a participação na comunicação popular não diz respeito unicamente à produção de meios. Ele perpassa as relações interpessoais e grupais e ali ajuda a construir a base de nova cultura política.

d) O povo como protagonista - a comunicação popular tem como protagonista o próprio povo e/ou as organizações e pessoas a ele ligadas organicamente. Neste caso, ele é visto no seu antagonismo em relação às classes dominantes, concebido como o conjunto das classes subalternas.

e) Instrumento das classes subalternas - a comunicação popular é entendida como a das classes subalternas, realizada num processo de luta de classes. Neste caso, ela é vista como oposto ao modelo massivo em poder das classes dominantes. ${ }^{51}$

Podemos dizer, então, que todo o processo político vivido pelo país, principalmente depois de 1968, com a repressão militar, com a falta de democracia e mais uma grande diferença socioeconômica, fez nascer todo um movimento denominado Comunicação Popular, que englobou o alternativo e o comunitário. Tanto as práticas da comunicação popular como o projeto LCC da UCBC nascem de pressupostos comuns que são: emancipação das classes economicamente desfavorecidas, bem como: direito à expressão, direito à cidadania e direito à luta pela democratização dos meios de comunicação de massa. Neste contexto, e com os mesmos pressupostos, surge a Educomunicação.

${ }^{51}$ Cicilia Maria Krohling PERUZZO, Comunicação nos movimentos populares: a participação na construção da cidadania, pp. 124-128. 


\section{A EDUCOMUNICAÇÃO: UM POSSÍVEL CAMPO EMERGENTE DE INTERVENÇÃO SOCIAL}

\section{A descrição do campo}

Em 1995, Ismar de Oliveira Soares, que já havia sido presidente da UCBC e atuado na comunicação popular, publica um texto reivindicando um novo profissional para a área da Comunicação Social. Segundo ele, o mercado necessitava de um novo profissional para escolas, Secretarias de Educação, centros culturais das empresas, editoras, emissoras de rádio e de TVs. Esse novo profissional seria um "gestor de comunicação educativa". 52

O artigo relata a experiência de um colégio particular de grande porte, situado em São Paulo, que havia publicado um anúncio nos principais jornais da capital, abrindo inscrições para o processo de seleção. Tal processo iria indicar o nome do novo funcionário a ser contratado pela diretoria.

O candidato, conta Soares, deveria ocupar uma função que compreenderia as interrelações de comunicação no interior da escola. A principal característica da atividade seria: definir uma política de trabalho comunicativo para todos os setores. O profissional contratado deveria, pois, cuidar da relação do colégio com os pais e com a sociedade; cuidaria também dos veículos de comunicação mantidos pelo colégio (seu boletim e seu anuário); cuidaria, ainda, da relação do colégio com a imprensa e estaria atento ao conteúdo veiculado pelos meios massivos de comunicação, para, quando oportuno, oferecer assessoria aos professores nos trabalhos de análise dos meios ou de "leitura crítica da comunicação.

Conta Soares que duzentos candidatos se apresentaram com os mais diversos perfis: jornalistas (inclusive com atuação reconhecida na grande imprensa), profissionais de relações públicas, publicitários e produtores culturais. O escolhido foi um profissional de relações públicas.

Passado dois anos, o candidato selecionado que assumira o cargo de "coordenador de comunicação" havia deixado a função, por não se adaptar ao perfil pretendido. No final do

\footnotetext{
${ }^{52}$ TECNOLOGIA EDUCACIONAL. Local: - v. 23, n. 126, set/out, São Paulo, ABT - UCBC, 1995.
} 
artigo, Soares destaca a necessidade do campo da Comunicação repensar suas práticas e sua resistência em se aproximar do mundo da Educação, ao mesmo tempo em que chama a atenção do campo da Educação para rever a sua postura frente aos processos comunicacionais. $\mathrm{O}$ artigo já era o anúncio para que os campos acadêmicos da Comunicação e da Educação pensassem ou na formação de um novo profissional ou na incorporação de uma nova disciplina nas suas graduações.

Antes mesmo da fundação do Núcleo de Comunicação e Educação (NCE-ECA/USP) em 1997, Soares já era defensor de que o campo da Comunicação se aproximasse da Educação e que esta, por sua vez, repensasse o seu olhar sobre a própria comunicação - já que esta era vista como responsável pelos meios de comunicação de massa, instrumento de manipulação e opressão. Após a fundação do NCE, Soares e uma pequena equipe de jovens pesquisadores iniciaram um trabalho de estudos considerado como de fundamental importância para a formalização do campo da Educomunicação.

O trabalho de estudo e pesquisa foi realizado junto a 176 especialistas de 12 países da América Latina. ${ }^{53}$ No relatório final, Soares conclui que há um novo campo emergente em formação, ${ }^{54}$ "ressemantizando", para designá-lo: surge o termo "Educomunicação". O relatório final da pesquisa, divulgado pela Revista Contato, editada pelo senador Artur da Távola, em Brasília ${ }^{55}$, passou a circular por meio de artigos na Revista Comunicação $e$ Educação (ECA) e em outras revistas do campo da Comunicação.

A aludida "ressemantização" refere-se à ampliação do sentido com que o termo vinha sendo usado por Kaplún e Hermosilla para designar a "educação para os meios", uma das áreas do novo campo. Documentos escritos por Mário Kaplún, em 1987, apontavam que o

\footnotetext{
${ }^{53}$ Conclusões publicadas na revista Contato. Brasília: Gráfica do Senado Federal. 1997.

${ }^{54}$ Ao término da pesquisa financiada pela FAPESP entre 1997 e 1999, Soares conclui que um novo ofício já vinha sendo exercido por um profissional diferenciado, denominado de "Edu-comunicador", e que, reconhecido esse novo profissional, se evidenciava a emergência de um novo campo: a Educomunicação. No caso, foi a prática social, e não a mera especulação teórica que apontou para emergência do novo setor: "O conceito referese a um campo emergente de intervenção social, ou seja, ao conjunto das ações próprias de programas que promovem o planejamento, a implementação e a avaliação de processos e produtos, criando e fortalecendo ecossistemas comunicativos abertos, democráticos e participativos em espaços educativos, presenciais ou mesmo virtuais, tendo como consequiência a melhoria do coeficiente comunicativo das ações educativas, incluindo, neste contexto, as relacionadas com o uso dos recursos da informação nos processos de aprendizagem. No caso, tais ações têm como fundamento a realidade das mediações culturais protagonizadas historicamente pelos sujeitos sociais, pressupondo a intencionalidade educativa do uso das tecnologias, a metodologia da ação colaborativa e a meta do pleno exercício da liberdade de expressão dos atores sociais". SOARES, Ismar de Oliveira. Metodologia de educação para a comunicação e de gestão comunicativa no Brasil e na América Latina. In: BACCEGA, M. Aparecida. Gestão de Processos Comunicacionais, São Paulo: Atlas, 2002, p. 115.

${ }^{55}$ Ismar de Oliveira SOARES, Revista Contato, Brasília, ano 1, n.2, jan/mar., 1999.
} 
pesquisador pensava na formação de um especialista que levasse a leitura crítica para o espaço da educação formal, recebendo, por analogia, o nome de Edu-comunicador ${ }^{56}$, separando o radical "Edu" da palavra "comunicação":

Ao considerar que uma formação em Educação para os Meios contribuiria poderosamente para que os licenciados em Comunicação Educativa conquistem este perfil, sugerimos que os alunos desta orientação recebam uma formação específica nesta área, já que neste caso, se trata de muito mais do que referências indispensáveis, mas de uma disciplina fundamental a formação integral dos Educomunicadores. ${ }^{57}$

No Brasil, o que marcou o termo inicialmente foi o fato de o campo da Comunicação não contar, até aquela data (final dos anos 90), com nenhuma formação específica de professores na área, como uma licenciatura. Soares, ao apresentar o termo, insere o debate sobre a necessidade de formar tal especialista para o campo da Comunicação. ${ }^{58}$

Outro fato que marcou o conceito foi sua abrangência. Segundo Soares, o novo campo emergente vai além da "educação para a recepção crítica", tornando-se propositivo: visa uma efetiva intervenção social que se configura em cinco áreas de atuação, todas unidas por uma só filosofia: a de ampliar a prática da cidadania mediante a aprendizagem sobre como aplicar a gestão participativa e democrática dos recursos da informação nos espaços educativos. No caso, cada uma das áreas volta-se para um aspecto desta proposição. São elas:

- a área da expressão comunicativa por meio do uso dos recursos da informação e das artes. Trata-se do esforço de grupos em buscar novas formas de expressão que superem a escrita. As artes corporais ou as possibilidades oferecidas pelas novas tecnologias ampliaram, substancialmente, o potencial expressivo das comunidades humanas. O que se busca, contudo, não é simplesmente a performance dos indivíduos, mas o resgate de seu poder comunicador ou de sua capacidade de expressão;

- a área da educação para a comunicação, configurada nos esforços sistemáticos de educadores, no sentido de colaborar com os usuários dos meios massivos, na formação do

\footnotetext{
${ }^{56} \mathrm{Na}$ publicação escrita por Mário Kaplún e Maria Elena Hermosilla denominada de La Educaion para los médios em La formacion del comunicador social, publicado pela Fundação de cultura universitária da Licenciatura da Ciência da Comunicação da Universidade da República do Uruguai, em Montevidéu de 1987, toda a segunda parte é dedicada a apresentar a proposta da Educomunicação e a Universidade, p.50.

57 "Al considerar que uma formación em Educación para los Medios contribuiria poderosamente a que los licenciados em Comunicación Educativa conquisten este perfil, sugerimos que los alumnos de esta orientación reciban uma formación específica em esta área, ya que em este caso, se trata de mucho más que de um aporte indispensable, sino de uma disciplina fundamental a La formación integral de los Edu-comunicadores". Mário KAPLÚN; Maria Elena HERMOSILlA, La Educaion para los médios em La formacion del comunicador social, p.56.

${ }^{58}$ A ECA/USP considera os departamentos de turismo e audiovisual - que reuniu Rádio, Televisão e Cinema como áreas da comunicação.
} 
que Paulo Freire denominou "consciência crítica", frente às mensagens editadas e veiculadas por poderosos sistemas de comunicação. Esta área também pode ser denominada como recepção ativa - classificação mais de acordo com os estudos e pesquisas de recepção;

- a área da mediação tecnológica nos espaços educativos, constituída pelos esforços no sentido de identificar a natureza da interatividade propiciada pelos novos instrumentos da comunicação e de democratizar o acesso às tecnologias, desmistificando-as e colocandoas a serviço de toda a sociedade;

- a área da gestão da comunicação nos espaços educativos, caracterizada pela abordagem sistêmica das relações entre os recursos da comunicação e as atividades humanas, garantindo o planejamento e uma implementação organizada dos recursos da informação, de modo a assegurar a eficácia na construção dos ecossistemas comunicativos ${ }^{59}$. A área da gestão da comunicação nos espaços educativos é a que garante coordenação e eficiência às demais áreas, permitindo que se obtenha visibilidade para as ações educomunicativas. Entendemos por gestão a organização de projetos e ações que busquem uma melhor comunicação interna nos espaços. Neste sentido, o gestor não tem como objetivo garantir a expressão, nem a leitura ou a mediação, mas a comunicação na busca de soluções criativas de problemas;

- a área da reflexão epistemológica sobre o campo da Educomunicação, que inclui a pesquisa e a avaliação sistemática, destinadas a compreender a complexidade das relações entre comunicação e educação.

Para Soares, a Educomunicação abrange práticas que tenham como objetivo a ampliação da autonomia dos sujeitos sociais por intermédio da comunicação ou dos recursos da informação. Neste sentido, os objetivos ou os pressupostos de todo projeto que se autodenomina educomunicativo deve, no mínimo, prever:

1) o "empoderamento" das pessoas para se expressarem e, portanto, para se apropriarem dos recursos midiáticos, a partir do seu ponto de vista e dos seus próprios projetos e interesses;

\footnotetext{
59 Segundo Soares, a expressão ecossistema comunicativo diz respeito a uma complexa teia de relações comunicativas que se dão no ambiente escolar e em outros espaços de sociabilidade. $\mathrm{O}$ autor advoga que, na perspectiva de incremento de seu ecossistema comunicativo, o ambiente escolar deveria propiciar espaços onde professores, alunos, funcionários e pais de alunos sentassem, dialogassem e discutissem os problemas da escola, da comunidade ou mesmo do Estado, de maneira franca, aberta e, conseqüentemente, democrática.
} 
2) a aplicação do diálogo entre os agentes no processo educativo, com a promoção das capacidades e habilidades preexistentes, mas pouco desenvolvidas, tendo como resultado o uso cada vez mais intenso das novas tecnologias e de novas linguagens na interação humana e grupal;

3) a formação dos agentes educacionais para a mediação social de conflitos e para a promoção de valores de solidariedade social;

4) a ampliação da capacidade dos agentes culturais para a discussão de temas transversais e próximos ao cotidiano social, tais como sexualidade, direitos, cidadania, violência, meio ambiente, entre outros;

5) a promoção da gestão participativa dos processos comunicativos.

Pressupõe, também, que novas subjetividades sejam desenvolvidas, sendo elas: a) a ampliação do coeficiente comunicativo dos sujeitos, b) o fortalecimento da noção de cidadania como meta a ser alcançada, c) a abertura para a convivência em cenários de complexidade social, e d) a motivação para o exercício do protagonismo.

Ao especificar alguns dos pressupostos defendidos pela Educomunicação, Soares lembra que sua apresentação aos cursistas, dos vários projetos desenvolvidos pelo NCE, gerou dúvidas e algumas perplexidades, pois acabou questionando algumas das atividades do sistema educativo tradicional, como a hierarquia entre professores e alunos. ${ }^{60}$

Soares sugere que o ecossistema comunicativo, uma vez implantado ou proposto nos espaços educativos, melhora a relação dos agentes que atuam na Escola. $\mathrm{O}$ aluno passa a participar de forma crítica, discutindo e refletindo sobre as suas inquietações. O professor, por sua vez, passa a ter uma relação menos hierarquizada com o aluno e também começa a conhecer e respeitar as idéias e valores deste. $\mathrm{O}$ avanço, para o ambiente escolar, estaria na capacidade do educomunicador de promover práticas que fossem consideradas comunicativas.

A Educomunicação, apesar de ter na comunicação popular sua maior referência, não restringe a sua atuação ao espaço da educação formal ou a grupos - comunidades de base ou economicamente desfavorecidas. Nesta perspectiva, a Educomunicação incorpora a

\footnotetext{
${ }^{60}$ Entrevista concedida à pesquisadora, no NCE - Núcleo de Comunicação e Educação ECA-USP em 2004, para a coletânea: Todos os Contos, realizada pela Ayvu-Etã Comunicação e Projetos da Rede ANDI Brasil, 2004.
} 
comunicação popular, mas não se restringe às características aqui apresentadas e descritas por Peruzzo.

\section{Problematizando o campo}

O campo da Comunicação está atualmente em debate. Quando o âmbito acadêmico da Comunicação se refere ao conceito de "campo", está tratando de área que preocupa a academia, com sentido suficiente para envolver a formação, a pesquisa e a extensão.

Ao discutir o conceito de "campo", Maria Immacolata V. de Lopes afirma tratar-se de um termo com sentido formal abrangente. Para ela, o "campo" consiste em um conjunto de elementos apropriados pelas instituições de nível superior, em seu trabalho de ensino e pesquisa voltado para a formação universitária. Lopes identifica, dentro do campo da Comunicação, vários subcampos, sendo eles:

1) O científico, que implica em práticas de produção de conhecimento: a pesquisa acadêmica com finalidades de produzir conhecimento teórico e aplicado (ciência básica e aplicada) pela construção de objetos, metodologias e teorias;

2) O educativo, que se define por práticas de reprodução desse conhecimento, ou seja, por intermédio do ensino universitário de matérias ditas de comunicação;

3) O profissional, caracterizado por práticas de aplicação do conhecimento e que promove vínculos variados com o mercado de trabalho.

A perspectiva administrativa do tratamento do objeto subordina-se, contudo, ao conceito de campo, nas Ciências Sociais. Maria Immacolata V. de Lopes resgata, para tanto, o conceito de Pierre Bourdieu:

Um campo é um espaço social estruturado, um campo de forças - há dominantes e dominados, há relações constantes, permanentes, de desigualdade, que se exercem no interior desse espaço - que é também campo de lutas para transformar ou conservar este campo de forças. Cada um, no interior 
desse universo, empenha em sua concorrência com os outros a força (relativa) que detém e que define sua posição no campo e, em conseqüência, sua estratégia ${ }^{61}$

A discussão do conceito de campo nos interessa para contextualizarmos a complexidade da legitimação de uma área de estudo e, ainda, para ilustrar que o próprio campo da Comunicação está se repensando com relação ao seu objeto, suas práticas e a seus métodos de pesquisa.

Pesquisadores como Lopes defendem que a comunicação já criou o seu próprio corpo teórico, com metodologias e objetos próprios. Mas isso não é consenso, inclusive entre os pesquisadores da própria comunicação ${ }^{62}$. As Ciências Sociais entendem que a comunicação mesmo naquilo que Lopes reconhece como pesquisas de base - é uma subárea de pesquisas aplicadas.

Enquanto o campo acadêmico da Comunicação estava se formando, no início da década de 1970, no Brasil, já existiam comunicadores que atuavam na comunicação popular, tanto como jornalistas e radialistas graduados ou como profissionais credenciados pelos órgãos responsáveis da época, sem terem a graduação acadêmica, ou seja, a comunicação popular independeu da consolidação do campo acadêmico.

Podemos dizer, então, que o conceito de campo, tratado atualmente na Comunicação, serve para dinamizar os debates com o objetivo de identificar o objeto de estudo do campo, bem como os referenciais teóricos e as metodologias. Entretanto, há confusão quando usado para delimitar uma área de atuação.

\footnotetext{
${ }^{61}$ Pierre Bourdieu apud. Maria Immacolata Vassalo de LOPES; Raúl Fuentes NAVARRO (Comps), Comunicación camp e objeto de estúdio: perspectivas reflexivas latino-americanas, 2001.

${ }^{62}$ Sérgio Capparelli e Ida Regina C. Stumpf lembrarm, em artigo publicado em 2001, que, quando analisamos o início da consolidação do campo acadêmico dos estudos de comunicação no Brasil, um fator que devemos levar em consideração é a origem dos programas de mestrado e doutorado no país, surgidos em áreas afins. Entre eles estão o da Pontifícia Universidade Católica de São Paulo (PUC-SP) e o da Universidade Federal do Rio de Janeiro (UFRJ), por exemplo, que nasceram no curso de Letras, com programas de pós-graduação em Literatura. O programa da Universidade de São Paulo (USP) se organizou de forma departamental, no início dos anos de 1970, com mestrado e doutorado em jornalismo, publicidade, produção editorial etc. Para Capparelli e Stumpf, a origem literária dos dois primeiros programas, aqui citados, parece ter influenciado fortemente as linhas de pesquisa e as interfaces da comunicação com outras áreas das ciências humanas. Em tal contexto, os temas pesquisados giram em torno da semiótica, literatura, televisão, jornalismo, artes, educação, entre outros. A comunicação popular, por exemplo, poderia se tornar um dos temas de interesse.
} 
A comunicação popular, por exemplo, já possuía práticas legitimadas pelos seus pares no seu início, mesmo contando predominantemente com "comunicadores populares", ou seja, aqueles não formados pela academia. O mesmo vale para a Educomunicação. Logo, usaremos o conceito de campo emergente proposto por Soares para delimitar uma área de práticas e, principalmente, de projetos para assim estabelecer a discussão e o debate.

“Campo", então, será tratado aqui para delimitar uma área com cinco tipos de ações organizadas em subáreas de intervenção como descreve Soares. São intervenções que ocorrem dentro e fora da academia, dentro e fora da educação formal, em diferentes espaços, incluindo o espaço das políticas públicas (como os trabalhados pelo MEC e pelo Ministério do Meio Ambiente), da atuação da mídia (educação informal), da ação dos centros culturais e das organizações não-governamentais, bem como, igualmente, os espaços das comunidades economicamente desfavorecidas. 


\section{MATRIZES EPISTEMOLÓGICAS: A EMANCIPAÇÃO E A DIALÉTICA DO ESCLARECIMENTO}

Teoria, na Grécia Antiga, significava especulação ou vida contemplativa. Aristóteles identificava teoria como "bem-aventurança", ${ }^{63}$ No presente trabalho, faremos referência à teoria como possibilidade de reflexão, observação, análise e sistematização. Ao mesmo tempo, vamos considerá-la como possibilidade de um pensar sobre sistematizado.

Dedicamos a esta reflexão epistemológica dois capítulos: o presente e o próximo. Neste, vamos ao encontro de pesquisadores que refletem sobre a Comunicação Popular e, a partir destes, sobre a inter-relação "Comunicação/Educação". Temos como objetivo dar continuidade à reflexão iniciada no capítulo anterior em torno da Educomunicação como campo emergente.

Para tanto, primeiramente percorremos caminhos já trilhados por outros: Ismar de Oliveira Soares, Mário Kaplún e Paulo Freire. O olhar atento busca compreender o que significa o "processo" e, principalmente, a "emancipação". Posteriormente, visitaremos especialmente Theodor W. Adorno, Marx Horkheimer, Martin Buber, Emmanuel Lévinas e Ciro Marcondes Filho. Voltaremos para uma nova proposta de observação do campo.

Soares dá o tom inicial da nossa reflexão. É a partir dele que fomos buscar e reconhecer outros autores. Soares define a Educomunicação como:

\footnotetext{
Um conjunto das ações inerentes ao planejamento, implementação e avaliação de processos, programas e produtos destinados a criar e a fortalecer ecossistemas comunicativos em espaços educativos presenciais ou virtuais, assim como melhorar o coeficiente comunicativo das ações educativas, incluindo as relacionadas ao uso dos recursos da informação no processo de aprendizagem através do diálogo franco e aberto. ${ }^{64}$
}

O levantamento seguinte tem o objetivo de refletir sobre as ações, os processos, o planejamento, o ecossistema comunicativo e, principalmente, o pressuposto que sustenta a Educomunicação no seu início: a emancipação.

\footnotetext{
${ }^{63}$ Teoria, In: ABBAGNANO, Nicola, Dicionário de filosofia, São Paulo, Martins Fontes, 2007, p. 1122.

${ }^{64}$ SOARES, Ismar de Oliveira, Gestão comunicativa e educação: caminhos da educomunicação, Comunicação \& Educação, São Paulo, 23: 16 a 25, janeiro/abril, 2002, p. 24.
} 


\title{
1. Mário Kaplún - O comunicador popular
}

$\mathrm{Na}$ América Latina, Mário Kaplún ${ }^{65}$ é considerado como fundador da área da Comunicação Popular. O jornalista e também educador foi o responsável por criar o projeto denominado Cassete Fórum, que teve por objetivo usar a comunicação, bem como os meios, para a organização popular ${ }^{66}$. A proposta não era a de produzir programas para serem simplesmente veiculados na programação comercial, mas, sim, a de contribuir com a formação da comunidade para a emancipação. A motivação e a inspiração vinham de Paulo Freire.

\begin{abstract}
De certo modo, pode-se dizer que é um modelo gestado na América Latina. Mas recebeu valiosas contribuições de pedagogos e sociólogos europeus e norte-americanos. Na nossa região, Freire e outros educadores imprimiram com clareza a orientação social, política e cultural e a elaboraram como uma 'pedagogia do oprimido' como uma educação para a democracia e um instrumento para a transformação da sociedade. ${ }^{67}$
\end{abstract}

No início do livro Una pedagogía de la comunicación - el comunicador popular, Mário Kaplún afirma que quando fazemos Comunicação Educativa - termo utilizado por ele para definir também comunicação popular em processos educativos - estamos sempre buscando, de uma forma ou de outra, um resultado formativo.

A produção da mensagem, na perspectiva de Kaplún, tem por objetivo que os destinatários tomem consciência da sua realidade, para que se suscite a reflexão. Trata-se de gerar a discussão, ou seja, discutir como processo de formação e transformação. Neste sentido, os meios de comunicação são concebidos como instrumentos para uma educação popular, como alimentadores de um processo educativo transformador.

$\mathrm{Na}$ visão de Kaplún, cada tipo de educação tem o seu correspondente em uma determinada concepção e também em uma determinada prática de comunicação. Por isso, ele

\footnotetext{
${ }^{65}$ Mário Kaplún, comunicador Uruguaio, nascido na Argentina, começa a sua produção radiofônica aos dezenove anos escrevendo roteiros. Após a década de 1960, passa a produzir programas para a televisão. Tornase conhecido na América Latina por seu trabalho radiofônico chamado "Cassete Fórum" e principalmente pelo livro "O Comunicador Popular". É considerado por Soares como precursor da Educomunicação.

${ }^{66}$ Entendemos o termo "popular" enquanto grupos organizados, comunidade de bairro, associações e sindicatos ligados à classe trabalhadora.

67 "En cierto modo, se puede decir que es um modelo gestado en América Latina. Auque recibió valiosos aportes de pedagogos y sociólogos europeos y norteamericanos, en nuestra región Freire y outros educadores Le imprimen su clara orientacíon social, política y cultural y La elaboran como uma 'pedagogía Del oprimido', como uma educación para La democracia y um instrumento para La transformación de La sociedad." Mário KAPLÚN, Una pedagogia de La comunicación - El comunicador popular, p. 45.
} 
estudou a relação das concepções consideradas fundamentais e as subdividiu em duas categorias denominadas de: exógena e endógena.

a) Modelo exógeno: trabalha a educação com ênfase nos conteúdos e nos efeitos. A relação é: educação igual objeto; b) Modelo endógeno: trabalha com ênfase nos processos. A relação se estabelece entre os educandos, que são ao mesmo tempo considerados sujeitos, e os educadores.

A educação "a" - modelo exógeno - enfatiza os conteúdos e corresponde à educação tradicional. Baseia-se na transmissão de conhecimentos e valores de uma geração a outra, do professor ao aluno, da elite instruída às massas, ao grande grupo de pessoas que não possuem conhecimento sistematizado. A Educação com ênfase nos efeitos, ou a também chamada "engenharia do comportamento", consiste, essencialmente, em "moldar" a conduta da pessoa com objetos previamente estabelecidos.

A Educação "b" - modelo endógeno - com ênfase nos processos, destaca a importância do processo de transformação da pessoa e das comunidades. Não se preocupa tanto com o conteúdo que é comunicado, nem com os efeitos, no que diz respeito ao comportamento, mas se preocupa com a interação dialética entre as pessoas e a realidade, com o desenvolvimento de suas capacidades intelectuais e da consciência social. Por isso, o seu nome é "processual".

Kaplún compara três modelos educacionais com três formas de conceber a comunicação. Para ele, assim como existiu a Educação Bancária, existe também a Comunicação Bancária, que concebe o processo comunicacional como transmissão de informação - que é o velho e conhecido esquema da Comunicação: Emissor (E) que envia a sua mensagem $(\mathrm{M})$ a um receptor $(\mathrm{R})^{68}$.

A primeira, então, é a comunicação bancária. A segunda comparação foi realizada entre a Educação dos Efeitos e a Comunicação Persuasiva, comunicação sedutora, própria da publicidade. Nesta segunda perspectiva, o comunicador é, para Kaplún, uma espécie de arquiteto da conduta humana.

\footnotetext{
${ }^{68}$ Os pressupostos aqui apresentados foram publicados por Kaplún pela primeira vez em 1985. Na época da publicação, era relevante marcar as diferentes concepções de comunicação.
} 
O terceiro modelo, denominado endógeno, está totalmente focado na pessoa e enfatiza o processo. Trata-se de comunicação processual, com foco no processo e não no produto. Este modelo é fundamental para entender a comunicação popular, pois é fundamentado basicamente em Paulo Freire e denominado também "educação libertadora" ou transformadora: ação $\rightarrow$ reflexão $\rightarrow$ ação.

Baseado no livro de Paulo Freire Pedagogia do oprimido, o terceiro modelo analisado, endógeno, tem como pressuposto central a educação para a democracia. Tal modelo também pode ser capaz de se tornar um instrumento para a transformação da sociedade. Suas bases são a práxis, a "reflexão e a ação do homem sobre o mundo para transformá-lo." 69

O objetivo da concepção apresentada acima é assumidamente de formação e transformação. Em termos de educação, o pressuposto é o seguinte: um educador, que é considerado educando, com um educando, que é considerado educador. Kaplún, assim como Freire, acreditava que ninguém se educa sozinho: "os homens se educam entre si, mediados pelo mundo, e essa trajetória na qual os homens se educam entre si é precisamente o processo educativo." ${ }^{70}$ Desta forma, tanto a educação como a comunicação ocorrem em grupo.

A ênfase no processo significa ver a educação como um desenvolvimento permanente, no qual o sujeito vai descobrindo, elaborando, reinventando, fazendo do conhecimento algo seu. Um processo de "ação - reflexão - ação" que o educando produz a partir de sua realidade, a partir de sua experiência, desde sua prática social, juntamente a todos os outros que participam do processo.

Os pressupostos da educação processual tiveram em Paulo Freire a sua fundamentação teórica e principalmente ideológica. Por isso, o papel do educador, na educação processual, é acompanhar o educando, estimular o processo de análise e reflexão, não só para facilitar, mas também para aprender e construir juntos. $\mathrm{O}$ mesmo ocorre no comunicador popular, que deve acompanhar o processo, estimulando e provocando a crítica.

A estratégia utilizada ou o objetivo na construção do planejamento é a "problematização" que deve auxiliar a pessoa a desmistificar sua realidade, tanto física quanto

\footnotetext{
${ }^{69}$ Cabe comentar que esse também é o pressuposto central para Soares: por meio da reflexão e principalmente da capacidade de ação, o ser humano pode transformar o meio ao qual ele pertence.

${ }^{70}$ Mário KAPLÚN, El comunicador popular, p. 45.
} 
social. O comunicador popular deve ter sempre presente a idéia de que o seu papel é o de estimular, problematizar, e não apenas executar a elaboração de um programa radiofônico.

A proposta na perspectiva processual é “aprender a aprender", para que o educando consiga refletir sobre as coisas por si mesmo, para que ele consiga superar as constatações meramente empíricas e imediatas das práticas que o rodeiam (consciência ingênua). É uma tentativa de fazer com que o educando consiga desenvolver a sua própria capacidade de deduzir, relacionar e elaborar sínteses (consciência crítica).

O modelo apresentado por Kaplún para a Comunicação Popular tem sua base na participação ativa do sujeito no processo educativo e também apresenta a perspectiva de formar para a participação social. A aprendizagem, para o autor, ocorre justamente na participação, no envolvimento e na investigação.

O processo deve contar com: fazer perguntas, buscar respostas, problematizar e, principalmente, problematizar-se. "A aprendizagem ocorre no vivido, no que é recriado, no que se reinventa, e não somente no que se lê e se escuta [...]. A aprendizagem somente ocorre quando é processual e quando também há gestão dos educandos". 71

Outra característica da educação processual consiste no modo como o "erro" é tratado. Este não é excluído, não precisamos vê-lo como falha (erro). Ele pode ser assumido como uma etapa necessária na busca, no processo que procura a verdade. Desta forma, não há propriamente o erro, mas a aprendizagem. É importante assumir o "erro" como força geradora, problematizadora.

O educando, refletindo e agindo, participa do processo para se formar. Contudo, o objetivo não é expor ao sujeito-educando o que o faz acrítico, alienado na sua visão de mundo de dominado.

O processo, entretanto, não oculta as contradições entre a visão de mundo e a outra perspectiva, democrática e libertadora, de cuja construção participa. "Para que haja um processo de transformação real, é necessário que os estereótipos e os hábitos do homem dominado aflorem a sua consciência, e ele vá, pouco a pouco, revisando-os criticamente". ${ }^{72}$

\footnotetext{
${ }^{71}$ Mário KAPLÚN, El comunicador popular, p. 46.

${ }^{72}$ Ibid., p. 47.
} 
A educação nesta perspectiva nunca é individual, mas sempre grupal. "Ninguém se educa sozinho", mas por experiências compartilhadas, na integração com os outros. Este tipo de educação pode até utilizar recursos audiovisuais ou tecnológicos. Mas não simplesmente para reforçar conteúdos, e sim para problematizar e estimular as discussões, os diálogos, as reflexões e, acima de tudo, a participação.

As metas, nos níveis psicossociais e culturais da Comunicação Popular, são:

- Favorecer a tomada de consciência do educando em relação a sua própria dignidade, seu valor como pessoa;

- Ajudar o sujeito da classe popular a superar seu "sentimento apreendido" de inferioridade, recompondo sua auto-estima e recuperando a confiança em suas capacidades criativas.

É uma educação comprometida com o social, principalmente comprometida com os excluídos, e que se propõe a contribuir com a libertação destes. Sua mensagem central é a liberdade essencial que todo homem tem que realizar. O seu objetivo é de que o sujeito pense e que esse pensar o leve a transformar a sua realidade.

A educação sempre ocorre em grupo. Educar em grupo, na perspectiva processual, não significa que o educador não deva passar informações por ele adquiridas. $O$ educador popular deve passar as informações sempre que for necessário, mas problematizando o processo.

As informações sempre devem responder a uma prévia problematização, a uma necessidade sentida pelo grupo, a uma pergunta formulada pelos participantes, a uma busca, a uma inquietação.

Se a inquietação não existe, a primeira tarefa do educador popular é despertá-la, fazer com que as perguntas surjam. O papel do educador popular é problematizar. Somente assim a informação oferecida por ele surtirá efeitos. Sendo assim, o grupo vai incorporar as perguntas e as respostas, fazendo-as suas.

Na Comunicação Popular ou na educação processual, o importante não é a produção com os meios de comunicação, mas a riqueza do processo vivido em torno da produção, do debate e principalmente do diálogo. Para Kaplún, "somente o diálogo comunica." 


\section{A comunicação em Kaplún}

No princípio, eram chamados somente de "mass media”, meios massivos ou de massas. Posteriormente, para uma legitimação e afirmação de seu prestígio, eles, os meios, por intermédio dos seus dirigentes, se autodenominaram "meios de comunicação social" ao se apropriarem do termo comunicação. ${ }^{73}$

Segundo Kaplún, foram os norte-americanos (grandes propulsores dos estudos da Comunicação nos anos 40 e 50) os responsáveis pelo equívoco que dominou o entendimento do fenômeno representado pela presença dos meios de comunicação social na sociedade.

Comunicação para o autor argentino significa mais que "meios de difusão", funcionando num mercado de distribuição de bens simbólicos, entretenimento e informações. Designa o communis, isto é, o colocar algo "em comum". A palavra tem, para ele, a mesma raiz de "comunidade", de "comunhão", expressando algo que se compartilha, ou se vive em comum.

Kaplún denúncia que a forma de operar os meios se converteu em modelo referencial, em paradigma de comunicação Para estudá-lo, foi construída toda uma Teoria da Comunicação que se centrava exclusivamente na transmissão de sinais de mensagens. Por conseqüência, ao invés de partir das relações humanas, foi a técnica, a engenharia, a eletrônica e as poderosas empresas proprietárias dos meios que impulsionaram a forma de conceber a comunicação (o paradigma funcionalista).

Segundo Kaplún, a causa última para a redução do conceito de comunicação à sua funcionalidade é, na verdade, o caráter autoritário e hierárquico de nossa sociedade. A relação “emissor - mensagem - receptor" descreve uma forma que é hegemônica e considerada correta, ao mesmo tempo em que é uma realidade permanente no centro da nossa sociedade autoritária e estratificada, constituindo-se como manifestação de uma dada cultura.

Sendo assim, é no esquema herdado da matemática (emissor - mensagem - receptor) que se comunica a maior parte das pessoas que mantêm relações assimétricas: o chefe com seus subordinados, o empresário com os trabalhadores, o oficial com os soldados, o professor

\footnotetext{
${ }^{73}$ Mário KAPLÚN, El comunicador popular, p. 54.
} 
com os alunos, o pai de família com seus filhos, o governador com os governados, o grande jornal com seus leitores, o rádio e a televisão com seus usuários, a classe dominante com a dominada e as grandes potências com os povos do Terceiro Mundo. ${ }^{74}$

Os setores populares, no entanto, não querem continuar sendo meros ouvintes no mercado de trocas simbólicas. Eles desejam falar e ser ouvidos, almejam ser interlocutores: "No fundo, das concepções de comunicação apresentadas há uma questão básica enfrentada pela humanidade que é definir o que entendemos por comunicação. Equivale a dizer em qual tipo de sociedade queremos viver" 75

Em El Comunicador Popular, Kaplún ilustra como entende a dicotomia entre a comunicação funcionalista e a comunicação dialógica ${ }^{\mathbf{7 6}}$ :

\begin{tabular}{|ll|}
\hline Comunicação dominadora & Comunicação democrática \\
Monólogo & Diálogo \\
Poder & Comunidade \\
Vertical & Horizontal \\
Unidirecional & De dupla via \\
Monopolizada & Participativa \\
Concentrada nas minorias & A serviço das maiorias \\
\hline
\end{tabular}

Para Kaplún, todo receptor é um emissor ou emirec ${ }^{77}$. Todo ser humano está dotado e tem faculdades para ambas as funções (emitir e receber) e tem o direito de participar do processo de comunicação, atuando alternativamente como emissor e receptor.

Kaplún defende que o comunicador popular deve também conhecer a linguagem dos meios para poder usá-los, possibilitando, assim, uma voz ativa aos educandos ou à

\footnotetext{
${ }_{75}^{74}$ Cf. Mário KAPLÚN, El comunicador popular, 2002.

${ }^{75}$ Ibid., p. 54

${ }^{76}$ Esquema montado por Mário Kaplún na obra El comunicador popular para ilustrar a comunicação dominadora em contraposição a defendida por ele: a democrática.

${ }^{77}$ Termo cunhado pelo canadense Jean Cloutier. Mário KAPLÚN, El comunicador popular, p. 59.
} 
comunidade. O comunicador popular, na perspectiva aqui apresentada, deve conhecer os meios, saber utilizar a linguagem, conhecer os processos da educação popular e, sobretudo, saber em qual sociedade vive e, principalmente, em qual sonha viver.

Mario Kaplún, ao escrever o livro, O Comunicador Popular contribuiu para que os comunicadores na América Latina, em um contexto histórico aqui já apresentado, tivessem em mãos os pressupostos sistematizados da educação processual para trabalharem com comunidades.

É inegável a contribuição de Kaplún para os comunicadores populares. Rever seus caminhos nos auxilia a continuar a caminhada. Por isso, vamos a Freire para compreender como, por meio da educação processual, podemos conquistar a emancipação.

\section{Paulo Freire: consciência e emancipação}

Os primeiros trabalhos de Paulo Freire tinham como proposta a emancipação por meio da educação, e este foi o pressuposto fundante do método para a alfabetização de jovens e adultos: "alfabetizar para ler o mundo." 78

\footnotetext{
${ }^{78}$ Dados biográficos de Paulo Freire contam que ele era formado em Direito. Contudo, após a sua primeira causa como advogado, Freire desiste da carreira e se dedica ao magistério, tornando-se professor de Língua Portuguesa no Colégio Oswaldo Cruz, o mesmo que estudou durante a sua formação no secundário em Recife. Em 1947, quando foi convidado para trabalhar no setor de Educação e Cultura do SESI, fez contato com a educação de adultos trabalhadores, sentindo de perto os problemas da educação ou da falta dela no Brasil. Com doutorado em Filosofia e História da Educação, defende a tese intitulada Educação e atualidade brasileira, o que garante a sua posse como professor na Universidade do Recife, em 1961. Freire extrapola a área acadêmica e institucional e exerce um engajamento nos movimentos de Educação Popular. Torna-se, então, fundador do Movimento de Cultura Popular (MCP) do Recife. A convite do então Ministro da Educação, Paulo de Tarso Santos, vai para Brasília trabalhar no planejamento de uma campanha nacional de alfabetização de jovens e adultos. A atividade é que faz nascer, sob sua coordenação, o Programa Nacional de Alfabetização. Freire teve fortes ligações com a Igreja e principalmente com a Teoria da Libertação. Trabalhou no Conselho Mundial das Igrejas, em Genebra, na Suíça, como consultor no departamento de Educação. Lá, colaborou nos percursos de uma educação para a paz e para a libertação dos processos opressores a que estavam submetidos os povos de países atingidos por guerras, crises econômicas e ditaduras militares. Em 1980, ao retornar ao Brasil, foi convidado pelo Prof. Ismar de Oliveira Soares para participar do Congresso Brasileiro de Comunicação Social que a UCBC realizou no campus do Instituto Metodista de Ensino Superior, passando a exercer influência decisiva no projeto de Leitura Crítica da Comunicação (ver: Jaime José ZITKOSKI, Paulo Freire \& educação, pp. 89-98).
} 
Segundo Freire, a primeira condição para que um ser possa assumir um ato comprometido está na sua capacidade de agir e refletir. É preciso que sejamos capazes de, estando no mundo, nos localizarmos nele.

Saber que, se a forma pela qual está no mundo condiciona a sua consciência deste estar, é capaz, sem dúvida, de ter consciência desta consciência condicionada. Quer dizer, é capaz de intencionar sua consciência para a própria forma de estar sendo, que condiciona sua consciência de estar. ${ }^{79}$

Mas a capacidade de refletir e agir sobre o mundo não está presente no ser. Este não poderá transpor os limites que lhe são impostos pelo próprio mundo, acarretando uma impossibilidade do compromisso. É a tomada de consciência que possibilita o ser a pensar e a agir sobre sua realidade concreta.

“A imersão na realidade, da qual o ser não pode sair nem 'distanciar-se' para admirá-la e assim transformá-la, faz dele um ser 'fora' do tempo ou 'sob' o tempo ou, ainda estar num tempo que não é seu. O tempo para tal ser 'seria' um perpétuo presente, um eterno hoje". ${ }^{80}$ Logo, é a consciência, por intermédio da capacidade de refletir e agir, que possibilita o ser de "estar" no mundo bem como a capacidade de se distanciar e de "olhar" para esse mesmo mundo.

Somente um ser que é capaz de sair de seu contexto, de 'distanciar-se' dele para ficar com ele; capaz de admirá-lo para, objetivando-o, transformá-lo e, transformando-o, saber-se transformado pela sua própria criação; um ser que é e está sendo no tempo que é o seu, um ser histórico, somente é capaz, por tudo isso, de comprometer-se. ${ }^{81}$

É preciso, então, saber distanciar-se para olhar o mundo e daí tomar consciência deste. O ser, em Freire, é um ser concreto. É aquele com capacidade de atuar, de operar, de transformar a realidade. É isso que o faz um ser concreto, ser da práxis, um sujeito sempre condicionado pela realidade em que está, pois em Freire não há "homem sem mundo, nem mundo sem homem".

É a realidade que condiciona o homem, e este, por sua vez, cria e condiciona a realidade. É na experiência histórica que o homem tem a possibilidade, segundo o ponto de vista de Freire, de observar os obstáculos e superá-los. O homem, nesta perspectiva, é compreendido como um ser histórico capaz de interagir, pensando e atuando ao mesmo tempo.

\footnotetext{
${ }^{79}$ Paulo FREIRE, Educação e mudança, p. 16.

${ }^{80}$ Ibid., p. 16.

${ }^{81}$ Ibid., p. 17.
} 
...se, num momento da experiência histórica dos homens, os obstáculos ao seu autêntico atuar e pensar não são visualizados, em outros, estes obstáculos passam a ser percebidos para, finalmente, os homens ganharem com eles sua razão. Os homens alcançam a razão dos obstáculos na medida em que sua ação é impedida. É atuando ou não podendo atuar que se lhes aclaram os obstáculos à ação, a qual não se dicotomiza da reflexão. ${ }^{82}$

Freire acredita que o ser humano com capacidade de afastamento histórico, ao se reconhecer na história como parte dela, torna-se capaz de pensar e atuar. Mas quando impossibilitado de atuar e, principalmente pela frustração de não poder intervir, acaba por comprometer-se. É o reconhecimento da contradição na humanidade, associado à impossibilidade de intervenção, que promove, segundo Freire, a indignação e, conseqüentemente, o compromisso.

Compromisso com quem? Com a sua história e principalmente com a classe social de que provém, a qual pertence em que é formado. Entretanto, não basta que o sujeito se reconheça como um ser pensante e que age. Torna-se fundamental captar as contradições da própria humanidade com relação às injustiças para, então, exercer o comprometimento.

O ser humano é um ser pensante e com capacidade para agir, interferir e principalmente mudar. No decorrer da história, devemos reconhecer as contradições e, em primeiro lugar, as injustiças, para, assim, partir da indignação até alcançar o comprometimento com a humanização do homem.

A tomada de consciência e o comprometimento com a humanização do próprio homem, em Freire, podem ocorrer por intermédio da educação. Sendo a raça humana inacabada ou inconclusa, ela necessita da educação para progredir.

Segundo Freire, eis a raiz da educação: o homem freqüentemente realizando perguntas sobre si mesmo como: quem eu sou? Para onde vou? Assim, parte em busca das respostas e reflete sobre as perguntas na "Razão Durante" dessa procura".

A educação é uma busca, porque o homem sabe-se inacabado. Porém, o homem deve ser sujeito dessa busca e não objeto dela. Por isso, seguindo a perspectiva apresentada acima, ninguém se educa sozinho. E, para Freire, o homem, não sendo sozinho, é comunicação.

\footnotetext{
${ }^{82}$ Paulo FREIRE, Educação e mudança, p.18.
} 
Ainda segundo o autor, ninguém liberta ninguém; por outro lado, ninguém se liberta sozinho. "Os homens se libertam em comunhão". 83 A libertação não é, neste modo de ver, algo somente intelectual. Também é ação, ou seja, está na capacidade de pensar e agir para intervir. O pensar está fortemente associado à reflexão, e esta ocorre pelo diálogo crítico e libertador. O oprimido precisa se reconhecer como homem, "na sua vocação ontológica e histórica de ser mais (sic)". ${ }^{84}$

Libertar-se é saber pronunciar o mundo, é vivência da condição humana, é o Ser, ser protagonista de sua própria história. A Educação popular traz consigo o projeto que almeja: a libertação pela humanização. Reflexão - ação: é isto que Freire nomeia como práxis. Não é um projeto para o futuro, mas algo que se concretiza no cotidiano, ou seja, no dia a dia, pelo conhecimento crítico e na alegria de viver. Nesta perspectiva, a Educação Popular tem como pressuposto a emancipação para a humanização no contexto social e em uma sociedade dividida em classes.

\section{Emancipação}

A palavra "emancipação" está relacionada, no dicionário, ao processo de libertação da humanidade em relação a qualquer tipo de vínculo, seja religioso, político ou econômico etc. que impeça sua plena realização ${ }^{85}$. Segundo Pogrebinschi, ${ }^{86}$ a origem do conceito, em sua formulação latina, emancipatio, deriva de "manu capere", enquanto ato jurídico por meio do qual o "paterfamilia" da República Romana tinha autorização para libertar seu filho do pátrio poder. $^{87}$

Se na organização republicana de Roma a autoridade que proporcionava a emancipação era o "paterfamilia", na Idade Média ela passa a ser o direito emanado do

\footnotetext{
${ }^{83}$ Paulo FREIRE, Pedagogia do oprimido, p. 58.

${ }^{84}$ Ibid., p.59.

${ }^{85}$ Emancipação: In: ABBAGNANO, Nicola, Dicionário de filosofia, São Paulo, Martins Fontes, 2007, p. 362.

${ }^{86}$ Thamy Pogrebinschi. apud. Maria do Amparo Caetano FIGUEIREDO, Dialogando com Freire e Boaventura sobre emancipação humana, multiculturalismo e educação popular, 2005.

${ }^{87}$ Maria do Amparo Caetano FIGUEIREDO, Dialogando com Freire e Boaventura sobre emancipação humana, multiculturalismo e educação popular. Texto apresentado no V Colóquio Internacional Paulo Freire, Recife - 19 a 22 - setembro, 2005, p. 3.
} 
Estado. Há, portanto, a emancipação no campo público, político. ${ }^{88} \mathrm{O}$ Estado passa a representar, na significação do termo, o agente emancipatório. Não é mais o "paterfamilia" quem emancipa, e sim o Estado.

Entretanto, a partir do século XIX, o Estado passa a ser o objeto que o ser humano quer: a emancipação. Pois o mesmo se torna a origem da opressão. É Marx que estabelece a distinção entre os conceitos de emancipação política e emancipação humana.

A emancipação política se configurou pela superação da forma de sociabilidade feudal, em que o modo de produção estabelecia uma desigualdade jurídica e política explícita entre as classes sociais. Portanto, a emancipação política, não extingue, antes solidifica a desigualdade social. Não obstante, para Marx, a emancipação política para o seu contexto, representa um grande progresso. ${ }^{89}$

Segundo Maria do Amparo Caetano Figueiredo, o marxismo herda um conceito mais fértil e mais amplo de emancipação. Trata-se de uma emancipação humana geral, enquanto a mais elevada expressão das potencialidades humanas. Para Marx, a emancipação humana só se realiza quando o homem reconhece e organiza as suas próprias forças como forças sociais, deixando, desta maneira, de separar de si a força social sob a forma de força política. ${ }^{90}$

Neste ponto de vista da emancipação, encontramos aproximações ao pensamento freiriano. Pois o ser, em Freire, só se emancipa no pensar e no agir em comunhão, não ocorre no indivíduo isolado, e sim na sociedade.

O termo é retomado pelo projeto do Iluminismo na perspectiva de se libertar de si mesmo, ação do próprio sujeito.

\footnotetext{
${ }^{88}$ Maria do Amparo Caetano FIGUEIREDO, Dialogando com Freire e Boaventura sobre emancipação humana, multiculturalismo e educação popular. Texto apresentado no V Colóquio Internacional Paulo Freire, Recife - 19 a 22 - setembro, 2005, p. 3.

${ }^{89}$ Ibid.

${ }^{90}$ MARX, Karl, A questão judaica, 1978, In: FIGUEIREDO, Maria do Amparo Caetano, Dialogando com Freire e Boaventura sobre emancipação humana, multiculturalismo e educação popular. Texto apresentado no V Colóquio Internacional Paulo Freire, Recife, 19 a 22 - setembro, 2005, p. 3.
} 


\section{Emancipação, Aufklärung, esclarecimento.}

Segundo Adorno, ${ }^{91}$ a exigência de emancipação parece ser evidente numa democracia. Para explicar o que entende por emancipação, o autor retoma Kant no breve ensaio intitulado Resposta à pergunta: o que é esclarecimento. Kant, no texto citado, define a menor idade ou a tutela e também a emancipação, "afirmando que o estado de menor idade é auto-inculpável quando sua causa não é falta de entendimento, mas a falta de decisão e de coragem de se servir do entendimento sem a orientação de outrem. "Esclarecimento é a saída dos homens de sua auto-inculpável menoridade." 92

A relação entre emancipação e democracia está, para Adorno, totalmente vinculada, já que a democracia compreende a participação por intermédio da representatividade nas instituições eleitorais. Para evitar resultados irracionais, é necessário que cada um tenha a capacidade de "se servir de seu próprio entendimento".

Segundo Adorno, a educação, por exemplo, deve formar para a emancipação, e esta proposta deve ser explícita para o conjunto dos educandos.

Para que o termo "emancipação" ou projeto emancipatório não se torne meramente retórico, seria necessário tratar e pensar sobre ele, já que, segundo Adorno, temos a contradição social, e esta continua sendo heterônoma, isto é: "Nenhuma pessoa pode existir na sociedade atual realmente conforme suas próprias determinações, enquanto isto ocorre, a sociedade forma as pessoas mediante inúmeros canais e instâncias mediadoras, de um modo tal que tudo absorvem e aceitam nos termos desta configuração heterônoma que se desvia de si mesma em sua consciência." 93

Adorno avalia que a razão absoluta, bem como a ilusão que o mundo seja o produto do espírito absoluto, em Kant, pode ser criticada. Argumenta que é permitido duvidar do pensamento, "um pensamento insistente e rigoroso não seria possível de determinar o que seria bom e ser feito, uma prática correta." ${ }^{, 94}$ Ou seja, o pensamento não pode tudo.

\footnotetext{
${ }^{91}$ Theodor W. ADORNO, Educação e emancipação, p. 169.

${ }^{92}$ Ibid.

${ }^{93}$ Ibid., p. 181.

${ }^{94}$ Ibid., p. 174.
} 
A proposta de emancipação na educação, segundo Adorno, seria a formação que faria com que o ser humano conseguisse, por si mesmo, fazer escolhas. Neste sentido, seria emancipar-se não do Estado, mas do outro, para que, sozinhas, as pessoas possam avaliar coisas referentes à sociedade e, conseqüentemente, ao Estado.

Em Dialética do esclarecimento, o tradutor Guido Antonio de Almeida ${ }^{95}$ explica que o termo em alemão "Aufklärung" foi traduzido por "esclarecimento", e não por "iluminismo" ou "ilustração", que são expressões mais usuais no português.

A expressão "esclarecimento" traduz com perfeição não apenas o significado histórico-filosófico, mas também o sentido mais amplo que o termo encontra em Adorno e em Horkheimer, bem como o significado corrente de "Aufklärung” na língua ordinária.

Desta maneira, tanto em alemão como em português, o termo designa o processo pelo qual uma pessoa vence as trevas da ignorância e do preconceito em questões de ordem prática (religiosas, políticas, sexuais etc.).

Em Adorno e Horkheimer o termo é usado para designar o processo de "desencantamento do mundo", pelo qual as pessoas se libertam do medo de uma natureza desconhecida, à qual atribuem poderes ocultos para explicar seu desamparo em face dela. Por isso, o esclarecimento de que falam não é, como o iluminismo, ou a ilustração, um movimento filosófico ou uma época histórica determinada, mas o processo pelo qual, ao longo da história, os homens se libertaram das potências míticas da natureza, ou seja, o processo de racionalização que prossegue na filosofia e na ciência. Mas este não é um simples processo de desmitologização: o fato de que ele tem origem no próprio mito e encontra seu termo atual na mitologia do esclarecimento sob a forma da ciência positiva reflete o fato de que o conhecimento pela dominação da natureza tem lugar pela assimilação dos processos de conhecimento e controle aos processos naturais, e explica por que esse processo de dominação da natureza pode resultar paradoxalmente numa mais complexa naturalização do homem totalmente civilizado. ${ }^{96}$

O conceito de "esclarecimento", sem perder o vínculo que o liga ao conceito crítico e emancipador, não se resume às Luzes do século dezoito. Ele resulta de uma profunda crítica que nos leva a refletir sobre a desilusão do otimismo atribuído ao próprio esclarecimento. Ao contrário do que o termo iluminismo possa designar, ligado à instrução pelo estudo e pela leitura, o conceito de esclarecimento, em Adorno e em Horkheimer, é o reconhecimento da importância da razão, sendo que, ao mesmo tempo, ocorre uma crítica contra ela.

A reflexão realizada por Adorno e Horkheimer é uma análise profunda e refinada daquilo pelo qual, historicamente, passamos rápido demais: a sedução pelo ato de conhecer e,

\footnotetext{
${ }^{95}$ Cf., Theodor W. ADORNO; Marx HORKHEIMER, Dialética do esclarecimento: fragmentos filosóficos, 1985.

${ }_{96}^{1 b i d .}$
} 
assim, de dominar a coisa, ou seja, pela capacidade da razão, elemento que nos diferencia dos animais e que nos possibilita criar e transformar a natureza ao nosso favor. A mesma razão que nos afastou de nossa própria natureza é estudada por Adorno e Horkheimer sem que eles se deixassem seduzir por ela ou ainda por sua Ausência. A discussão sobre o esclarecimento em Adorno e em Horkheimer talvez seja a primeira crítica consistente à razão e à sociedade burguesa. Ironicamente, são as críticas mais radicais que se sucederam.

Adorno e Horkheimer são considerados modernos, e é a chamada concepção pósmoderna que crítica a razão. Mas a crítica aos limites desta já estava presente nos ideários da Escola de Frankfurt, condenando justamente o que a burguesia pensava a respeito e seus âmbitos de atuação na cultura de massa.

Todo o estudo de Adorno e de Horkheimer em Dialética e esclarecimento tem início com a questão: por que a humanidade, em vez de entrar em um estado verdadeiramente humano, está se afundando em uma nova espécie de barbárie?

Partem do pressuposto, pettio principii, de que a liberdade na sociedade é inseparável do pensamento esclarecedor. Contudo, reconhecem que o próprio conceito desse pensamento, tanto quanto suas formas históricas concretas (as instituições da sociedade com as quais está entrelaçado) contêm o germe para a regressão que hoje tem lugar por toda a parte: “Abandonada a seus inimigos, a reflexão sobre os elementos destrutivos do progresso, o pensamento, cegamente pragmatizado, perde seu caráter superador e, por isso, também sua relação com a verdade" 97

Em Dialética do esclarecimento, o primeiro estudo é o fundamento teórico dos subseqüentes, e pode ser reduzido em sua parte crítica a duas teses: "o mito já é esclarecimento, e o esclarecimento acaba por reverter à mitologia". O segundo excurso ocupase de Kant, Sade e Nietzsche. Ele mostra como a submissão de tudo aquilo que é natural ao sujeito autocrático culmina exatamente no domínio da natureza e de uma objetividade cega. Os outros textos trataram da "indústria cultural" e dos "elementos do anti-semitismo".

Emancipar-se, para Adorno e para Horkheimer, é ter a capacidade de discernir, de escolher por si mesmo, de pensar. "Nas palavras de Kant, o esclarecimento "é a saída do homem de sua menoridade, da qual é o próprio culpado. A menoridade é a incapacidade de se

\footnotetext{
${ }^{97}$ Theodor W. ADORNO; Marx HORKHEIMER, Dialética do esclarecimento: fragmentos filosóficos, p. 13.
} 
servir de seu entendimento sem direção de outrem"98 pela razão.

Com este ponto de vista, "esclarecimento" é a possibilidade, por intermédio da razão, para que o indivíduo possa sair da menoridade. Não ocorre por meio do iluminismo ou pelas luzes. Isto é, pela escolarização, mas sim pelo bom e apropriado uso da razão.

Em Kant, tanto enquanto em Leibniz e Descartes, a racionalidade consiste em 'levar a cabo a conexão sistemática, tanto ao subir aos gêneros superiores quanto ao descer às espécies inferiores, ${ }^{99}$. $\mathrm{O}$ aspecto 'sistemático' do conhecimento consiste na 'conexão dos conhecimentos a partir de um princípio, ${ }^{100}$. O pensamento, no sentido do esclarecimento, é a derivação do conhecimento factual a partir de princípios, não importa se estes são interpretados como axiomas arbitrariamente escolhidos, idéias inatas ou abstrações supremas. ${ }^{101}$

A base da Educomunicação, segundo Soares ${ }^{102}$, é criar ambientes, ecossistemas comunicativos, que permitam o diálogo franco, aberto e democrático, ou seja, o diálogo como forma de comunicação, e não como mera transmissão. Trata-se de um "campo emergente de intervenção social" que busca garantir a emancipação dos sujeitos e a liberdade de sua expressão, conceitos presentes em textos de Adorno, Horkheimer, Freire, Kaplún e do próprio Soares. Por isso, os termos emancipação, autonomia e liberdade são tão especiais para a nossa análise.

\section{O diálogo: preâmbulo}

Venício A. de Lima, ao fazer um profundo estudo nos textos: Educação como prática da Liberdade; Extensão ou comunicação?; Cultura Freedom in Latin America; Cultura Action: a Dialética Abnalysis; Pedagogia do Oprimido; Ação Cultural para a Libertação; Cartas a Guiné-Bissau e Pedagogia da Autonomia e Pedagogia da Indignação, é quem melhor organizou o pensamento freiriano a respeito do conceito de comunicação e diálogo em Paulo Freire.

\footnotetext{
${ }^{98}$ KANT, Immanuel. Beantwortung der Frage: Was ist Aufklärung? In: Kants Werke. Akademie-Ausgabe.vol. VIII, p.35, In: ADORNO, Theodor W. e HORKHEIMER, Marx. Dialética do esclarecimento: fragmentos filosóficos, Rio de Janeiro, Jorge Zahar Ed., 1985, p. 71.

${ }_{99}$ Kritik der reinen Vernunft, op. cit., vol III (2 $2^{\mathrm{o}}$ ed.), p. $435 \mathrm{~s}$, In: ADORNO, Theodor W.; HORKHEIMER, Marx; Ibid., p. 71.

${ }^{100}$ Ibid., p. 428. Ibid., p. 71.

${ }^{101}$ Op. cit. Theodor W. ADORNO e Marx HORKHEIMER, p. 71.

${ }^{102}$ Ismar de Oliveira SOARES, Revista Contato, Brasília, ano 1, n.2, jan/mar. 1999.
} 
Segundo Lima, Freire repensa a noção de comunicação pelo trabalho que desenvolve como consultor internacional das Nações Unidas com projetos de reforma agrária e extensão rural, no Chile, na década de $1960 .^{103}$

A comunicação para Freire, segundo Lima, não estava relacionada com a chamada “comunicação instrumental” e "transmissiva”. Comunicação para Freire era: "ter em comum”, “compartilhar", "estar conectado pela mesma teia simbólica construtora de sentido", em um contexto desigual e contraditório.

Freire escreve conceitualmente sobre comunicação pela primeira vez em 1968 para o Instituto de Capacitación e Investigación em Reforma Agraria (ICIRA) do Chile. "O texto tinha o duplo objetivo de formular uma crítica às atividades de extensão dos agrônomos e servir de base para discussão num grupo interdisciplinar composto por especialistas ligados ao programa de reforma agrária.", 104

O texto para o ICIRA, que se tornaria um ensaio, teve o título de Extensão ou comunicação?, com original de 1968 e publicação em 1971. Consistia em uma abordagem radical na crítica à tradição chamada de "difusionista" norte-americana. "Contrapondo a comunicação à transmissão, Freire argumenta que comunicação é a 'co-participação de sujeitos no ato de conhecer' e que extensão implica transmissão, transferência, invasão." 105

$\mathrm{Na}$ perspectiva freiriana, a comunicação tem ligações intrínsecas com o ato de conhecer. Segundo Lima, Freire parte do pressuposto de que os homens se diferenciam dos animais de maneira particular, porque são capazes de criar e inovar seu mundo.

\begin{abstract}
A diferença fundamental entre o animal, cuja atividade não vai além da mera produção, e o homem, que cria o domínio da cultura e a história através de sua ação no mundo, é que apenas o último é um ser de práxis. O homem, em sua permanente relação com a realidade, produz não apenas bens materiais, coisas sensíveis e objetos, mas também instituições sociais, ideologias, arte, religiões, ciência e tecnologias. ${ }^{106}$
\end{abstract}

Para Freire, os homens são seres criativos. "Eles podem ser tratados como objetos por sistemas sociais opressivos, isto é, podem ser desumanizados, porém isso não altera a 'vocação ontológica' do homem, que é de ser Sujeito, consciente de si mesmo e que interage

\footnotetext{
${ }^{103}$ Venício A. de LIMA, Mídia e política, p. 54.

${ }^{104}$ Ibid., p. 55.

${ }^{105}$ Ibid., p. 56.

${ }^{106}$ Ensaio sobre "A liberdade cultural na América Latina”, CFLA, p. 167-68, In: LIMA, Venício A. de. op. cit. p. 57.
} 
com o mundo e com os outros homens." 107 A interação, segundo Freire, ocorre pela capacidade humana de se comunicar.

Segundo Lima, Freire estrutura a sua discussão sobre o Sujeito que conhece na obra do filósofo espanhol Eduardo Nicol, que formulou seu argumento no contexto de uma discussão acerca da natureza do conhecimento científico e da verdade, a qual afirma que, além das três relações compreendidas pelos conhecimentos - gnosiológico, lógico e histórico - existiria uma quarta relação, também considerada fundamental e indispensável, sem a qual nenhum ato de conhecimento seria possível, a qual Nicol denominou de relação dialógica.

Nicol intercambia a palavra conocimento (conhecimento) com a palavra pensamiento (pensamento). Em ambos os casos, todavia, está referindo-se claramente ao fato de que o conhecimento constitui um processo dinâmico e as quatro relações se acham dialeticamente inter-relacionadas. $\mathrm{O}$ argumento de Nicol, portanto, reivindica que, assim como não existe ser humano isolado, da mesma forma também não existe pensamento isolado. ${ }^{108}$

Na visão de Freire, só o diálogo comunica. Segundo Lima, Freire, ao enfatizar que a comunicação significa co-particiapação dos Sujeitos no ato de pensar, que o objeto do conhecimento não pode se constituir no termo exclusivo do pensamento, mas, de fato, é seu mediador, e que o conhecimento é construído mediante as relações entre os seres humanos e o mundo, ele estaria definindo a comunicação como a situação social em que as pessoas criam conhecimento juntas, transformando e humanizando o mundo, em vez de transmiti-lo, dá-lo ou impô-lo. "A comunicação é uma interação entre Sujeitos iguais e criativos. Mas esta interação é de natureza tal que necessita estar fundamentada no diálogo". ${ }^{109}$ Nesta perspectiva, comunicação jamais será transmissão.

\section{A palavra e a linguagem em Paulo Freire}

Segundo Lima, Freire considerava crucial que o princípio filosófico do diálogo, no nível do ato de conhecer, se realizasse no plano social. Seria justamente esta característica que

\footnotetext{
${ }^{107}$ Op. cit. p. 59.

${ }^{108}$ Segundo Lima, este também é o pensamento de Clifford Geertz em sua discussão acerca do "Crescimento da cultura e a evolução da mente". Sustenta Geertz, ainda segundo Lima, que "o pensar como ato público e aberto envolvendo a manipulação intencional de materiais objetivos é provavelmente fundamental aos seres humanos; e o pensar como ato encoberto e privado, sem recurso a tais materiais, uma capacidade derivada, ainda que não inútil”. CF. Geertz, 1978, p. 90, In: LIMA, Venício A. de., op. cit. p. 61.

${ }^{109}$ Cf. op. cit. Venício A. de LIMA, p. 62.
} 
qualificaria a dimensão política de Freire. Em Pedagogia do oprimido, a comunicação estaria definida como "um encontro entre homens, mediados pela palavra, a fim de dar nome ao mundo" 110

Ao analisar o diálogo como fenômeno humano, a palavra surge como 'essência do próprio diálogo', porém, sustenta ele, a palavra é algo mais que um instrumento que torna possível o diálogo. Buscando os elementos constitutivos de uma palavra, Freire encontra duas dimensões - a reflexão e a ação -, 'numa interação tão profunda que se uma é sacrificada, ainda que em parte, a outra sofre imediatamente'. As conseqüências são, então, ou o verbalismo - o sacrifício da ação -, ou o ativismo o sacrifício da reflexão. Freire prossegue afirmando que "não há palavra verdadeira que não seja ao mesmo tempo práxis. Assim, dizer a palavra verdadeira é transformar o mundo'. ${ }^{11}$

Para Lima, Freire também utiliza a noção de "dizer a palavra verdadeira, nomear o mundo" para a compreensão do processo sociohistórico em que são gerados o pensamento e a linguagem.

Para ele, 'pensamento e linguagem, na medida em que constituem uma totalidade, estão sempre referidos à realidade do sujeito que pensa. $\mathrm{O}$ autêntico pensamento é gerado na relação dialética entre o sujeito e sua realidade histórica e cultural concreta'. Desse modo, no caso das sociedades 'dependentes' ou 'alienadas culturalmente', o próprio pensamento-linguagem encontra-se alienado porque 'dissociado da ação implicada pelo pensamento autêntico'. Isto gera somente 'palavras falas', e não 'palavras verdadeiras'. Freire prossegue argumentando que o tema fundamental do Terceiro Mundo consiste exatamente na 'conquista de seu direito à voz, o direito de pronunciar sua palavra', acrescentando que o homem que 'tem voz' é 'um homem que é sujeito de suas próprias opções, um homem que projeta livremente o seu próprio destino'. ${ }^{112}$

A ação cultural dialógica para a liberdade e a revolução dialógica, em Freire, são os caminhos propostos para que os homens e as sociedades possam conquistar sua verdadeira voz no mundo desumanizado. Na Educomunicação, criar ambientes que propiciem o diálogo é fator fundamental. Por isso, Soares propõe a criação de ecossistemas comunicativos.

\section{Ecossistema comunicativo}

Etimologicamente, o conceito de ecossistema recebe influência direta de duas outras noções, também extremamente caras à formação discursiva que engendra significações sobre

\footnotetext{
${ }^{110}$ Para Lima, “o compromisso de Freire com a ação política reflete seu catolicismo de esquerda, para o qual 'o grande pecado do cristão [é] o pecado da omissão histórica'. In. LIMA, Venício A. de. op. cit., p. 63.

${ }^{111}$ Venício A. de LIMA, op. cit., p. 64.

${ }^{112} \mathrm{Na}$ citação acima, Lima incluiu a citação: "pode-se argumentar que a idéia de 'palavra falsa' é similar ao conceito habermasiano de 'comunicação distorcida'. In.: LIMA, op. cit., p. 64.
} 
tudo o que se refere ao cuidado com o planeta Terra ${ }^{113}$. A primeira está ligada à noção de unidade da Natureza advinda do holismo (noção similar à idéia de monismo), definida por Jan Christian Smuts (1870-1950), em 1926 ${ }^{114}$. A segunda está ligada às várias noções de sistema, abordadas por Karl Ludwig von Bertalanffy (1901-1972), em 1952 $2^{115}$.

\begin{abstract}
Segundo Bonfiglioli, Tansley apresentou sua nova palavra ao mundo da seguinte maneira: "Mas a concepção mais fundamental é, como me parece, o sistema inteiro (no sentido de física), incluindo não apenas o organismo-complexo, mas também o total de fatores físicos que formam o que nós chamamos de ambiente do bioma - os fatores de habitat no sentido mais amplo. São os sistemas assim formados que, do ponto de vista do ecologista, são as unidades básicas da natureza na Terra. Estes ecossistemas, como podemos chamá-los, são dos mais variados tipos e tamanhos. Formam uma categoria de múltiplos sistemas físicos do universo, que variam do universo como um todo até o menor dos átomos. ${ }^{116}$
\end{abstract}

Ecossistema, como conceito novo, participa, antes, de uma formação discursiva dominada pela escritura científica já estabelecida em torno das comunidades vegetais e das investigações biogeográficas, cujas pesquisas tinham seus resultados discutidos entre pesquisadores norte-americanos e ingleses, durante o final do século XIX e início do século XX.

O termo torna-se corrente no campo da Comunicação a partir do livro As tecnologias da inteligência: o futuro do pensamento na era da informática de Pierre Lévy. O autor explica a sua hipótese sobre o surgimento de uma nova ciência denominada por ele de ecologia cognitiva. "A inteligência ou a cognição são o resultado de redes complexas onde interagem um grande número de autores humanos, biológicos e técnicos."117

Para Lévy, o eu não é inteligente sozinho, mas se torna completo com o grupo humano do qual é membro, com sua língua e toda uma herança de métodos e tecnologias intelectuais dentre as quais o uso da escrita. O pretenso sujeito inteligente nada mais é que um dos microatores de uma ecologia cognitiva que o engloba e o restringe. $\mathrm{O}$ pensamento, que era

\footnotetext{
${ }^{113}$ Cristina Pontes BONFIGLIOLI, Discurso ecológico: a palavra e a fotografia no Protocolo de Kyoto. Tese de Doutorado. Departamento de Jornalismo e Editoração. Escola de Comunicações e Artes (USP). 2008.

${ }^{114}$ Jan Christiaan SMUTS. Holism and Evolution, apud. Frank GOLLEY, 1993.

${ }^{115}$ Karl Ludwig von BERTALANFFY, Problems of Life: An Evaluation of Modern Biological and Scientific Thought, 1952, s/p. In: BONFIGLIOLI, Cristina Pontes, op. cit.

116 "But the more fundamental conception is, as it seems to me, the whole system (in the sense of physics), including not only the organism-complex, but also the whole of physical factors forming what we call the environment of the biome - the habitat factors in the widest sense. It is the systems so formed which, from the point of view of the ecologist, are the basic units of nature on the face of the earth. These ecosystems, as we may call them, are of the most various kinds and sizes. They form one category of the multitudinous physical systems of the universe, which range from the universe as a whole down to the atom." Tradução Livre. Tansley, Arthur George. The use and abuse of vegetational concepts and terms. Ecology 16 (3):284-307 apud. GOLLEY, Frank B. A History of Ecosystem Concept in Ecology: more than the sum of the parts, 1993.

${ }^{117}$ Pierre LÉVY, As tecnologias da inteligência: o futuro do pensamento na era da informática, pp.144-145.
} 
apenas característica atribuída ao ser humano, se dá em uma rede na qual neurônios, módulos cognitivos, humanos, instituições de ensino, línguas, sistemas de escrita, livros e computadores se interconectam, transformam e traduzem as representações.

A ecologia cognitiva seria, então, o estudo das dimensões técnicas e coletivas da cognição. A inteligência, segundo Lévy, é sinônimo de cognição, resultado de redes complexas. Redes em que interagem um grande número de atores humanos, biológicos e técnicos.

Martín-Barbero retoma a discussão sobre ecossistema em pelo menos dois textos conhecidos: um de 1998 e o outro de 2002. Para ele, a relação entre comunicação e educação sempre reduziu e continua reduzindo os meios a uma dimensão instrumental, deixando de fora o que seria estratégico pensar.

É importante pensar sobre a inserção da educação nos complexos processos de comunicação da sociedade atual, ou seja, no ecossistema comunicativo - lugar ou lugares de redes complexas de saberes onde os atores são múltiplos, como escreveu Lévy.

Segundo Martín-Barbero, o ecossistema comunicativo constitui o entorno educacional difuso e descentrado em que estamos imersos. Difuso porque é constituído de uma mistura de linguagens e saberes que circulam por diversos dispositivos midiáticos, mas que são densos e intrinsecamente interconectados, ao contrário do que já se escreveu sobre os meios que seriam vazios de conteúdos e ilusórios na forma. O descentramento dos meios estaria relacionado, por exemplo, a dois centros: escola e livros. Estes há muito tempo organizam o sistema educativo.

O desafio que o ecossistema comunicativo coloca para a educação não se resume apenas à apropriação de um conjunto de dispositivos tecnológicos, mas também à emergência de outras culturas. A discussão abrange outros modos de ver, de ler, de perceber e principalmente de representar. No livro La educación desde la comunicación (2002), MartínBarbero chega a escrever que "a escola deve pensar menos nos efeitos ideológicos e morais dos meios e mais nos ecossistemas comunicativos, que são formados pelo conjunto de linguagens, escritas, representações e narrativas que alteram a percepção." ${ }^{118}$. O que

\footnotetext{
${ }^{118}$ Jesús MARTÍN-BARBERO, La educación desde la comunicación, 2002.
} 
implicaria incorporar as novas tecnologias de comunicação e informação como tecnologias intelectuais, se referindo diretamente a Lévy e à ciência cognitiva.

Segundo Soares, Educomunicação é um conjunto das ações inerentes ao planejamento, implementação e avaliação de processos, programas e produtos destinados a criar e a fortalecer ecossistemas comunicativos. Podemos dizer, então, que ecossistema comunicativo representa, "um sistema dinâmico, aberto e dotado de um mínimo de complexidade e que possui uma forma de "mente". ${ }^{119}$ É possível imaginar também um complexo sistema de lógicas próprias e, principalmente, de técnicas que representam, se não a organização do pensamento, a expressão do olhar e do ouvir.

Na Educomunicação, o ecossistema comunicativo assume o significado de espaço que reúne sistemas vivos, organizados internamente. No cotidiano, esses sistemas costumam não dialogar. É por isso que se torna necessário implementar práticas Educomunicativas.

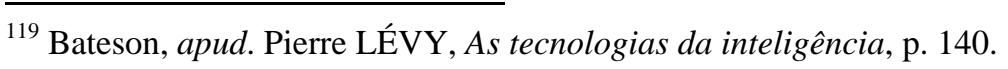




\section{UMA PERSPECTIVA SOBRE A TECNOLOGIA}

Identificamos, no início da tese, que a mediação tecnológica nos espaços educativos se apresenta como uma das áreas do campo da Educomunicação. A proposta de curso a distância - o Educom.TV - fez uso e falou sobre tecnologias na educação. No caso, é oportuno, nesta altura do texto, retomarmos o tema das tecnologias sobre a perspectiva do debate proposto por Adorno e Horkheimer, levando em conta que na Dialética do esclarecimento encontramos a semente que questiona a razão, ou seja, o próprio saber, colocando-o em xeque e revelando o desejo de poder que o esclarecimento almeja.

Ao retomar Adorno, Horkheimer e a discussão sobre o esclarecimento, não temos a intenção de ser inconvenientes, já que o campo da Comunicação está em tempos de mediações e estudos culturais. No entanto, julgamos importante fazê-lo em coerência com os referenciais que estamos adotando neste trabalho.

Podemos recordar, inicialmente, que o programa do esclarecimento significava, para seus autores, o desencantamento do mundo, a libertação do homem que vivia nas as trevas, sob a égide da idéia da fé e das conseqüências do pecado. Entretanto, não podemos esquecer que a razão, o saber, o esclarecimento, enfim, não nos tornaram seres humanos melhores. Fomos capazes de criar Auschwitz, Hiroshima, Nagasaki, Bósnia, Irã, Iraque e, atualmente, produzimos os horrores que ferem a consciência do mundo na faixa de Gaza. Isso sem contar com a indústria da pobreza e da fome, produzida pelo uso inadequado das próprias tecnologias que garantem a riqueza.

A proposta da modernidade era dissolver o mito ou substituir a imaginação pelo saber. Temos a presunção de que dominamos a natureza. "Se nos deixássemos guiar por ela na invenção, nós a comandaríamos na prática." ${ }^{120}$ Criamos um afastamento para, pelos efeitos da distância, conseguirmos abstrair e, com isso, analisar as coisas. Este é o pressuposto nos métodos clássicos da ciência de observação e análise.

O saber ou o conhecimento que se torna poder não conhece barreiras, escrevem Adorno e Horkheimer.

\footnotetext{
${ }^{120}$ Op. cit.,Theodor ADORNO; Marx HORKHEIMER. p. 17.
} 
Os reis não controlam a técnica mais diretamente do que os comerciantes: ela é tão democrática quanto o sistema econômico com o qual se desenvolve. A técnica é a essência desse saber, que não visa conceitos e imagens, nem o prazer do discernimento, mas o método, a utilização do trabalho de outros, o capital. ${ }^{121}$

A técnica é a conseqüência ou o resultado da capacidade humana de abstrair, de calcular, de transformar a natureza. Porém, o preço que pagamos para o desenvolvimento tecnológico foi nosso afastamento dos mitos. Afastamo-nos também do mundo natural e, conseqüentemente, do nosso próprio mundo.

Cindimos a capacidade de conhecer da capacidade de perceber e ainda nos afastamos, por medo, da submissão de toda e qualquer forma de credo que cultivasse a espiritualidade. Substituímos a imaginação. A mesma que nos possibilita criar e visualizar outros mundos, passear por lugares que não existem e, assim, pensar que outras realidades são possíveis.

Adorno e Horkheimer tinham a intenção de criticar o esclarecimento para com isso libertá-lo do que o aprisionava. Segundo estes autores, estávamos de olhos fechados, como a imagem da justiça, só que com um tipo de venda que não nos deixava ver os limites da razão. Adorno e Horkheimer fizeram mais. Eles demonstraram como a sociedade burguesa, com a ascensão do capitalismo, "coisificou” a produção cultural.

O conceito de "Indústria Cultural" mudou o nosso olhar em relação ao processo civilizatório, deixando o burguês consciente envergonhado de si mesmo. Não podemos negar que são válidas as considerações e ponderações feitas por Adorno e Horkheimer a respeito das manifestações artísticas, produtos de uma sociedade capitalista que consegue transformar valores simbólicos em valores de troca, ou seja, mercadoria.

Mesmo amando os produtos da cultura: cinema, televisão e tudo o que a capacidade técnica e criativa do homem conseguiu produzir com a imagem, não podemos deixar de levar em consideração as relações e, principalmente, os interesses econômicos que estão em torno dessas produções. Resgatar Adorno e Horkheimer nos fez perceber quanto o campo da comunicação é injusto e joga fora uma análise refinada que nos auxilia no exercício da reflexão, e por que não dizer da crítica.

No caso específico do objeto em pauta - as tecnologias da informação - a questão não é apenas estar contra ou a favor da técnica na educação. Não podemos cair numa armadilha

${ }^{121}$ Op. cit., Theodor ADORNO; Marx HORKHEIMER, p. 18. 
dualista de caráter eminentemente maniqueísta. Seria, na verdade, uma ingenuidade acreditar que o homem abriu mão de seu desejo de poder e dominação.

Podemos acreditar que a capacidade de transformar a matéria, assim como a utilização dos recursos naturais para garantir a sobrevivência da espécie foram as únicas saídas para que o ser humano não desaparecesse, nos primórdios da humanidade. Entretanto, é possível pensar também que, enquanto éramos nômades, assim como alguns animais, tínhamos a possibilidade de nos servir do que a natureza nos oferecia.

No lugar de dominar o meio ambiente ou lutar contra ele, poderíamos ter aceitado a sua força e a sua produção no tempo e no espaço - primavera, verão, outono, inverno, norte, sul, leste, oeste, frio e calor. O homem se deslocava e tinha em suas mãos tudo o que o espaço podia oferecer. O homem migrava e se movimentava.

Reconhecer a natureza ao invés de querer dominá-la não nos teria impossibilitado a criação e, conseqüentemente, a construção técnica. O que seria diferente reside no princípio potencializador da criação. Uma coisa é criar imbuído do espírito da dominação; outra é realizar atos com o espírito da potencialidade criadora que gera a obtenção do poder para alcançar o belo: o agradável, o aprazível e com isso poder se deleitar, nada impedindo de também usufruir.

A questão do poder criativo, contudo, não está na criação, mas em todo o processo em que o produto é a própria criatura. Victor Frankenstein, personagem da autora Mary Shelley, é um bom exemplo ficcional disso.

O debate não é novo. Contudo, também não está resolvido. Fechar os olhos para a reprodutibilidade técnica, pois esta oferece a produção cultural para uma sociedade que se massificou, talvez não seja a melhor saída, e muito menos a única. Benjamin, mesmo sendo um otimista das possibilidades tecnológicas e demonstrando que elas trazem um novo sensoriun, não está livre de reflexões e análises. Voltemos então ao tema.

Talvez tenha sido um desvio, ou mesmo um equívoco, o caminho que a discussão sobre a técnica tomou na comunicação. Por outro lado, este se justifica com o pressuposto hegemônico do chamado campo comunicacional: a razão e o seu desejo de poder. 
Na medida em que o debate sobre a técnica na comunicação vai para as discussões sobre a cultura, se fecha nos chamados Estudos Culturais, avançamos pouco. Estes dizem que a comunicação não está nos meios, ou seja, não está na perspectiva crítica dos meios (Adorno e Horkheimer) e muito menos com os estudos estruturalistas (Althusser). Ou seja, a questão não é ideológica, e sim cultural.

Daí corremos todas as culturas e seus estudos. Mas, sendo assim, novamente não estaríamos caindo no desejo de poder? Pois, se sairmos da crítica (ou da denúncia) para analisar as mediações, conhecendo as práticas culturais e identificando os processos de significação, estaremos fazendo o quê? Conhecendo o receptor? Mas para quê?

Ou também estaria no bojo dos estudos de recepção o projeto emancipatório e, com outros matizes, o esclarecimento? Tudo isto com outra cor, de outro modo, mas ainda assim resiste o velho desejo de poder. Não é fácil reconhecer, em nós, que o desejo por conhecer carrega outro mais profundo e ardiloso. Palavras que soam estranhas, pois nos revelam.

Do ponto de vista da Educomunicação, a questão se desdobra. Foi com Jorge Huergo, ${ }^{122}$ por intermédio de seus textos escritos e da entrevista que nos concedeu, que percebemos como o campo estava cada vez mais sendo vinculado aos meios técnicos no espaço escolar.

A partir do contato com Huergo e da nossa viagem à Argentina foi que começamos a observar o número crescente, no Brasil, de grupos que querem trocar a denominação da Educomunicação para: "Educomídia" ou "Mídia-Educação", dando ênfase, assim, à formação para o uso, leitura e escrita das mídias. Ou ainda definem Educomunicação como formação para o uso crítico e expressivo dos meios no espaço Escolar. Soares diz que também é, mas não é só isso. Não podemos reduzir a Educomunicação aos meios.

Educomunicação tem recebido o significado de: uso dos meios no espaço escolar, tirando com isso toda a complexidade das práticas e projetos já desenvolvidos que nos mostram que o objetivo não é esse. A Educomunicação deve, cada vez mais, ser reconhecida como campo, e não como uso dos meios.

\footnotetext{
122 Jorge Alberto HUERGO, Hacia uma geneologia de comunicação/educação: Rastreo de algunos anclajes político-culturales. 2005.
} 
Segundo Huergo, que inclusive não trabalha com o termo Educomunicação e sim com “comunicação/educação, ${ }^{123}$ não devemos dissociar o campo da cultura e da política. Com ele, percebemos o quanto nosso olhar minimizou a crítica perante a sociedade capitalista que se desumaniza. Pois, na busca por legitimar as práticas educomunicativas, confundimos processo criativo com processo produtivo.

Huergo analisa que o campo da Comunicação/Educação tem sido reduzido, de maneira crescente, ao instrumental, separando-o dos processos culturais e políticos que servem de contexto e o atravessam. Para o pesquisador, existe um nó que amarra a Comunicação/Educação aos meios e aos recursos técnicos. O mesmo ocorre com as instituições educativas, preferencialmente, a escola. Entretanto, lembra Huergo: "a Comunicação/Educação não está ligada somente à produção dos meios e à escola".

Para estudar o motivo pelo qual a Comunicação/Educação se vinculou aos meios e à instituição escolar, Huergo faz um diagnóstico para investigar como se deu a articulação do campo entre a educação e a cultura. Um bom diagnóstico, escreve Huergo, consiste em situar a Comunicação/Educação entre a cultura e a política e entre os caminhos da história e os dos contextos geopolíticos.

O pesquisador aborda a articulação existente entre o educativo e a cultura nos discursos teóricos, considerando duas etapas na configuração do campo: a genealógica e as referências teóricas que fundam o campo. Huergo analisa a Comunicação/Educação, na Argentina, por meio da genealogia de Domingo Faustino Sarmiento e Saul Alejandro Taborda, além de conceber Paulo Freire como fundador, assim como os autores da comunicação educativa intersubjetiva - Mário Kaplún entre eles.

As questões pesquisadas surgem a partir da prática educativa e, em certo sentido, comunicacional do pesquisador. As questões em forma de problematização aparecem na metade da década de 1970, quando trabalhava com setores populares. As inquietações persistiram, pois estavam relacionadas às práticas educativas e à cultura dos seus interlocutores.

\footnotetext{
123 Jorge Huergo, pesquisador argentino, nomeia a área de "Comunicação/Educação", para garantir a idéia de processo, e não por oposição ao NCE ou a Soares, que nomeiam o campo emergente no Brasil de Educomunicação. A trajetória de Huergo está ligada aos movimentos de teologia da libertação, à militância social e à comunicação popular e menos ao reconhecimento do ofício e de sua formação.
} 
Segundo Huergo, os diferentes contextos políticos: a devastadora ditadura militar, o advento da democracia, a criação e fortalecimento de espaços democráticos e o pesado e injusto neoliberalismo, modelaram as diversas formas da cultura e deixaram profundas marcas e questionamentos que são chaves importantes sobre o sentimento político-cultural daquilo que entendemos por educativo.

Para Huergo, a cultura sempre esteve presente na relação educacional. O autor procura pesquisar as possibilidades e as limitações do planejamento e da gestão de processos comunicacionais educativos. Tenta abordar a problemática geral do diagnóstico, planejamento e gestão de processos de Comunicação/Educação. Entretanto, realiza o trabalho, reconhecendo as limitações das perspectivas instrumentais.

1. Abordar as questões de maneira abstrata é reduzir a discussão a perspectivas instrumentais;

2. O campo Educação/Comunicação tem sido reduzido ao instrumental, sendo, então, separado dos processos políticos e culturais que servem de contexto.

Huergo questiona como foi construído o campo da Comunicação/Educação, assim como a articulação entre a educação e a cultura. Desta forma, realiza a problematização do diagnóstico, planejamento e gestão de maneira integral e complexa, e não meramente instrumental. Para o pesquisador, o referencial teórico é uma produção de significados. "Existem as teorias que assumimos e outras que resignificamos".

Para Huergo, é o projeto neoliberal na educação que acaba enredando a comunicação/educação aos meios (técnica), tanto para a formação dos usos como para sua leitura crítica. Mas o campo é um espaço de formação de subjetividades, de sensibilidades, e não de instrumentalização racional. "Depois dos cálculos estão os homens” escreve Huergo.

A Educomunicação ganhou, no contato com o pesquisador, um sentido - e não um significado - uma energia, uma espécie de algo incorpóreo, não físico, onde a comunicação acontece. A Educomunicação seria o espaço para acolher o diálogo.

Quanto à questão política e cultural - elementos fortes nos trabalhos de Huergo percebemos que há um pouco de místico na perspectiva Comunicação/Educação deste 
pesquisador, talvez por influência dos pressupostos da Teologia da Libertação, da qual ele fez parte.

Foi com Huergo que reconhecemos que as nossas intuições sobre o campo estavam corretas. As práticas educomuicativas são espaços do estar junto, espaços de efetivação do diálogo de maneira criativa. Se isto é utópico, então assim somos. A capacidade criadora e criativa do ser humano é o que nós, educomunicadores, temos que primeiramente reconhecer em nós mesmos e assim cultivar.

A possibilidade de criar e de fazer escolhas nos permite o impulso, o desejo, a produção e a busca do belo, usando um termo mais complexo, para não cair no reducionismo da palavra belo, da estética. O conceito de belo aqui não é apropriado, já que este nos remete aos cânones da Grécia Antiga ou aos grandes mestres da pintura. Não é o caso. Estética serve melhor para a nossa discussão.

A estética é a capacidade criadora potencializada pela sensibilidade, pelas sensações e sentimentos. É também o lugar sensível que possibilita a transformação da matéria, mas não com o espírito utilitário. É este fator que faz o campo da estética não estar no campo da razão e do domínio. Este, pelo menos, não é comum no espírito do artista. A estética associada à ética é: a potência criativa com compromisso.

A técnica consiste em instrumentos: matéria transformada. É o processo criativo que transforma essa matéria, essa é a potência. O que temos que trabalhar nas práticas educomunicativas não é o uso dos instrumentos já criados - este fator pode até fazer parte do programa. O cerne do programa deve consistir em garantir a criação, e esta não acontece quando encerramos a imaginação em prol do discernimento ou do conhecer.

Por isso, até podemos dar acesso aos instrumentos: computador e internet, pois a nossa sociedade desigual não permite a aproximação dessas ferramentas. Por outro lado, a criatividade é a força inventiva do ser humano. E estas são tantas que a cada dia tomamos conhecimento de novas possibilidades criadas por grupos economicamente desfavorecidos em relação ao computador e à internet.

A proposta educomunicativa deve ser a formação da palavra-princípio "Eu-Tu", e não "Eu-Isso". Computador e Internet também podem ser "Tu", quando deixam de ser "Isso". O desafio não está na alfabetização ou no acesso, está na mudança da palavra-princípio e no 
reconhecimento do outro como estrangeiro, diferente, mas sempre "Tu" ao qual o "Eu" está em relação. Um Tu criativo e potente. 


\section{ORA PEQUENA, ORA GRANDE: A RELAÇÃO NO DIÁLOGO}

Assim como ocorre em Alice no País das Maravilhas de Lewis Carroll em que a menina Alice se transforma permanentemente, ora a comunicação é grande e tudo pode, ora é pequena e raramente acontece. Chega um momento em que já não sabemos mais o que ela é, assim como a própria Educomunicação. Esta oscilação pode, inicialmente, causar estranhamento, como a própria Alice relata, "não é agradável mudar de forma, no mesmo dia, várias vezes".

Alice, no livro citado, torna-se muito grande para passar na pequena porta e, quando diminui, percebe que esqueceu a chave lá em cima da mesa, de uma mesa que agora está enorme, pois ela, Alice, está pequena. Vivenciando a Educomunicação, tivemos a mesma sensação, algo nos escapava, mas era porque estávamos em movimento, mudando.

Neste capítulo, vamos dissertar sobre um referencial que não é tão comum para o campo da comunicação. Na mudança entre grande e pequena apreendemos uma outra forma de olhar para as coisas.

\section{A relação "Eu-Tu"}

Vimos o que Freire compreendeu e defendeu por "comunicação" e por "sujeito". Este é o que conhece por intermédio do diálogo. Analisamos o diálogo como mediador no processo do conhecimento. Já a palavra "comunicação" pode ser vista como aquela que "nomeia o mundo" - o que possibilitaria a compreensão desse mesmo mundo. O sujeito que conhece, em Freire, é o sujeito axiológico ${ }^{124}$, o mesmo que não é indiferente e valoriza as coisas, ou seja, atribui valor e, conseqüentemente, significa. É um sujeito que, uma vez consciente da palavra, age no mundo, pode intervir, produz cultura e utiliza a linguagem para isso.

\footnotetext{
${ }^{124}$ Axiologia ou a "teoria dos valores": considerada há alguns anos como parte importante da filosofia ou mesmo como a totalidade da filosofia pela chamada "filosofia dos valores" e por tendências congêneres quando, no início do século XX, a expressão "axiologia" começou a ser empregada em seu lugar. Axiologia: In: ABBAGNANO, Nicola, Dicionário de filosofia, São Paulo, Martins Fontes, 2007, p. 115.
} 
Outro autor que se aprofunda no tema do diálogo é Martin Buber. Mas, para Lima, Buber teria tratado a questão do diálogo de maneira ingênua e por isso teria escolhido Freire para representar as discussões sobre o diálogo na comunicação do ponto de vista político.

Freire, ao contrário, teria voltado toda a sua obra para discutir o diálogo como forma de libertação, como um ato político. Por isso, teria compreendido melhor a dimensão da importância do diálogo, estando este voltado iminentemente para a libertação, por meio do processo de intervenção social. Escreve Lima, ao se referir a Buber: "a sua sensibilidade política parece adormecida ou até mesmo inexistente" ${ }^{\text {125 }}$.

Ao contrário do ponto de vista de Lima, para nós, a maior contribuição de Buber reside justamente na desconsideração da existência de uma relação direta entre o conceito de diálogo e o conceito de política. Isto ficou claro principalmente quando Buber trabalhou em torno da palavra-princípio "Eu-Tu”.

A possibilidade de transformação da relação intersubjetiva reside, para ele, justamente na mudança da relação que o sujeito estabelece com o outro (na relação "Eu-Tu" e não na relação "Eu-Isso"), não sendo necessário, portanto, um discurso sobre o engajamento da intervenção política, ou a sua instrumentalização, e sim, simplesmente, o reconhecimento da importância que o outro adquire. Pois o outro é o "Tu”, e não o "Isso" ou coisa.

O pensamento de Paulo Freire para a Educomunicação ganha relevância por ter sido ele quem ofereceu o fundamento básico para o dado de realidade denominado de Comunicação Popular e por ele ter sido aquele que, primeiramente, chamou a atenção para a importância de se pensar a comunicação como processo de apreensão do mundo pelo diálogo. Mas foi graças a Martin Buber que encontramos as referências para repensar a relação entre o sujeito e o outro, no processo dialógico.

Para que haja, de fato, o diálogo franco, aberto e democrático é necessário que repensemos como nos relacionamos com o outro. Em outras palavras, a relação "Eu-Tu". O diálogo, no processo comunicacional, não pode ser instrumentalizado. Não é a forma diálogo ou a representação do que se entende por diálogo - troca, conversa - que faz com que haja comunicação, mas como o Eu se relaciona com o Tu.

\footnotetext{
${ }^{125}$ Venício A. de LIMA, op. cit., p.71.
} 


\section{Ciro Marcondes Filho e as pesquisas sobre “o Princípio da Razão Durante”.}

Ciro Marcondes Filho, nos últimos vinte anos, vem realizando pesquisas com o objetivo de formatar uma nova teoria para a comunicação. Na caminhada, Marcondes Filho resgatou vários filósofos com o intuito de estudar suas reflexões e análises. Entre os filósofos estudados estão Martin Buber e Emmanuel Levinás. O primeiro escreve sobre a relação "EuTu", e o segundo sobre a alteridade. Os dois juntos nos auxiliam na reflexão sobre o diálogo, o "entre" e a relação.

Marcondes Filho foi quem nos apresentou Buber e sua discussão acerca da relação "Eu-Tu”. Ao pensar sobre a comunicação, filosoficamente, ele nos auxiliou também a refletir sobre a Educomunicação e, principalmente, sobre seus fundamentos.

Foi lendo Martin Buber que percebemos o desvio que nós, novos educomunicadores, tomamos ao ler Freire e Kaplún ${ }^{126}$. Ao utilizarmos o diálogo de forma estratégica para a emancipação e sem conhecer a palavra-princípio - denominada por Buber "Eu-Tu" instrumentalizamos o diálogo. Falha corrigida a tempo.

Antes de adentrar no pensamento buberiano, cabe apresentar alguns pontos do trabalho de Martin Heidegger.

Heidegger foi considerado por seus contemporâneos como o principal expoente da filosofia da existência. Ele atuou como professor por alguns anos na Universidade de Filosofia em Marburgo. Em 1929, sucedeu Edmund Husserl na cátedra de filosofia em Friburgo, dando sua aula inaugural: $O$ que é a metafísica!

O trabalho mais importante de Heidegger é Ser e Tempo. A obra foi considerada por Lévinas como um dos cinco mais belos trabalhos da filosofia. O texto tem como objetivo uma

\footnotetext{
${ }^{126}$ Escritos deixados por Mário Kaplún indicam que ele estava atento ao conceito de comunicação e suas revisões para a comunicação e a educação. Kaplún, antes de falecer, escrevia um livro sobre a Comunicação Educativa, em que estudava Humberto Maturana. Kaplún escreve em Dudas y observaciones sobre Maturana apuntes hechos de memória: ¿Todo lenguajear lleva al conversar? ¿Y todo conversar es concertar, acordar acciones para realizar em común? Em 1998, Kaplún já estudava a comunicação educativa a partir de Maturana. No índice do livro que preparava, ele aponta um subcapítulo para: "relaciones y no medios" e outro para: "problematizar La relación 'totalizante' educacion/comunicación e um capítulo onde trataria: "El ser humano es um ser-em-relación (Heidegger, Jaspers, Buber)". Os escritos foram gentilmente disponibilizados por Gabriel Kaplún, Montevidéu, 2007.
} 
ontologia capaz de determinar adequadamente o sentido do ser. Mas, segundo Giovanni Reale e Dario Antiseri ${ }^{127}$, para alcançar tal objetivo, é preciso analisar quem é que se propõe a perguntar sobre o sentido do ser.

Ser e Tempo, para Reale e Antiseri, é uma análise existencial daquele ente (o homem) que se propõe a perguntar sobre o sentido do ser. Os escritos posteriores a 1930 abandonam a proposição originária: não se trata mais de analisar aquele ente que procura caminhos de acesso ao ser, mas sim o ser mesmo e sua auto-revelação.

Com Heidegger, escreve Marcondes Filho, estamos diante de uma relação dos signos que ultrapassa a mera significação (o jogo e a síntese entre um significado e um significante) e que tampouco cai na metafísica. É uma relação que busca apreender uma existência mutante, transformante, continuamente viva e, por isso mesmo, impossível de ser fixada sob um nome, um conceito, uma noção: “A noção heideggeriana de ser imagina esse ser mais como verbo do que como substância, ser como vida inapreensível mas real”.

Significado e significante, associados em um signo, são capazes de construir uma relação de significação. A significação é como nós decodificamos esse signo, extraindo um entendimento do que se pretende dizer. Por exemplo, quando pronunciamos a palavra "casa", quem ouve entende e visualiza mentalmente um tipo de casa que pode ser grande, pequena, no campo ou na cidade.

O significante é arbitrário, e o significado, ao seu modo, também, escreve Marcondes Filho, pois cada um faz a idéia de casa conforme a sua referência. "Por isso, a significação é uma tradução muito precária do signo. Ela é expressamente lingüística, quer dizer, restringese ao campo de uso da linguagem e ao momento e lugar de seu uso."

Edmund Husserl distingue, em sua fenomenologia, duas dimensões diferentes do signo: noese e noema. Para Husserl, quando nos deparamos com o mundo, temos uma primeira intuição sensorial, uma apreensão imediata da realidade que nos rodeia: as coisas sensibilizam nossos sentidos. O fato que registramos como apreensível, que nos impressiona, é denominado fenômeno: é dele que podemos extrair uma interpretação.

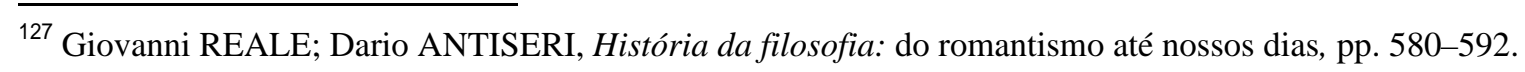


Marcondes Filho nos auxiliou a compreender melhor a questão do apreender pelos sentidos. Quando eu olho uma árvore, explica ele, e esta é uma macieira que está na minha frente, meu cérebro constitui a noese da macieira, eu extraio de múltiplos detalhes uma idéia geral da árvore, eu a reconheço. Isto me faz dizer: "Gente, vejo uma macieira!”. Nesse momento, ele continua, estou preenchendo uma significação, estou cruzando um referente com um significado. Estes me dão a idéia de um significado. Isso tudo, conclui o autor, como sabemos, constitui uma relação de significação.

A expressão, para Husserl - continua Marcondes Filho - será o nível mais abstrato de captação da mesma árvore; será a atribuição de um sentido. "Exprimir", como a própria palavra diz, é pôr para fora (ex-primir). Trata-se de juntar a um objeto externo e à sua representação uma noção de intencionalidade.

Husserl pretende com seu conceito de noema dizer que o sentido é algo que a consciência "doa" à coisa; algo, em verdade, que seria a própria intenção da significação; algo que visa preencher a significação. Para Marcondes Filho, significações meramente lingüísticas são enganosas. Não é possível confiar apenas no enunciado. Segundo o autor, este foi o grande equívoco da lingüística: acreditar que, ao isolar a língua, poderemos compreender a comunicação. O sentido além da significação é algo que vai muito mais longe do que supõe o signo.

Podemos dizer que o real é constituído de duas dimensões: uma mais ou menos fixa, assentada, comportada, fácil de ser apreendida e entendida; e a outra, não tão presa, não tão ligada às coisas, fugidia, difícil de capturar. Esta última, por escapar sempre, contém um “elemento louco em seu interior". Podemos expressar também de outra maneira: há certas relações que estão numa superfície "física", enquanto outras estão numa superfície "metafísica" (metafísica aqui no sentido do sublime, do etéreo, do inefável, daquilo que não pode ser dito pela linguagem).

O que definimos por "sentido", escreve Marcondes Filho, apresenta-se em plano diferente daquele mais elementar que chamamos de "significado". Enquanto na significação as coisas "estão lá", no sentido, continua ele, as coisas se produzem naquele momento: é um evento mágico, ele não é algo que já exista e está sempre lá. Trata-se de uma criação, algo que se constrói no momento em que a coisa acontece. "Não se diz que os acontecimentos tenham sentido, mas eles fazem o sentido." 
Um grande escritor não é aquele cujo livro eu entendo, mas aquele que, através de seu livro, me faz mudar a cabeça e a maneira de ver das coisas. Ele não produz significações, ele produz sentidos. $\mathrm{O}$ sonho, por exemplo, não significa nada exatamente mas ele mexe conosco, nos incomoda, funciona para algo, ele tem sentido. (...) Sentido é o espaço de liberdade do sistema, o campo novo, do inusitado, da quebra de padrões; significações é o campo das repetições, das fórmulas conhecidas, da redução às relações sígnicas. ${ }^{128}$

Reale e Antiseri escrevem que entre as críticas mais freqüentes a Heidegger estão a tortura a que ele submete a linguagem, a arbitrariedade de suas etimologias "relativas" e a sua obscuridade. Entretanto, conta Hans Georg Gadamer:

Com as lições de Heidegger, "os olhos se nos abria, (...) Quando Heidegger ensinava, viam-se as coisas diante de nós, quase como se pudessem ser pegas fisicamente'. Quem poderá esquecer, pergunta Gadamer, 'a frenética voragem de perguntas que ele desenvolvia nas aulas introdutórias do semestre, para depois enredar-se completamente na segunda ou na terceira dessas perguntas, enquanto somente nas últimas aulas do semestre é que se adensavam as escuríssimas nuvens das quais partiam os relâmpagos que nos deixariam meio estupefatos? ${ }^{129}$

Para Marcondes Filho, "sentido", "expressão" e "noema”, todos estes termos repetem a idéia de que fora e além da linguagem ele sente as coisas em sua forma mais plena, ele as vivencia de corpo e alma. Ao contrário do que a racionalidade ocidental se propõe a realizar, o sentir não está na ordem do mensurável, da interpretação, e esta talvez seja a grande diferença entre significado e sentido.

Segundo Lévinas, ${ }^{130}$ que continua pelos caminhos da fenomenologia, assim como para os bergsonianos, a significação não se separa do acesso que ela conduz. O acesso faz parte da própria significação. Porém, a racionalidade nada disso compreende. Tanto em Heidegger como em Lévinas encontramos uma forte crítica à racionalidade ocidental, que exclui o que é da ordem do insondável.

Segundo Lévinas, os andaimes nunca são tirados. E a escada jamais é retirada. Enquanto a alma platônica, liberada das condições concretas de sua existência corporal e histórica, pode alcançar as alturas do Empíreo (Empyrée) para contemplar as idéias, enquanto escravo - conquanto 'entenda o grego' que lhe permita entrar em relação com o mestre chega às mesmas verdades que o mestre.

\footnotetext{
128 Ciro MARCONDES FILHO, Princípio da Razão Durante: por uma teoria do acontecimento em comunicação, 2008.

${ }^{129}$ Hans Georg Gadamer apud. Giovanni REALE; Dario ANTISERI, História da filosofia: do romantismo até nossos dias, p. 592.

${ }^{130}$ Emmanuel LÉVINAS, Humanismo do outro homem, p. 35.
} 
Os contemporâneos, continua Lévinas, pedem ao próprio Deus que passe pelo laboratório, pelos pesos e medidas, pela percepção sensível e até pela série infinita de aspectos na qual o objeto percebido se revela, se Ele quiser ser um físico.

Voltamos ao imensurável, ao que a racionalidade abre mão por não conseguir entender ou encerrar em uma totalidade. Nesta perspectiva, não somos nós que comunicamos, passamos, transferimos ou compartilhamos. A comunicação é acontecimento.

O acontecimento comunicacional é apreendido enquanto sentido: "aquilo que nos toca" é extralingüístico, não cabe nos estudos sobre significação. Assim como a tomada de consciência não é algo que acontece fora do ser, a consciência é o ser. A comunicação não é necessariamente diálogo. Este é o que acontece entre as pessoas, é a atmosfera, a cena. Mas entre as pessoas circula algo, e esse algo é o que chamamos de acontecimento.

Segundo Marcondes Filho, além das palavras emitidas no diálogo, circulam sensações, emoções, desejos, interesses, curiosidades, percepções, estados de espírito, intuição, humores, uma indescritível sensação de "coisa comum”. Quando as pessoas estão desinteressadas, não querem convencer, seduzir e muito menos dominar há, então, a possibilidade do diálogo.

\section{Martin Buber}

Martin Buber trabalhou conjuntamente, na Alemanha, com Franz Rosenzweig e ambos foram responsáveis pela nova versão da Bíblia para o alemão, corrigindo deturpações consideradas gritantes em relação ao trabalho realizado por Lutero. Mas o projeto foi concluído apenas por Buber em 1925, já que Rosenzweig ficou muito doente, vindo a falecer.

A origem do diálogo como objeto filosófico não esteve somente a cargo de Martin Buber, Emmanuel Lévinas e Paulo Freire. Emmanuel Lévinas, por exemplo, foi influenciado por Gabriel Marcel, na França, mas, acima de tudo, por Franz Rosenzweig, que foi o seu professor em Estrasburgo e que, posteriormente, trabalhou com Martin Buber. Anos depois, também temos David Bohm escrevendo Diálogo: comunicação e redes de convivência. 
São inúmeras as relações de proximidade entre Buber e Lévinas no que diz respeito a Rosenzweig. Buber foi também quem de certa forma sintetizou todo um movimento de ateísmo místico do início do século 20, o mesmo que os membros fundadores da Escola de Frankfurt ${ }^{131}$ também fizeram parte e que serviu como fundamentação teórica, no Brasil, no campo da Comunicação, nas décadas de 1960 e 1970.

$\mathrm{Na}$ cartilha de todos esses pensadores de origem judaica (Buber, Rosenzweig, Landauer, Scholem, Benjamin, Horkheimer e Adorno) tentava-se resgatar a noção de redenção e de irrupção catastrófica, ambas voltadas a um ideal de socialismo libertário e utópico. A fantasia revolucionária futurista, para eles, deveria compor com a restauração, realizando ambas, numa espécie de síntese hegeliana, esse tipo de socialismo.

A redenção, explica Marcondes Filho, deixaria de ser, assim, um fenômeno meramente subjetivo, confessional, para se tornar um acontecimento histórico. A "irrupção catastrófica" deveria separar a decomposição do presente das expectativas futuras de uma redenção. Mas a posição de Buber não vai se concentrar na grande revolução, no investimento na mobilização das massas, sequer na politização dos oprimidos.

Ele está preocupado com o homem, com a recuperação do humano numa sociedade cada vez mais técnica. E esta preocupação será traduzida no investimento da relação pessoal com o outro. Para isso, apóia-se primeiramente em estudiosos da linguagem como Hamman, Herder, W. Von Humboldt, de um lado, e no crítico da religião, Ludwig Feuerbach. ${ }^{133}$

Buber, ao se interessar antropologicamente pelo homem, tem por base as idéias de Ludwig Feurbach para extrair o "impulso decisivo" ou o par "Eu-Tu". Mas, em Feurbach, este par estava voltado especialmente às relações homem-mulher, enquanto para Buber a relação "Eu-Tu" vale para qualquer pessoa, inclusive para outros seres vivos. ${ }^{134}$

Para Buber, existem duas atitudes do homem diante do mundo: a primeira - e mais importante - é pré-cognitiva e pré-reflexiva; a segunda é a atitude lingüística social. "A linguagem, diz ele, no melhor estilo heideggeriano, não é conduzida pelo homem: antes, ela o conduz e o instaura no ser." 135

\footnotetext{
${ }^{131}$ Bloch interpreta Deus como o ideal hipostasiado do ser humano, que ainda não se transformou na sua realidade, fazendo do Ateísmo humanista o "herdeiro" legítimo da religião, chegando à tese da natureza atéia do cristianismo e da natureza religiosa do marxismo. Cf. I princípio esperança, 1967; Ateísmo no cristianismo, 1968. In: ABBAGNANO, Nicola, Dicionário de filosofia, São Paulo, Martins Fontes, 2007, p. 99.

132 Ciro MARCONDES FILHO, Princípio da Razão Durante: por uma teoria do acontecimento em comunicação, 2008 (circulação restrita)

${ }^{133}$ Ibid., p. 357.

${ }^{134}$ Ibid., p. 358.

${ }^{135}$ Ibid., p. 359.
} 
Marcondes Filho explica que: para Buber, a palavra é portadora do ser, por meio dela o homem se introduz na existência, visto que ela o conduz e o mantém no ser. Quando o homem fala, quando profere palavras, quando enuncia, o ser se atualiza nele; por intermédio dela, ele "faz-se homem" e firma lugar no mundo com os demais homens. O homem é basicamente um ser dia-logal e dia-pessoal.

O diálogo é o lugar do encontro, algo que, conforme o prefixo dia, atravessa, perpassa a relação. Diálogo, nesta perspectiva, seria uma relação, um discurso, uma razão que perpassa, que está no meio, sendo o "entre", para Buber, a categoria primordial da dialogicidade da palavra. "O entre é o lugar 'onde o espírito habita', o lugar da relação, do encontro, do diálogo. E isso também no amor." 136

Não é fácil entender Buber. Para se ter uma noção, o texto é abstrato, dirige a discussão ao inefável constantemente. Para entrar em suas idéias e pensamentos é necessário não querer capturar e sim perceber o universo buberiano. É necessário abrir mão do conceito de diálogo já estabelecido no campo da Comunicação.

Segundo o seu tradutor Von Zuben, ${ }^{137}$ Buber é mais pensador do que um filósofo acadêmico ou um teólogo profissional. A grande diferença é que Buber sempre manteve vivo o vínculo dos seus pensamentos com a práxis. "Buber radica a gênese e o desenvolvimento de sua reflexão na riqueza e na força vital de sua experiência concreta. Em Buber, reflexão e ação (logos e práxis) foram intimamente relacionadas". ${ }^{138}$

\section{Buber e a palavra-princípio "Eu-Tu"}

Para compreender a noção de diálogo em Buber e principalmente o que ele concebe por relação, é necessário entender a palavra-princípio "Eu-Tu” e "Eu-Isso".

\footnotetext{
136 Ciro MARCONDES FILHO, Princípio da Razão Durante: por uma teoria do acontecimento em comunicação, 2008 (circulação restrita)

${ }^{137}$ Martin BUBER, Eu e Tu, p. 19.

${ }^{138}$ Ibid.
} 
Segundo Buber, o homem pode proferir a palavra-princípio, que não são vocábulos isolados, mas pares de vocábulos em sua dualidade "Eu-Tu" ou "Eu-Isso". Para ele, a vida do ser humano não se restringe apenas ao âmbito dos verbos transitivos.

A vida, em Buber, não se limita apenas às atividades que têm algo por objeto, e isso muito nos interessa, principalmente em tempos de um consumo exacerbado que transforma tudo em "coisa", em que acabamos por nos voltar às pessoas como se fossem também objetos.

Eu percebo alguma coisa. Eu experimento alguma coisa, ou represento alguma coisa. A vida do ser humano não consiste unicamente nisto ou em algo semelhante. Tudo isso e o que se assemelha a isso fundam o domínio do Isso. O reino do Tu tem, porém, outros fundamentos. ${ }^{139}$

Aquele que diz "Tu” não tem coisa alguma por objeto. Pois só onde há uma coisa há também outra coisa, e cada "Isso" acaba sendo limitado por outro isso. O "Isso" só existe na medida em que é limitado por outro "Isso".

Quando proferimos o "Tu”, coisa alguma existe, ou seja, não há mais a coisa, mas o Tu. O “Tu” não se confina a nada. Quem diz "Tu” não possui coisa alguma, não possui nada. Ele permanece em relação. O “Isso", em Buber, é a coisa, e o “Tu” é o "Eu” em relação.

Para Kant, é a experiência que constitui a estrutura de sensibilidade, dando à razão a possibilidade de compreender o mundo. Mas em Buber a capacidade de experiência do homem está onde o homem explora a superfície das coisas e as experimenta. Ele adquire delas um saber sobre a natureza e sua constituição, isto é, uma experiência. Mas ele experimenta o que é próprio às coisas, porém diz Buber: "o homem não se aproxima do mundo somente através de experiências. Estas lhes apresentam apenas um mundo constituído por Isso, Isso e Isso, de Ele, Ele e Ela, de Ela e Isso."140

O experimentador, segundo Buber, não participa do mundo. A experiência se realiza "nele", e não entre ele e o mundo. O mundo não toma parte da experiência. Ele se deixa experienciar, e o mundo, como experiência, diz respeito à palavra-princípio "Eu-Isso". A palavra-princípio "Eu-Tu" fundamenta o mundo da relação. Por isso, é importante perceber como o "Eu" se relaciona com o "Tu", bem como com todas as coisas que se, devidamente pronunciadas, deixam de ser "Isso" e também passam a ser "Tu".

\footnotetext{
${ }^{139}$ Martin BUBER, Eu e tu, pp. 19 e 54.

${ }^{140}$ Ibid.
} 
Segundo Buber, o mundo das relações se realiza em três esferas. São elas: a vida com a natureza, a vida com os homens e a vida com os seres espirituais, principalmente devido ao fato de o homem não ser uma coisa entre coisas ou formado por coisas. Ele não é um simples Ele ou Ela limitado por outros Eles ou Elas, um ponto inscrito na rede do universo de espaço e tempo. "Ele não é uma qualidade, um modo de ser, experienciável, descritível, um feixe flácido de qualidades definidas. Ele é Tu, sem limites, sem costuras, preenchendo todo o horizonte. Isto não significa que nada mais existe a não ser ele, mas que tudo o mais vive em sua luz." 141

O Eu não submete à experiência o "Isso". O homem a quem o Eu diz Tu entra em relação. Mas o Tu não precisa saber que o Eu entra em relação com ele. O Tu é mais do que o Isso possa estar ciente. O Tu encontra-se comigo. Mas é o Eu que entra em relação imediata com ele. Entre o Eu e o Tu não há jogo de conceitos, nenhum esquema, nenhuma fantasia. É importante saber que entre o Eu e o Tu não há fim algum, nenhuma avidez ou antecipação.

A palavra-princípio "Eu-Tu" nos mostra como podemos nos relacionar. Uma relação onde não há a intencionalidade de mudar o Tu, e muito menos de instrumentalizar a relação, mesmo que essa seja para fins políticos. Aliás, o Eu que profere o Tu não deve nada esperar e nada querer, e isto não é ingênuo. Ao contrário, é a relação de um ser maduro que profere o Tu. Aquilo que Lima tomou por ingênuo em Buber é o que há de mais precioso: proferir o “Tu” sem torná-lo "Isso".

Buber escreve que, diante da imediatez da relação, "todos os meios terminam sem significado. Não importando também que meu Tu seja ou possa se tornar, justamente em virtude de meu ato essencial, o Isso de outros "Eus" ('um objeto de experiência geral')". ${ }^{142}$ Ou seja, estar presente no momento de proferir o Tu é fundamental. Buber explica:

\footnotetext{
Com efeito, a verdadeira demarcação, sem dúvida flutuante e vibrante, não se situa entre a experiência e a não-experiência, nem entre o dado e o não-dado, nem o outro mundo do ser e o mundo do valor, mas em todos os domínios entre o Tu e o Isso; entre a presença e o objeto.

O presente, não no sentido de instante pontual que não designa senão o término, constituído em pensamento, no tempo 'expirado' ou a aparência de uma parada nesta evolução, mas o instante atual e plenamente presente, dá-se somente quando existe presença na mente presente, dá-se somente quando existe presença, encontro, relação. Somente na medida em que o Tu se torna presente a presença se instaura. $^{143}$
}

\footnotetext{
${ }^{141}$ Martin BUBER, Eu e tu, p. 57.

142 Ibid., p. 59.

${ }^{143}$ Ibid., pp. 59-60.
} 
Ao contradizer a metodologia clássica acadêmica, Buber afirma que: "o essencial é vivido na presença, as objetividades no passado". Ele não está falando de, ou para um Eu objeto, mas um Eu que é você, que sou eu. Um homem que é atual, que atravessa o mundo das idéias. Pois, segundo Buber, a humanidade se reduziu a um Isso, nada tendo em comum com a humanidade verdadeira e encarnada: aquela em que o homem diz verdadeiramente Tu.

Ao contrário do que possa aparentar, Buber busca escapar da religião, assim como da fixação de um Estado para o povo judaico.

Na tradição do pensamento messiânico-socialista e de um ateísmo místico que apostava numa fantasia internacionalista de libertação, o que importa, de fato, é a forma como o homem se relaciona com seu semelhante, como considera essa alteridade, como sai de si e entrega-se à relação a partir do reconhecimento do outro. ${ }^{144}$

Buber não procura o diálogo para a emancipação ou libertação e nem espera que a relação "Eu-Tu" ocorra após a revolução ou se anteceda a ela. Nas palavras de Buber: "Tomo a quem me ouve pela mão e o encaminho à janela. Abro a janela e aponto para o que está lá fora. Não tenho nenhuma doutrina, mas mantenho uma conversação". ${ }^{145}$ Não há a intenção, muito menos maniqueísmos, estratégias, intencionalidades. Se a isso se dá o nome de ingenuidade é porque não soubemos ler com profundidade o que a palavra-princípio "Eu Tu" quer dizer.

Diálogo geralmente significa duas ou mais pessoas conversando. Eu-Tu, em Buber, não é o Eu que conversa com o Tu em uma troca de palavras. A palavra princípio é como o "Eu" se relaciona com o "Tu". Nesta perspectiva, diálogo é quando duas ou mais pessoas se "atravessam".

$\mathrm{Na}$ perspectiva racionalista surge a pergunta: "como" acontece esse diálogo? Primeiramente é necessário perceber que para Buber é a existência de um Tu que justifica e constitui a existência de um Eu. Dia-logos é igual a lugar do encontro, espaço do "entre".

O diálogo é o lugar ou o espaço onde o encontro acontece, é o "entre”. Entre o Eu e o Tu há um espaço, e é dele que estamos falando. Para Buber, o "entre" é o lugar onde o espírito habita, algo que acontece entre pessoas: o homem habita o amor.

\footnotetext{
144 Ciro MARCONDES FILHO, Princípio da Razão Durante: por uma teoria do acontecimento em comunicação, 2008.

${ }^{145}$ Martin Buber, 1991, p. 693 apud., Ciro MARCONDES FILHO, op. cit., p. 361.
} 
O "entre" é onde habitamos, onde sentimos, lugar onde encontramos o outro. O diálogo é o entre que o Eu pode acolher o outro, trazê-lo para dentro, deixar que o outro entre em mim. O outro me amplia.

É na relação "Eu-Tu" e não "Eu-Isso" que o Eu permite ver o outro, perceber o outro, daí o "outro" me amplia. Trata-se de um local em que as perspectivas deslizam de um ao outro e vice-versa, onde meu interlocutor extrai de mim pensamentos que eu não sabia possuir.

O diálogo é o espaço onde o Eu permite que o outro se mostre, o atravesse, o amplie, “onde deixo com que o outro extraia de mim o que eu nem sabia possuir". Para que isso aconteça é necessário não querer nada do outro: nem formá-lo, nem possuí-lo, muito menos dominá-lo, instruí-lo, ou ainda libertá-lo. O espaço dialógico pode ocorrer quando não quero dominar o outro e deixo o outro atravessar o Eu.

Ao contrário do que pensamos na Educomunicação, vindo das propostas de emancipação, o diálogo não deve ser o espaço para alguma coisa, mesmo que seja para propósitos políticos. O diálogo é o espaço do "Eu-Tu", onde deixo que o Tu me atravesse. Isto é de profunda importância. A riqueza e a profundidade da Educomunicação está no criar ambientes para o diálogo franco, aberto para a participação de todos, sem que exista nisso nenhuma pretensão da captura racionalista.

\section{O Diálogo em Martin Buber}

Buber, ao tentar explicar o diálogo, conta um sonho que se repete. É difícil falar do diálogo na perspectiva buberiana como um conceito. Por isso, optamos por transcrever o relato na íntegra.

\footnotetext{
Com toda espécie de variações, às vezes depois de um intervalo de alguns anos, repete-se para mim o mesmo sonho. Dou-lhe o nome de sonho do duplo apelo. O ambiente em que ele decorre permanece sempre semelhante; é um mundo pobre em aparatos, "primitivos": encontro-me numa grande caverna, como as Latomias de Siracusa, ou numa construção de taipa que me lembra, ao acordar, as aldeias dos felás; ou então na orla de uma floresta tão gigantesca, que não me recordo ter visto jamais uma semelhante. O sonho começa, no início das mais diversas formas, mas sempre, no início, algo extraordinário me acontece: por exemplo, um pequeno animal, com aparência de um filhote de leão cujo o nome conheço no sonho mas não ao acordar, dilacera-me o braço e eu só o domino com
} 
dificuldade. Ora, o estranho é que esta parte do enredo do sonho, a primeira e de longe a de mais interesse, tanto pela sua duração como pela significação exterior dos acontecimentos, desenrola-se sempre num ritmo galopante, como se ela não fosse importante. E então o ritmo torna-se, subitamente, mais lento: eu estou aí e lanço um apelo. A visão global que tenho dos acontecimentos quando estou acordado deveria certamente fazer-me supor que, segundo os fatos que o precederam, o apelo fosse ora alegre, ora assustado, ou ainda ao mesmo tempo doloroso e triunfante. Pela amanhã, todavia, minha memória não me reporta este apelo tão marcado por sentimentos nem tão rico em mutações; é toda vez o mesmo apelo, não articulado, mas de um ritmo rigoroso, ressurgindo de quando em quando, inflando até atingir uma plenitude que minha laringe, em vigília, não suportaria; longo e lento, totalmente lento e muito longo, um apelo que é uma canção - e, quando ele termina, meu coração cessa de bater. Mas, então, em algum lugar ao longe, dirige-se a mim outro apelo; um outro e o mesmo; o mesmo, chamado ou cantado por outra voz, e não obstante não o mesmo; não, não é, de forma alguma, um 'eco' do meu apelo, é muito mais sua verdadeira réplica, não repetindo, som após som, os meus sons, nem de uma forma enfraquecida, mas correspondendo, respondendo a eles - tanto assim, que os meus sons, que ainda pouco não soavam nada interrogativo ao meu próprio ouvido, aparecem agora como interrogações, uma longa série de interrogações, que agora recebem todas uma resposta não interpretável tanto a resposta quanto a pergunta. E entretanto os apelos que respondem àquele um e mesmo apelo parecem não ser igual entre si. A voz é, a cada vez, uma nova voz. Mas, agora que a resposta está terminada, no momento em que o som acaba de se desvanecer, invade-me uma certeza, uma certeza autêntica de sonho: Eis que acontece. Nada mais. Apenas e precisamente isto, exatamente assim: Eis que aconteceu. Se eu tentasse esclarecer os fatos diria: é somente agora, com a réplica, que se deu, de forma real e indubitável, aquele acontecimento que produzira o meu apelo. $^{146}$

Buber diz que o sonho se repetiu até a última vez.

De início, tudo se deu como sempre (era o sonho do animal) meu apelo extinguiu-se e novamente meu coração parou. Mas, então, houve o silêncio. Não veio réplica alguma. Agucei o ouvido, porém não percebi nenhum som. É que, pela primeira vez eu esperava a resposta que sempre me surpreendera, como se eu dela não tivesse jamais tido a experiência; e a resposta esperada não veio. Mas, eis que agora algo aconteceu comigo: como se até então eu não tivesse possuído outras vias de acesso entre o mundo e os meus sentidos a não ser aquelas que passam pelos ouvidos, eu me descobria agora como um ser puro e simplesmente provido de sentidos, sentidos revestidos de órgãos e sentidos nus; oferecime assim ao espaço distante, aberto a toda recepção, a toda percepção. E então veio, não deste espaço distante, mas do ar bem próximo a mim, eis que veio, silenciosamente, a resposta. Para dizer a verdade, ela não veio, ela aí estava. Ela já aí estava - talvez possa dizê-lo à guisa de explicação antes do meu apelo; ela estava simplesmente aí e deixou-se acolher por mim agora que me abri para ela. Eu a percebi de uma forma tão plena, como só percebera a réplica nos meus sonhos anteriores. Se devesse relatar por que meios isto se deu, seria obrigado a dizer: por todos os poros do meu corpo. Como somente o fizera a réplica num dos sonhos anteriores, a resposta correspondia, respondia. Ela ainda a ultrapassava numa perfeição desconhecida, difícil de se definir, justamente pelo fato de já aí estar. Quando eu tinha terminado de acolhê-la, senti novamente, com mais percussão do que nunca, aquela certeza: Eis que aconteceu. ${ }^{147}$

Como explicar o diálogo que acontece, que se cruza nos sentidos e que somente estes conseguem perceber? Tarefa difícil e árdua para ser executada pela palavra escrita, pois esta tudo quer nomear, explicar. Ao mesmo tempo, o suporte da pesquisa e a objetividade exigem a interpretação, já que estamos falando de academia.

Buber nos auxilia neste particular. Ao contar o seu sonho, faz com que nos transportemos a uma narrativa, um local sinestésico em que os sentidos são essenciais.

\footnotetext{
${ }^{146}$ Martin BUBER, Do diálogo e do dialógico, p. 34.

${ }^{147}$ Ibid., p. 35.
} 
Contudo, só aquele que está aberto compreenderá e, simultaneamente, perceberá que a recepção exige o acolhimento. É necessário abrir-se para ouvir ou perceber, tanto a pergunta quanto a resposta, e isto cabe ao sonho narrado por Buber.

O falar realizado de um para o outro, mesmo sendo de maneira ardorosa, não constitui conversação, em Buber. Assim, a conversação não necessita de som e nem sequer de um gesto, pois a linguagem pode renunciar a toda mediação de sentidos e assim é linguagem. "Mas o diálogo humano pode existir sem o signo, apesar de ter neste, isto é, no som e no gesto, a vida que lhe é própria (...) esta existência sem signo, todavia, não tem forma objetiva captável". 148

Buber diz que não pode transmitir ao leitor, sob forma de conceitos, aquilo de que o seu livro sobre o diálogo e dialógico trata e, por isso, tenta representar por meio de exemplos. "O diálogo não se limita ao tráfego dos homens entre si; ele é - é assim que demonstrou ser para nós - um comportamento dos homens um-para-com-o-outro, que é apenas representado no seu tráfego." 149

Mesmo que se possa prescindir da fala, da chamada comunicação, há, contudo, um elemento que parece pertencer, indissoluvelmente, à constituição mínima do diálogo, de acordo com seu próprio sentido: a reciprocidade da ação interior, ou seja, o receptor necessita desejar o diálogo, estar aberto perceptivamente. Trata-se de uma questão fundamental para quem ambiciona trabalhar com Educomunicação.

É válido distinguir três maneiras pelas quais podemos perceber um homem que vive diante dos nossos olhos. (não me refiro a um objeto científico, pois não falo aqui de ciência) $\mathrm{O}$ objeto da nossa percepção não precisa saber nada a nosso respeito e nem saber da nossa presença; é indiferente aqui se ele tem um relacionamento ou um comportamento para com a percepção. ${ }^{150}$

Segundo Buber, há três espécies de diálogo:

$\mathrm{O}$ autêntico, que não importa se é falado ou silencioso, em que cada um dos participantes tem de fato em mente o outro ou os outros na sua presença e no seu modo de ser, e a eles se volta com a intenção de estabelecer uma reciprocidade viva.

\footnotetext{
${ }^{148}$ Martin BUBER, Do diálogo e do dialógico, pp. 36-37.

${ }^{149} \mathrm{Ibid} ., \mathrm{p} .40$.

${ }^{150}$ Ibid., p. 41.
} 
O diálogo técnico, que é movido unicamente pela necessidade de um entendimento objetivo; e o monólogo disfarçado de diálogo, aquele em que dois ou mais homens, reunidos num local, falam cada um consigo mesmo, por caminhos tortuosos, estranhamente entrelaçados e acreditam ter escapado, contudo, ao tormento de ter que contar apenas com os próprios recursos.

A terceira espécie de diálogo consiste naqueles em que os pensamentos não são expressos da forma em que existiam na mente, mas que, no ato de falar, são tão aguçados que podem acertar o ponto mais sensível, e isso sem considerar os indivíduos com quem se fala como pessoas presentes: uma conversação que não é determinada nem pela necessidade de comunicar algo, nem de entrar em contato com alguém, mas é determinada unicamente pelo desejo de ver confirmada a própria autoconfiança, decifrando no outro a impressão deixada, ou de tê-la reforçada quando vacilante. ${ }^{151}$

O diálogo não pode ser provocado mecânica e estrategicamente, muito menos como forma para capturar o outro. O que pode ocorrer é exercermos uma saída de nós mesmos em direção ao outro. Para isso, é necessário partir do nosso próprio interior, é preciso estar em si mesmo e daí realizar o que Buber nomeou de movimento básico que consiste no voltar-separa-o-outro. $^{152}$

Para Buber, a relação dialógica entre duas pessoas é entrega, mas acima de tudo é imersão, é um mergulhar na praia, e não somente contemplá-la, porém, não projetado para o futuro, e sim no instante. É estar presente na sua totalidade.

David Bohm ${ }^{153}$ retoma, mais recentemente, a importância do diálogo. Trata-se do lugar de criação do novo: uma relação de duas ou mais pessoas em que os interlocutores fazem algo comum, dando espaço ao aparecimento desse novo. Não se tratando, de forma alguma, de troca de idéias ou pontos de vista como fragmentos de informação.

Bohm diz que o diálogo pode ocorrer com qualquer número de pessoas, até mesmo com quem está sozinho. "Mesmo uma só pessoa pode ter o sentimento dialógico dentro de si, se o espírito do diálogo estiver presente."

\footnotetext{
${ }^{151}$ Martin BUBER, Do diálogo e do dialógico, p. 54.

152 Ibid., p. 56.

${ }^{153}$ David BOHM, Diálogo: comunicação e redes de convivência, p.34.
} 
Trata-se de algo inédito, que pode não estar presente no ponto de partida. Esse significado compartilhado é a "cola" ou "amálgama" que mantém juntas as pessoas e as sociedades.

Há, assim, um contraste com a palavra "discussão", que tem a mesma raiz de "percussão" e "concussão". Esse termo significa quebrar, fragmentar. Dá ênfase à idéia de análise, na qual podem existir muitos pontos de vista, e cada indivíduo apresenta o seu, que difere do outro. E assim eles analisam, estilhaçam. ${ }^{154}$

O diálogo pode ser uma proposta, um estar presente e abrir-se ao que o outro diz, dobrar-se, alteridade. Para isso, é necessário saber proferir a palavra-princípio "Eu-Tu".

\section{Emmanuel Lévinas}

Emmanuel Lévinas nasceu em Kaunas, na Lituânia, em 1906, filho de um casal judeu. Aos 11 anos, emigrou para a Ucrânia, onde presenciou a Revolução Russa de 1917. Posteriormente, mudou-se da Ucrânia para a França, país onde se fixou. Em 1923, iniciou os seus estudos superiores em Estrasburgo e, em 1927, começa a estudar Fenomenologia com Jean Hering. Trabalhou diretamente com Franz Rosenzweig. ${ }^{155}$

Na curta temporada que vai para Friburgo na Alemanha (1928 e 1929), assiste a um curso ministrado por Edmund Husserl e Heidegger. Considerado o introdutor da Fenomenologia na França, Lévinas defendeu sua tese em 1929 sobre a “Teoria da Intuição na Fenomenologia de Husserl", publicado no ano seguinte, em 1930.

Em 1939, foi preso pelo nacional-socialismo e passou cinco anos nos campos de concentração nazista na Bretanha (Alemanha). A partir de 1930, deseja se naturalizar francês e passa a ser o diretor da Escola Normal Israelita Oriental por 18 anos, depois professor de filosofia em Poitiers em 1964, mais tarde em Paris-Nanterre (1967) e, por fim, na Sorbonne em 1973. Lévinas falece em Paris, em 25 de dezembro de $1995 .{ }^{156}$

\footnotetext{
${ }^{154}$ David BOHM, Diálogo: comunicação e redes de convivência, p.34.

155 A Primeira publicação, no Brasil, sobre Rosenzweig é de Ricardo Timm de SOUZA, Existência em decisão: uma introdução ao pensamento de Franz Rosenzweig, 1999.

${ }^{156}$ SOUZA, José Tadeu Batista de, Emmanuel Lévinas: o homem e a obra, Revista Symposium NOVA FASE, ano

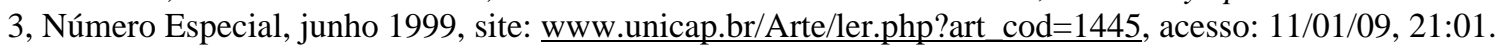


Segundo Magali Mendes de Menezes, ${ }^{157}$ o fato de Lévinas ser um profundo estudioso dos textos talmúdicos ${ }^{158}$ fez com que sua escrita fosse diferente da tradição grega. Outra característica que o torna diferente na sua análise da tradição filosófica é o fato de ter perdido seus familiares durante o nazismo. Fator que lhe forneceu argumentos para acreditar na necessidade de uma revisão do pensamento filosófico e propor uma "ética da ética".

\begin{abstract}
Angustiado pela perda de sentido no humanismo, acreditava que este sentido só poderia ser buscado no compromisso ético. Não uma ética racionalista, que justificasse o dever ser, mas uma ética que nasceria anterior a própria consciência humana. Esta ética encarnada faz do outro questão central de toda sua filosofia". 159
\end{abstract}

Ulpiano Vazques ${ }^{160}$ sugere que as obras posteriores a Humanismo do outro Homem e Outro que ser ou para além da Essência, sobretudo, Deus e a filosofia, consistem em um referencial obrigatório para a interpretação de todo o fazer filosófico de Lévinas, assim como os trabalhos sobre Husserl e Heidegger servirão de chave para a análise das características da relação estabelecida com os filósofos alemães desde os primeiros anos de sua investigação filosófica.

Assim como Buber, Lévinas também não é um autor fácil de compreender, principalmente porque parece que o autor foge do leitor que deseja capturá-lo. Sua forma de escrita, por vezes, acaba dificultando o seu entendimento.

\footnotetext{
${ }^{157}$ MENEZES, Magali Mendes de, A educação no desejo: a linguagem e a ética em Emmanuel Lévinas, s.d. Disponível em:. ihttp://www.anped.org.br/reunioes/31ra/1trabalho/GT17-4892-Int.pdf', acesso em: 28/12/2008 20:15.

158 "O texto talmúdico é bem diferente do texto bíblico. Em primeiro lugar, os autores são conhecidos e constantemente citados. Depois, a construção textual é diferente. Não há uma ordem cronológica; é antes um trabalho sincrônico, que já foi definido como 'uma imensa reunião pública na qual milhares, dezenas de milhares, de vozes, datando de pelo menos cinco séculos, são ouvidas em uníssono' (Ausubel, 1989, p.848); a Bíblia é lacônica, o Talmude exuberante. Cada texto gera mais textos, que são colocados ao redor do primeiro, como se se tratasse do hipertexto criado em computador. Finalmente, e mais importante, enquanto o texto bíblico é prescritivo, o Talmude é dialético, 'cheio de debate, controvérsia e casuísmo que chega aos menores detalhes' (Goldin, 1957, p. 22); um provérbio judaico compara a Torá à água, o Talmude ao vinho. A Bíblia gira em torno à expressão "o quê": o que o ser humano deve fazer, como servo resignado do Senhor. O Talmude explica o "como": como fazer as coisas, sobretudo para sobreviver como pessoas e como comunidade (Browne, 1959, p. 149)." In: Moacyr Jaime SCLIAR. Da Bíblia à psicanálise: saúde, doença e medicina na cultura judaica. tese de doutorado, Fundação Oswaldo Cruz, Escola Nacional de Saúde Pública; 1999. 168p. Disponível em: hittp://portalteses.icict.fiocruz.br/transf.php?script=thes chap\&id=00001804\&lng=pt\&nrm=iso, acesso em: 29/12/2008-14:19.

${ }_{159}$ MENEZES, Magali Mendes de, A_educação no desejo: a linguagem e a ética em Emmanuel Lévinas, s.d. Disponivel em: hhttp://wWw.anped.org.br/reunioes/31 ra/1trabalho/GT17-4892-Int.pdft, acesso em: 28/12/2008 20:15.

${ }^{160}$ Apud. SOUZA, José Tadeu Batista de. Emmanuel Lévinas: o homem e a obra,_Revista Symposium NOVA

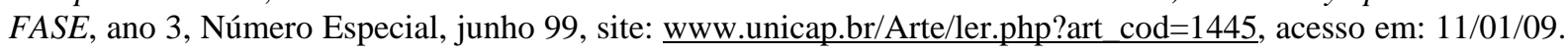
21:02.
} 
Souza, ao fazer uma análise sobre Lévinas e sua obra, resgata o seu tradutor e também pesquisador (Ulpiano) ${ }^{161}$ para dizer que é possível apontar, no conjunto da obra de Lévinas, quatro características internas que, de algum modo, servem de chave de leitura e aproximação:

- A primeira característica que se pode constatar é a oposição entre Filosofia e Teologia;

- Segunda: consiste na oposição entre Metafísica e Ontologia;

- $\quad$ Terceira: pode ser detectada na oposição entre Ética e Fenomenologia;

- Por último, há uma oposição entre Tradição Judaica e Tradição Cristã.

Outras características importantes de destaque são:

- Lévinas foi abertamente partidário da reintrodução da transcendência na Filosofia,

- Foi árduo crítico do estruturalismo, do marxismo, da psicanálise dos anos 60 e 70 ;

- Atuou contra o cientificismo.

Para Lévinas, a filosofia ocidental, assim como a racionalidade ocidental, repulsa ou se nega a olhar aquilo que não consegue ordenar e manipular racionalmente. Entre as muitas entidades que são inteligíveis para eles estão: Deus, o agente individual, o passado histórico, o futuro progressivo, as culturas não-ocidentais e qualquer tradição cultural que seja mitológica ou "supersticiosa" por natureza.

Segundo Lévinas, a filosofia ocidental, por meio da metafísica, mostrou interesse primordialmente pela totalização. Esta é a redução de qualquer forma de diferença à uniformidade. Porém, o estranho, o inexplicável e o imprevisível moldam a condição humana apesar das exigências da racionalidade.

${ }^{161}$ Apud. SOUZA, José Tadeu Batista de. Emmanuel Lévinas: o homem_e a obra, Revista Symposium NOVA FASE, ano 3, Número Especial, junho 99, p. 49. Site: 'WwW.unicap.br/Arte/ler.php?art cod=144Ș, acesso em: 11/01/09. 21:02. 
A condição humana é moldada pela racionalidade, reconhece Lévinas. Portanto, é mais radicalmente dependente dos diversos elementos estranhos que essa mesma racionalidade luta para tornar inteligíveis. Nem tudo conseguimos conhecer e, ao mesmo tempo, o insondável nos constitui.

\section{Lévinas e o “outro".}

A originalidade da proposta de Lévinas está na consideração do outro como um mistério, assim como o conceito de rosto como nudez. ${ }^{162} \mathrm{O}$ outro, para Lévinas, é aquele que tem uma liberdade exterior à minha, que está fora do meu sistema, em que não é possível nenhuma fusão.

O outro é também rosto: presença viva, expressão. Dentro desta lógica, o diálogo assume importância central, afirma Marcondes Filho. "Não o diálogo de homens referente a um terceiro (diálogo Eu-Isso), mas o diálogo buberiano "Eu-Tu", onde o Tu para Lévinas é o feminino. No diálogo, como espaço para a alteridade, eu não possuo o outro, não o submeto; antes submeto-me a ele, sou seu 'diácono'. ${ }^{163} \mathrm{O}$ outro é insondável. Não posso e nem devo capturá-lo. É um infinito que se opõe à totalidade.

No caso da educação, por exemplo, Lévinas diz que não se pode dizer que há dominação. O que ocorre é presença do infinito "que faz saltar o círculo fechado da totalidade". ${ }^{164}$ A ligação com outrem, continua ele, introduz em mim o que não estava em mim. A passagem de um conteúdo, de um espírito a outro, se produz sem violência, se a verdade ensinada pelo mestre já se encontra, desde toda eternidade, no aluno. ${ }^{165}$ Não é a razão que cria as relações entre o Eu e o Outro, sintetiza ele; é o ensino entre Mim e o Outro que cria a razão. ${ }^{166}$

\footnotetext{
162 Ciro MARCONDES FILHO, Princípio da Razão Durante: por uma teoria do acontecimento em comunicação, p. 346.

163 Ibid., p. 347.

${ }^{164}$ Emmanuel LÉVINAS, 1961, p. 153, apud. Ciro MARCONDES FILHO, op. cit., 348.

${ }^{165}$ Ibid., 1961, p. 162, apud. Ciro MARCONDES FILHO, p. 348.

${ }^{166}$ Emmanuel Lévinas, p. 230, apud. Ciro MARCONDES FILHO. op. cit.
} 
Todo o encontro com o outro supõe um deslocamento, "sair do seu lugar e ir ao encontro do outro", dirá Lévinas em Totalidade e Infinito. O Eu, que antes se encontrava na hipocrisia de seu movimento, de um afastamento de si para logo reencontrar-se, no encontro com o outro, perde seu cais, perde o seu país, perde o seu mundo, para descobrir o mundo do outro. O Eu ao encontro do outro encontra o infinito. Contudo, o encontro não faz desaparecer a separação sempre absoluta entre o "Eu" e o "Outro" e tampouco é um vínculo ou uma fusão amorosa.

O outro, assim, como aquele que tem uma liberdade exterior à minha, é o que me deixa sem palavras, (diz Lévinas). Esse outro é incapturável pela psicanálise, ele 'não está no sistema', é um ser transcendente (Lévinas, 1954, p.61). É ao mesmo tempo livre e estranho; mesmo pobre, estrangeiro, miserável é meu igual (...) Desta maneira, o outro garante minha alteridade, minha diferença e não tem nada a ver com fusão, está mesmo no extremo oposto à idéia de amor. ${ }^{167}$

Segundo Marcondes Filho, a entrega que esse outro faz, em Lévinas, está muito além das relações de gênero e espécie, de parte e de todo, de ação e de paixão, de verdade e de erro. Lévinas defende explicitamente uma filosofia do diálogo, que se apóia na tradição filosófica da unidade do Eu (ou do sistema) e da suficiência de si (da imanência). Seus iniciadores foram Buber e Franz Rosenzweig, na Alemanha, e Gabriel Marcel, na França.

Mas o diálogo em Lévinas é diferente daquele de seus predecessores. A importância de Martin Buber,
para Lévinas reside no fato de este eliminar o fundamento gnoseologico do encontro. Eu não encontro
o outro para saber nada, para conhecer coisa alguma, eu realizo, antes, um puro diálogo, uma pura
'aliança', diz Lévinas: volto-me ao outro não porque tenha havido uma proximidade prévia ou por já
estarmos substancialmente unidos mas porque o 'tu' é o absolutamente outro. A relação Eu-Tu é
irredutível, o encontro não se reduz a nada determinável." 168

Magali Mendes de Menezes escreve que, ao acompanhar algumas reflexões presentes no pensamento de Lévinas, percebeu o quanto a sua escrita traz questões importantes para a Educação: "Lévinas nos faz pensar que o mundo humano, a natureza enquanto um ser que pulsa, que se manifesta e tem seu próprio movimento, não pode ser objetivada". ${ }^{169}$

Lévinas também instiga a pensar a Educação a partir da idéia de "dobrar-se ao outro" ou, nas palavras dele, "entregar-se para o outro, ao infinito", sem contudo se perder. Trata-se de receber o outro homem, mulher, criança, negro, rico, pobre, judeu ou católico e ouvi-los, sem, com isso, querer dominar, encerrar ou dogmatizar esse outro. O Outro é alguém que eu jamais conseguirei capturar de tão grande que é.

\footnotetext{
${ }^{167}$ Ciro MARCONDES FILHO, op. cit., p. 350.

168 Ibid., p. 354.

${ }^{169}$ Op. cit. Magali Mendes de MENEZES, p. 9.
} 


\title{
8. Lévinas e o diálogo.
}

No diálogo de Lévinas, o interlocutor é absolutamente estranho. Somente ele (o outro) pode instruí-lo. Neste caminho, Marcondes Filho deduz que a comunicação está próxima da instrução - nada estranho para quem já atua na Educomunicação.

Segundo Lévinas, para pensar, o pensamento recorre às palavras, realiza seu "discurso interior": ele interroga, responde, reflete sobre si mesmo, mas ainda não estamos no campo do diálogo. Circulando entre os homens, há a tentativa de recuperar a unidade do pensamento perdida ao se falar a linguagem que se dobra ao saber (relação Eu-Isso). Um está "no pensamento do outro", quer dizer, suas razões coincidem, estão de acordo, em "uma só alma". Contudo, as coisas não são bem assim, adverte Lévinas. ${ }^{170}$

\begin{abstract}
A neutralidade diante de uma verdade é, também poder de dominação, possibilidade de astúcia. Tanto passo a conhecer outrem, que se torna objeto para mim, não efetivamente 'socialidade', quanto posso ter poder sobre ele, independente do fato de que a supressão da violência pelo diálogo deverá supor que esse outrem aceite ser conduzido ao diálogo. Não, a coisa é bem diferente: 'A filosofia nova do diálogo ensina que invocar ou interpelar o outro homem como tu e lhe falar não depende de uma prévia experiência de outrem, em todo caso, não deriva desta experiência a significação do 'tu'. A socialidade do diálogo não é um conhecimento da socialidade, o diálogo, não é a experiência da conjunção entre homens que se falam. O diálogo seria um acontecimento do espírito, pelo menos tão irredutível e tão antigo quanto o cogito (...) Haveria no diálogo, no Eu-Tu, para além da espiritualidade do saber preenchido pelo mundo e no mundo, a abertura da transcendência ${ }^{171}$
\end{abstract}

O diálogo para Lévinas é algo que transcende a distância sem suprimi-la, sem recuperá-la como o olhar que busca englobar, compreender. O "Eu" e o "Tu" não podem ser objetivamente capturados; não há 'e' possível entre eles, não formam um conjunto, escreve Marcondes Filho. Na prática do diálogo, esconde-se o 'tu da familiaridade', aquilo que Lévinas caracteriza como linguagem sem ensino, silenciosa, entendimento sem palavras, 'expressão no segredo, ${ }^{172}$. Lévinas diz que aquilo que Buber havia descoberto na categoria de relação inter-humana não é, efetivamente, a relação com um interlocutor, mas com a alteridade feminina, em que o feminino se revela como a origem do próprio conceito de alteridade.

\footnotetext{
170 Lévinas, 1980, p. 191, apud. Ciro MARCONDES FILHO, Princípio da Razão Durante: por uma teoria do acontecimento em comunicação, p. 355.

${ }_{171}$ Lévinas, 1980, p. 194, apud. Ciro MARCONDES FILHO. Ibid., p. 356

172 Ibid., 1961, p. 138, apud. Ciro MARCONDES FILHO. Ibid., p. 357
} 
Feminino é esse outrem que me acolhe em casa. Mas ser acolhido pode transformar-se em apossar-se e isso me impedirá de ver as coisas em si mesmas; não devo fruir, não devo me apossar, só preciso saber dar o que possuo. ${ }^{173}$

Cabe lembrar que o feminino em Lévinas não tem relação com gênero ou com a mulher empírica. Trata-se do gesto de acolhimento e de hospitalidade que atinge uma radicalidade essencial e profunda.

\title{
9. O Rosto.
}

Não é fácil entrar nos escritos deixados por Lévinas. Contudo, no livro Ética e Infinito, suas idéias fluem, talvez por ser uma entrevista, ou por já não ser tão desconhecido para nós. É preciso ter a chave, acostumar-se com as palavras, com a escrita.

Sobre o rosto, Lévinas pensa que o acesso a este é, num primeiro momento, ético.

\begin{abstract}
Quando se vê um nariz, os olhos, uma testa, um queixo e se o pode descrever, é que nos voltamos para outrem como para um objeto. A melhor maneira de encontrar outrem é nem sequer atentar na cor dos olhos! Quando se observa a cor dos olhos, não se está em relação social com outrem. A relação com o rosto pode, sem dúvida, ser dominada pela percepção, mas o que é especificamente rosto é o que não se reduz a ele. ${ }^{174}$
\end{abstract}

O rosto em Lévinas é significação, significação sem contexto, o outro na retidão do seu rosto, não é um personagem num contexto. Não é o reitor da Universidade de São Paulo e nem o ator da novela das oito. A relação com o rosto não deve ser a que procura um contexto, deve ser, antes de tudo, ética.

O rosto é o que não se pode matar ou, pelo menos, aquilo cujo sentido consiste em dizer: 'tu não mataras'. O homicídio, é verdade, é um fato banal: pode matar-se outrem; a exigência ética não é uma necessidade ontológica. A proibição de matar não torna impossível o homicídio. ${ }^{175}$

Não é a lei que impossibilita de matar. Lévinas diz que: "desde que o outro me olha, sou por ele responsável, sem mesmo ter de assumir responsabilidade a seu respeito". Habitualmente, somos responsáveis por aquilo que pessoalmente fazemos.

\footnotetext{
${ }^{173}$ Ibid., 1961, p. 152, apud. Ciro MARCONDES FILHO, Ibid.

${ }^{174}$ Emmanuel LÉVINAS, Ética e infinito, p. 69.

${ }^{175}$ Ibid., pp. 70-71.
} 
Entretanto, a responsabilidade não é um simples atributo da subjetividade, como se esta existisse em si mesma, antes da relação ética, declara Lévinas. "A subjetividade não é um para si: ela é, mais uma vez, inicialmente, para o outro." A relação intersubjetiva é uma relação não-simétrica, como já dissemos em parágrafos anteriores. Neste sentido sou responsável por outrem sem esperar a recíproca, ainda que isso viesse me custar a vida.

Sou eu que suporto outrem, dele sou responsável. Vemos, então, que, no sujeito humano, contemporâneo de um sujeito total, se manifesta a minha "primo genitura". A minha responsabilidade não cessa, diz Lévinas.

Trata-se de afirmar a própria identidade do eu humano a partir da responsabilidade, isto é, a partir da posição ou da deposição do eu soberano na consciência de si; deposição que é precisamente a sua responsabilidade por outrem.

Não é uma responsabilidade com culpa, mas algo da subjetividade. "A responsabilidade é que exclusivamente me incumbe e que, humanamente, não posso recuar". ${ }^{176} \mathrm{O}$ que Lévinas entende por ética é essa responsabilidade pelo rosto, por esse outro que é totalidade e infinito.

Para Lévinas, somos responsáveis pelo outro. É a responsabilidade que nos liberta. Idéia que representa o contrário do que foi postulado nas propostas de autonomia. Para o projeto racionalista, o eu se autogoverna, é aquele que se impõe regras pessoais de conduta lógica e compatíveis com os princípios universais da razão.

A razão é aquela que tudo regula, mensura, captura e totaliza em regras universais e que principalmente exclui o outro. Por isso, ele foi tão crítico contra a cientificidade, que por sua vez exclui aquilo que não consegue explicar.

É a responsabilidade pelo outro, a responsabilidade pelo insondável, aquilo que o eu jamais vai conseguir apreender em uma totalidade que liberta o "Eu". Não é a racionalidade que me expande. Esta, ao contrário, encerra o "Eu" na sua totalidade.

É o outro que me atravessa, que me expande, que faz com que eu me abra ao infinito. Neste sentido, propostas que têm como objetivo a autonomia por meio do diálogo que encerra a racionalidade reguladora jamais conseguiram reconhecer o outro.

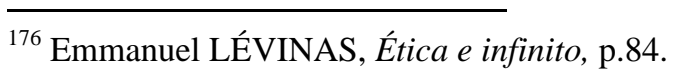




\section{PROJETO EDUCOMUNICATIVO: EDUCOM.TV}

Feche os olhos! Agora imagine que você está em um túnel... você está caindo e não sabe quando vai parar. Durante a queda, você lembra o que deveria ter feito e não fez, recorda-se do que poderia ter sido e não foi. Apesar do convite e da queda, não pense mais no que foi, aproveite a queda. Agora você já está em outro lugar. Não é mais o espírito racionalista que nos guia: estamos tentando perceber.

Começaremos abordando o papel da Gerência de Informática Pedagógica (GIP), setor pedagogicamente ligado à Coordenadoria de Estudos e Normas Pedagógicas (CENP) e, administrativamente vinculado à Fundação para o Desenvolvimento da Educação (FDE), mantendo-se à serviço da Secretaria da Educação do Estado de São Paulo, responsável por promover e coordenar projetos relacionados à informática. Depois, passaremos a falar do projeto em si e da presença do NCE/USP no processo.

\section{O convite da GIP e a proposta do NCE/USP}

A SEE havia recebido da Secretaria de Educação a Distância (Seed) e do Ministério da Educação (MEC) a missão de implementar no Estado um curso sobre linguagem audiovisual denominado TV na Escola e os desafios de hoje. O programa foi concebido para atender a um projeto de capacitação de professores em todo o país, para o uso da TV Escola e de sua programação $^{177}$.

\footnotetext{
177 O Ministro da Educação Paulo Renato implantou o projeto TV Escola, destinado a disponibilizar às redes de educação nos Estados produtos audiovisuais que viesse a facilitar o trabalho pedagógico dos professores no tratamento dos conteúdos curriculares e extra-curriculares. Assim que o canal passou a funcionar, as escolas públicas com mais de cem alunos receberam um kit de educação a distância composto por uma antena parabólica, um vídeo-cassete, um aparelho de TV e dez fitas em VHS, coma recomendação de que cada unidade escolar providenciasse a gravação dos programas para uso em sala de Na ocasião, a SEE tinha aproximadamente, no seu quadro de funcionários efetivos, na qualidade de professores, um total de 250 mil pessoas. aula. A falta de utilização efetiva do recurso levou o Governo Federal a optar pela implantação de um canal, com o objetivo de promover um curso para preparar os professores a fazerem uso do material. O MEC disponibilizou o conteúdo do curso, constituído por uma coleção de textos sobre tecnologia educacional e o emprego do audiovisual na educação, ao que se somava uma coleção de vídeos para reforça da aprendizagem. Caberia às Secretarias de Educação implementar o programa a grupos de seus professores, servindo-se, para tanto, dos préstimos das Universidades Federais localizadas em seus respectivos estados. Por sua vez, caberia às Universidades criar um
} 
Caberia, assim, à SEE implementar o curso em São Paulo, tendo esta responsabilidade sido transferida para a GIP, cuja coordenadora era, na época, a Professora Silvia Galletta,

Com ela, trabalhava uma especialista em comunicação chamada Nancy Barbosa. Reconhecida no meio da comunicação como uma competente profissional envolvida com o tema do vídeo no movimento popular e atenta às questões sociais e políticas, Nancy mantinha também vínculos com o NCE/USP, atuando como articuladora de um dos pólos do projeto Educom.Rádio ${ }^{178}$ que o Núcleo implementava nas escolas da prefeitura municipal da capital paulista.

Diante do desafio da GIP em implementar o curso do MEC, a especialista promoveu uma aproximação entre a coordenadora da GIP, Professora. Silvia, e o coordenador do NCE, Professor Ismar Soares. Era o início, nesse momento, de uma parceria para promover uma experiência diferenciada em prática educomunicativa, da qual tomamos parte, na qualidade de assistente de coordenação.

Foi, pois, a partir do encontro entre os dois coordenadores que surgiu o convite para que o NCE assumisse a aplicação do projeto TV na Escola e os desafios de hoje, para um público de 2.200 professores em atividade em mil escolas da rede, contemplando dois docentes por escola.

Ao analisar o programa da SEED, o Professor Ismar sugeriu à GIP que, mantendo os objetivos gerais do projeto, implementasse uma proposta alternativa em termos de conteúdo e de metodologia. $\mathrm{O}$ embasamento não seria apenas o discurso sobre as tecnologias educativas, mas a Educomunicação como processo criador de ecossistemas comunicativos. $\mathrm{O}$ âmbito não seria expressamente a TV Escola, mas esta no contexto das práticas voltadas para a linguagem audiovisual na perspectiva da educomunicação. Seria dada relevância à formação presencial. Um grupo de supervisores seria formado para acompanhar os cursistas nas Diretorias de Ensino. Dera momento de dar ênfase à formação e avaliação dos tutores para que, finalmente, o grupo de tutores fosse formado por especialistas, mestrandos e doutorandos, acompanhados

ambiente virtual, contratar tutores e administrar o curso em unidades didáticas, denominadas módulos. Previa-se uma duração média de quatro meses de atividades.

${ }^{178}$ Articuladora foi o nome criado no projeto Educom.Rádio para a responsável pelo grupo de mediadores que freqüentavam a Escola, aos sábados. $C f$. Patrícia Horta ALVES, Educomunicação: a experiência do Núcleo de Comunicação e Educação - ECA/USP, dissertação de mestrado, ECA/USP, 2002. Sobre mediadores $c f$., Cláudia Vicenza FUNARI, A prática da mediação em processos educomunicativos: o caso do projeto Educom.Rádio, dissertação de mestrado, ECA/USP, 2007. 
por quatro professores-doutores da ECA/USP. Finalmente, uma infra-estrutura seria montada na própria GIP para acolher um grupo de educomunicadores que daria suporte aos supervisores e aos próprios cursistas, contando com uma linha 0800. As horas de atendimento foram multiplicadas e um orçamento-programa foi aprovado e assumido pela SEE.

A proposta alternativa tinha, portanto, como objetivo geral ${ }^{179}$ : criar condições para formar educadores para o entendimento do conceito e das práticas da Educomunicação, a partir da análise da produção midiática e do uso da linguagem audiovisual em sala de aula. Como objetivo específico, o projeto pretendia formar os professores na expressão audiovisual, ampliando o seu universo expressivo e de interpretação.

A proposta apresentada pelo NCE/USP tomava emprestado dos Parâmetros Curriculares Nacionais para o Ensino Médio (PCNs) as referências para as exigências que fazia aos cursistas, especialmente no que se referia à necessidade de ampliar o conhecimento sobre a comunicação e o uso de suas linguagens no ensino.

Nos exercícios que acompanhavam os módulos, os matriculados eram convidados a rever suas relações com a produção audiovisual, olhando para sua própria condição de consumidores de mídia, e, em seguida, para a realidade representada pelo sistema midiático na sociedade contemporânea e nos processos educativos. A TV Escola passava a ser objeto ela mesma - de análise por parte dos professores, que verificavam o caráter educativo de seus programas e identificavam as maneiras de integrar os produtos veiculados em seus próprios projetos educativos.

Como material de referência, o projeto levou em conta o manual impresso do programa $T V$ na Escola e os desafios de hoje, assim como a produção videográfica disponibilizada pela TV Escola, pela SEE-SP e pelo MEC, por meio de acervos como o da Universidade Virtual Pública do Brasil (UniRede), além dos textos originais produzidos pela equipe de orientadores do NCE/USP.

Recordamos que quando os membros da equipe do NCE/USP tomaram conhecimento da proposta e do número de professores que iriam dela tomar parte, consideram a proposta muito pretensiosa e mesmo utópica, quase impossível de ser executada. A linguagem audiovisual na escola: uma ação educomunicativa, batizado por Soares simplesmente como

${ }^{179} C f$. Relatório do Educom.TV - I, projeto executivo, arquivo da FDE, 2002. 
Educom.TV, mostrou-se, com certeza, um projeto ousado, um Acontecimento, na linguagem de Marcondes filho.

\section{Construindo a parceria.}

Realizar parcerias envolvendo, de um lado, o poder público e, de outro, a Universidade, mesmo se tratando de uma universidade pública, não é tarefa fácil. Cada instituição tem a sua própria cultura, sua lógica, suas dinâmicas, suas coalizões de forças e, ainda, cada uma tem o seu próprio discurso competente. É, pois, nesse jogo de interesses (o administrativo/político de um lado, e o acadêmico, do outro) que um projeto como esse deve ser analisado.

Um terceiro parceiro que conta no processo são os beneficiários. Quando a GIP ofereceu o curso para os professores da rede estadual de São Paulo, por intermédio das Diretorias de Ensino (DEs), as inscrições chegaram a cinco mil. Após várias negociações, o curso começou com 2.240 (dois mil duzentos e quarenta) professores do ensino fundamental e médio, vinculados a 1024 escolas, além de coordenadores pedagógicos indicados pelas DEs regionais e alguns técnicos da própria GIP.

O quarto parceiro (este material, mas estratégico) é a infra-estrutura. Como já adiantamos, o projeto foi desenhado para ser semipresencial. Uma parte da capacitação aconteceria presencialmente, e a outra pela mediação de um Ambiente Virtual de Aprendizagem (AVA). A GIP, que era responsável pela formação continuada na rede de ensino do estado, já fazia planos para criar um AVA, pois afinal a GIP era também a responsável pela capacitação em informática. Nada mais justo do que estar à frente no programa de capacitação. No caso, ao NCE/USP foi oferecido fazer uso dos recursos disponibilizados pela Escola do Futuro, da própria USP, e que já mantinha projetos em desenvolvimento no Estado. A opção do Núcleo, contudo, foi pela criação de um ambiente virtual de aprendizagem próprio - com o concurso de uma empresa, a RealWorks - que permitisse sua reformulação pelos próprios gestores do projeto, sempre que necessário. 


\section{Sobre o discurso competente}

O "discurso competente", do qual falamos no início do subitem anterior, como sendo a pretensão legitimada de cada parceiro, é, segundo Chauí ${ }^{180}$, aquele que pode ser proferido, ouvido e aceito como verdadeiro ou autorizado, porque perde os laços com o lugar e o tempo de sua origem.

Não estamos nos referindo, aqui, apenas à crítica ou à ciência e suas instituições que discutem a quem compete proferir a verdade. Estamos nos referindo ao discurso instituído: "aquele no qual a linguagem sofre uma restrição que poderia ser assim resumida: não é qualquer um que pode dizer a qualquer outro, qualquer coisa, em qualquer lugar e em qualquer circunstância." ${ }^{181}$ Chauí nos auxilia a pensar sobre a nossa experiência com o poder público na seguinte questão:

O discurso competente confunde-se, pois, com a linguagem institucionalmente permitida ou autorizada, isto é, com um discurso no qual os interlocutores já foram previamente reconhecidos como tendo o direito de falar e ouvir, no qual os lugares e as circunstâncias já foram predeterminados para que seja permitido falar e ouvir, enfim, no qual o conteúdo e a forma já foram autorizados segundo os cânones da esfera de sua própria competência. ${ }^{182}$

Onde melhor se determina e se efetua o discurso competente é na burocratização das sociedades contemporâneas e na idéia de organização que se encontra na base desse fenômeno. A burocratização, continua Chauí, é um processo que cada vez mais se impõe ao trabalho e à sua realização. O que foi criado para auxiliar no dia-a-dia do cidadão, ao contrário, dificulta e atrapalha, chegando, simplesmente, a inviabilizar a ação.

Com a expansão do Estado, ocorre o aumento da burocracia, e esta, cada vez mais, justifica-se pela necessidade de organização. Chauí acredita que a ideologia se utiliza do discurso da organização para a presença total ou quase total do Estado na sociedade Civil. Burocratização e Organização pressupõem, segundo ela, as seguintes determinações:

a) a crença na realidade em si e para si da sociedade, de tal modo que a racionalidade dos meios de ação inutiliza automaticamente qualquer questão acerca da racionalidade dos fins da ação; b) existência de um sistema de autoridade fundado na hierarquia, de tal modo que subir um degrau da escala corresponde à conquista de um novo status, uma nova responsabilidade e um novo poder que não dependem daquele que ocupa o posto, mas que pertence ao próprio degrau hierárquico, ou seja, a

\footnotetext{
${ }^{180}$ Marilena CHAUÍ, Cultura e democracia: o discurso competente e outras falas, p. 7.

${ }^{181}$ Ibid., p. 7.

${ }^{182}$ Ibid., p. 9.
} 
reificação da responsabilidade e do poder alcança o grau máximo na medida em que é o cargo, e não o seu ocupante, que possui qualidade determinada; c) como conseqüência, o surgimento de um processo de identificação dos membros de uma burocracia qualquer com a função que exercem e o cargo que ocupam, identificação que se exprime na existência de um cerimonial prefixado que garante o reconhecimento recíproco dos membros na qualidade de superiores e subalternos, bem como o reconhecimento da competência específica de cada um segundo o posto que ocupa; d) a direção que não transcende a burocracia ou a organização, mas também faz parte dela sob a forma de administração, isto é, a dominação tende a permanecer oculta ou dissimulada graças à crença em uma ratio administrativa ou administradora, tal que dirigentes e dirigidos pareçam ser comandados apenas pelos imperativos racionais do movimento interno à Organização. Em uma palavra: temos a aparência de que ninguém exerce poder porque este emana da racionalidade imanente do mundo organizado ou, se preferirmos, da competência dos cargos e funções que, por acaso, estão ocupados por homens determinados. ${ }^{183}$

Não estamos analisando pessoas, e sim as instituições que são conduzidas por indivíduos que, sem saber, integram uma lógica, um modo de ser e de ver as coisas. Vimos a relação entre o poder público e a universidade pública inicialmente como um jogo de xadrez. Tabuleiro onde uma peça tinha que dar o lance antevendo dois lances à frente. Lugar onde cada peça tem uma determinada jogada.

O jogo do discurso competente mostra sua fragilidade e abre espaço para o contraditório quando se sabe que, em ações complexas, nem todos são competentes em tudo.

A nossa meta, por exemplo, ainda no início do projeto, era a de apresentar a Educomunicação. Logo, a nossa prática deveria ser condizente com o que acreditávamos: além de informar sobre nosso discurso (os textos dos módulos), caberia desenvolver uma prática dialógica e organizadora, em que o respeito pelo conhecimento do parceiro (dos tutores e dos cursistas) fosse valorizado e que a aprendizagem se traduzisse numa reflexão mais sobre as relações de comunicação (com o princípio emancipatório), do que sobre as relações de uso dos recursos tecnológicos.

Até então, não conhecíamos a palavra-princípio "Eu-Tu", mas tínhamos como certeza que os professores deveriam se emancipar do cotidiano burocratizado e enfadonho que, segundo a literatura sobre o comportamento docente, havia tomado conta da prática educativa, bem como da escola.

A Educomunicação seria apresentada pela leitura e escrita do audiovisual, mas principalmente por intermédio do AVA. Contudo, na época, a educação a distância encontrava-se em seus primeiros passos, e poucos membros do grupo tinham conhecimentos em profundidade sobre ambientes virtuais de aprendizagem, aliás pouco acreditávamos na

\footnotetext{
${ }^{183}$ Marilena CHAUÍ, Cultura e democracia: o discurso competente e outras falas, p. 10.
} 
possibilidade da educação a distância. O fato obrigou a um reforço no processo de aprendizagem do próprio grupo, por meio da formação de uma equipe multidisciplinar de 50 especialistas.

Cientes destes desafios, a coordenação do NCE/USP se abriu para um diálogo interno e inter-institucional que permitiu uma construção coletiva das etapas do processo. Foi, por exemplo, Marcos Pessoa, funcionário e especialista na área de tecnologia educacional da GIP, quem, com seus conhecimentos em tecnologias da informação, nos convenceu de que a criação de um ambiente virtual de aprendizagem própria seria uma boa experiência para pensar a Educomunicação e a interatividade pelas estruturas de um AVA. A equipe da GIP, ${ }^{184}$ desde o início, aceitou a parceria neste diálogo construtivista nos vários aspectos em que os problemas foram sendo apresentados.

O NCE, com o auxílio de seu coordenador Ismar de Oliveira Soares, desenhou o projeto e sua implementação, em permanente diálogo com Silvia Galletta. Objetivos e procedimentos foram acordados. Soares convidou três professores da ECA/USP para serem co-coordenadores pedagógicos com o objetivo de formar os profissionais até então chamados de "tutores", pelo projeto TV na Escola e os desafios de hoje. Assumiram esta função, os professores doutores Adilson Citelli, Maria Cristina Costa e Marília Franco. O coordenador geral acumulou a função de orientador de um grupo de tutores.

Na coordenação administrativa do NCE estava Patrícia Horta Alves e, para compor a equipe operacional do projeto $^{185}$, foi contratada uma equipe de estudantes, sob a coordenação operacional da narradora desta história.

\section{De Tutores a Mediadores}

Para a contratação dos colaboradores que ficariam responsáveis pelas turmas no ambiente virtual, desenharam um perfil organizado com a colaboração de Hiliana Reis, que

\footnotetext{
184 A equipe coordenada por Silvia Galletta era composta por: Maria Helena Wiechmann, Laura de A. Figueiredo, Regida Eid, Marcos Pessoa, Roberto Sartorello, Gilberto Caron, José Carlos B. Gama, Dalvina Saccomano, Andresa Mourigi com a coordenação da Silvia A. de C. Galletta. Nancy Barbosa deixou a GIP para dar aulas na Faculdade Metodista e também continuar a sua trajetória de pesquisadora.

185 Compunham a equipe: Raphael Alario Rodrigues dos Santos, Denise Cenci, Ana Carolina Altieri Soares e, posteriormente, para auxiliar a organização dos encontros presenciais, foi contratado Carlos César Gomes Lima.
} 
havia obtido seu título doutoral junto à Universidade Autônoma de Barcelona, sobre o tema da tutorial em EaD. Naquele momento, a preocupação maior era com o respeito que o tutor deveria ter com os cursistas:

- O candidato a Tutor deve apresentar capacidade de comunicação oral e escrita - O Tutor deve ser claro e objetivo;

- O candidato a tutor deve apresentar respeito pelos professores da rede Estadual de Educação;

- O candidato a Tutor deve apresentar paciência com os professores da rede Estadual de Educação;

- O candidato a Tutor não deve ser arrogante e muito menos apresentar muita intimidade ou displicência no trato com as pessoas;

- O candidato a Tutor deve ter noções básicas sobre comunicação;

- O candidato a Tutor deve ter experiência com educação - com sala de aula;

- O candidato a tutor, preferencialmente, quando for graduando, deve ser da comunicação;

- Não serão permitidos candidatos de primeiro e segundo grau. Portanto, devem ser especialistas, mestres, mestrandos doutorandos ou doutores;

- O candidato a Tutor que não for da área de comunicação deve apresentar noções básicas de comunicação, bem como experiência em sala de aula.

Todos os candidatos tiveram que passar por uma avaliação escrita e por uma entrevista. Todos foram avaliados pelos conceitos A, B, C e D. Candidatos com conceito C entravam para a lista de espera. Tivemos 89 candidatos.

Do total de candidatos, 56 foram para as entrevistas com os coordenadores pedagógicos. Durante o curso, alguns tutores tiveram que sair do projeto e foram substituídos.

Os tutores que participaram do projeto foram: 
Ademilde Silveira Sartori, Alessandra Cavalheiro Lage, Amaury Ortegosa, Ana Tereza Melo Brandão que, posteriormente, foi substituída por Diogo Noventa, Andréa de Marco Leite de Barros, Bruno Hingst, Carlos Alberto de Castro Gandra Jr., Carmen Lúcia Melges Elias Gattás, Cláudia Deliberai, Daniela Moraes Scoss, Daniel Nobre Kulaif, Elisabeth Márcia Ribeiro Machado, Fábio Pereira Leme, Felipe da Silva Berlim, Fernando Luiz Monteiro de Souza, Flávio de Souza Brito, Jacqueline Pithan dos S. Souza, Jocimar da Silva Lopes, Jurema Brasil, Ivan da S. Massocato que, posteriormente, foi substituído por Robson Braga, Lara Cristina Lourenço Deppe, Luciano Pereira, Marcelo de Carvalho Bonetti, Marcelo R. M. Muller, Maria Salete Prado Soares, Mauro Soares Cordeiro, Mirna Festi, Nalú Maria de Medeiros, Neusa de Fátima Mariano (que logo em seguida foi substituída por Ravel Giordano Paz), Nina Nazario, Ricardo Felix, Rosemary Caldas Yoshimura, Tatiana Rodrigues Nahas e Thiago José Alves Pessoa.

Todos eles tiveram 10 dias para ler e apresentar todo o material impresso enviado pelo projeto TV na escola e os desafios de hoje da Seed/MEC e da Unirede sediados em Brasília, assistir aos vídeos produzidos pela TV Escola disponíveis no acervo da FDE e ler os textos disponibilizados por meio de cópias pelo NCE sobre educomunicação. Todos os tutores foram remunerados com verba alocada junto à FDE da SEE.

Os princípios norteadores de sua ação eram: conhecer a Educomunicação, ter interesse pela literatura existente sobre educação a distância, ter conhecimentos acadêmicos sobre linguagem audiovisual na educação e, principalmente, aceitar o desafio de trabalhar com professores em ação. Foi uma maratona.

Os 35 tutores foram divididos em grupos, ficando, cada um, sob orientação de um dos co-coordenadores pedagógicos. O objetivo era formar, em ação, os tutores responsáveis pelas Salas Virtuais. De maio a dezembro de 2002, às segundas-feiras, tínhamos um encontro presencial de três horas, na ECA/USP, com todo o grupo: os 35 tutores, os cinco membros da equipe operacional, os três co-coordenadores pedagógicos e o coordenador geral. Durante a semana, outras três horas, com os respectivos coordenadores pedagógicos. Durante a semana, os tutores se revezavam em plantões na GIP, no prédio da FDE, no bairro do Bom Retiro. 
Nas primeiras reuniões de coordenadores, a discussão girou em torno do termo "tutor" 186. Todos concordavam que o termo conotava um processo de mando (alguém conduzindo alguém), e o nosso desejo era emancipar, libertar: (construção coletiva de conhecimento pelo poder da partilha e da convivência). Logo, o termo não era condizente com a proposta educomunicativa. Por isso, optamos por denominar o educomunicador que coordenava as reflexões teóricas e as práticas no ambiente virtual de "mediador". O termo "mediador", já usado no projeto Educom.Rádio, tinha como pressuposto "mediar" processos educomunicativos.

\section{Orientação geral da ação dos mediadores}

Segundo Soares ${ }^{187}$, a mídia, em si, não era o objeto das análises do NCE e de seus projetos educomunicativos. Não fazia sentido centrar o trabalho do NCE em projetos de defesa das audiências frente ao possível poder manipulador da mídia; nem estaria o NCE preocupado em compreender a reação dos educadores frente às mensagens massivas (há os que se dedicam a este campo de pesquisa com muita eficiência); nem mesmo tinha interesse em saber se os educadores eram contra ou a favor das tecnologias (tema preferido pelo marketing educacional). O que interessava era, sim, buscar a possibilidade de um diálogo sobre uma ação positiva de intervenção social na construção de ecossistemas comunicativos que garantisse ao maior número de pessoas possível o efetivo espaço da expressão. Para tanto, interessaria a mídia e o conhecimento sobre seu funcionamento.

Tal intervenção acontece, segundo Soares, a partir do cotidiano dos que já estão envolvidos no processo de produção/consumo da cultura. Para tanto, o grupo de pesquisadores do NCE recorreu a Martín-Barbero, que, em entrevista para a Revista Brasileira de Comunicação, apontava para a suposição de que a partir da teoria das mediações seria

\footnotetext{
186 Para nós do projeto, quem acompanhava o professor pelo AVA era chamado de "mediador". Mas, durante o curso, o uso dos termos "mediador" e "tutor" acabaram por surtir confusão, levando o projeto a manter o uso do nome tradicional para efeitos externos ao programa. Nas reuniões de coordenação, a proposta era chamar o tutor de mediador, e o cursista de educando. Considerávamos horrível a indicação do material do MEC que orientava o uso das palavras "tutor" e "cursista". Para não causar uma celeuma, usamos os termos indicados pelo MEC.

${ }^{187}$ MARTÍN-BARBERO, Jesús. Comunicação e Mediações Culturais, Revista Brasileira de Comunicação, São Paulo, vol. XXIII, n.1, pp. 151-163, In: FUNARI, Cláudia Vicenza, op. cit., p.99.
} 
possível encontrar um caminho de aproximação entre os campos da comunicação e da educação.

O que eu comecei a chamar de mediações eram aqueles espaços, aquelas formas de comunicação que estavam entre a pessoa que ouvia o rádio e o que era dito no rádio. Não havia exclusivamente um indivíduo ilhado sobre o qual se incidia o impacto do meio, que era a visão norte-americana.",188

Foi a influência dos estudos de recepção na ECA/USP que acabou orientando o conceito de mediação adotado pela equipe do NCE. O grupo entendeu que mediação significa que "entre o estímulo e a resposta, há um denso espaço de crenças, costumes, sonhos, medos, tudo o que configura a cultura cotidiana." 189

Soares, mesmo reconhecendo que os estudos de recepção representam "um gigantesco subsídio para entender o cotidiano dos sujeitos sociais", entende que os mesmos não são suficientes para produzir mudanças. A mudança vem da ação:

Na verdade, a educomunicação está não apenas frente a receptores "mediados" pelos recursos da informação, mas especialmente frente a cidadãos que podem se converter, eles próprios em "sujeitos mediadores" de processos culturais, através da expressão de seus medos, angústias, alegrias, representações e projetos de intervenção. ${ }^{190}$

Desta forma, e sob este ponto de vista, a denominação "mediador", atribuída aos assistentes das salas virtuais do ambiente virtual de aprendizagem - e que agiam como formadores nos encontros presenciais - garantia a centralidade da noção do partilhamento como a mais essencial das ações da mediação educomunicativa no projeto Educom.TV. Seu objetivo era o de implementar práticas, tanto nas relações constitutivas do curso quanto nos exercícios solicitados aos cursistas, em que o diálogo fosse franco, aberto e democrático. No caso, a pretendida expressão audiovisual só tinha um sentido: garantir a expressão dos professores para que estes propiciassem a mesma experiência aos seus alunos.

\footnotetext{
${ }^{188}$ MARTÍN-BARBERO, Jesús. Comunicação e Mediações Culturais, Revista Brasileira de Comunicação, São Paulo, vol. XXIII, n.1, pp. 151-163, In: FUNARI, Cláudia Vicenza, op. cit., p.99.

${ }^{189}$ Ibid.

${ }^{190}$ Em entrevista para Cláudia Vicenza FUNARI, op. cit., p.99.
} 


\section{Vínculo com os cursistas}

A preocupação com o cursista enquanto sujeito de expressão, levou o projeto a contar com dois dispositivos: a Sala do Educom, no prédio da FDE, e a presença dos Articuladores, nas sedes das Diretorias de Ensino.

A GIP ficava em uma sala no prédio da FDE no Bairro do Bom Retiro, em São Paulo, não muito ampla, pois a equipe era grande para o espaço. Mas, mesmo assim, a Professora Silvia Galletta cedeu uma pequena sala em forma de "L", permitindo que a equipe operacional cumprisse seu papel, oferecendo, também, espaço de trabalho para os mediadores.

A sala contava com 8 computadores com acesso à Internet, uma impressora, um armário e duas linhas de telefone 0800. Com estes aparatos, a equipe se revezava para trabalhar nos computadores e principalmente atender as ligações do 0800 ao longo da semana, das 8 às 19 horas, num fluxo contínuo e ininterrupto.

A equipe operacional era responsável por acompanhar os tutores/mediadores e principalmente os cursistas. Também era responsável por fornecer todo o material pedagógico, responder os e-mails e atender as ligações. Era o ponto de articulação entre todo o grupo: tutores, coordenadores e a própria GIP/FDE.

\section{Os Articuladores}

"Articulador" foi o termo atribuído ao educador que recebeu a missão de dar assistência aos cursistas na Diretoria de Ensino. O objetivo era que este supervisor ficasse responsável por acompanhar todo o processo de formação do docente, permanecendo atento às solicitações dos tutores/mediadores das turmas sob os seus cuidados. Com esta providência, todos os matriculados foram acompanhados, especialmente quando sentiam dificuldades de acesso à plataforma virtual. Os Articuladores municiavam a equipe central do projeto sobre a avaliação que os cursistas faziam de sua própria relação com o curso. Outro objetivo era o de motivar o próprio Articulador a, após o término do projeto, implementar ou 
assessorar seus colegas a desenvolver outros projetos de formação em Educomunicação em sua área.

Para preparar esse profissional para a tarefa que lhe seria confiada, foi realizado um encontro específico, durante uma semana, na cidade de Águas de Lindóia, SP. Evento que contou com a presença dos 180 articuladores (dois por diretoria) nomeados. O objetivo foi o de apresentar o projeto, seus coordenadores, tutores/mediadores e a equipe operacional, bem como oferecer oficinas sobre práticas educomunicativas, linguagem audiovisual, internet e implantação da TV Escola, bem como o uso do seu material.

Durante as oficinas práticas sobre o uso das mídias digitais (Internet), constatamos que boa parte dos próprios articuladores possuía conhecimento limitado sobre como operar o computador e lidar com a Internet. A situação apenas reafirmou a importância de se contar com colaboradores locais que pudessem auxiliar os professores cursistas no desempenho das tarefas requeridas pelo projeto. Em outras palavras, revelou-se como falácia a opinião segundo a qual bastaria disponibilizar uma plataforma virtual de aprendizagem para se ter garantido o sucesso de um curso a distância. 


\section{O AMBIENTE VIRTUAL DE APRENDIZAGEM NO EDUCOM.TV}

$\mathrm{O}$ que fez com que o projeto Educom.TV tivesse tanto sucesso entre os professores que participaram do curso? Os índices de evasão ${ }^{191}$ foram baixos: $86 \%$ dos cursistas concluíram todas as atividades. $\mathrm{O}$ fato chamou a atenção, levando em conta que o que mais havia preocupado o MEC, na avaliação final, fora a alta evasão registrada nas diferentes versões do curso TV na Escola e os desafios de hoje, que deu origem ao Educom.TV.

Não fazia parte da nossa cultura, no início da década ${ }^{192}$, o ato de estar conectado o tempo todo na internet, apesar de ser crescente o número de pessoas que passaram a ter computador em casa com acesso à rede. Neste sentido, a expectativa de êxito de um programa de educação a distância era limitado, pois dependia da mudança de hábito por parte dos cursistas.

Ciente desta condição, a GIP trabalhava com a hipótese de poder contar com ambientes virtuais de aprendizagem que fossem colaborativos, ou seja, em que os recursos técnicos e os cursistas pudessem interagir e realizar estudos e exercícios juntos: um local onde as ferramentas facilitassem o processo de aprendizagem. Por outro lado, ela trabalhou para capacitar os docentes no uso da ferramenta. Para tanto, havia firmado um contrato com a Escola do Futuro, por meio do qual deu início a um projeto destinado a familiarizar o professor com as novas ferramentas. Sua meta era poder contar, também o Educom.TV, com um instrumento capaz de auxiliar o que se entende por "comunicação" 193 entre os cursistas.

Por sua vez, internamente, os pesquisadores do NCE discutiram a hipótese de contar com um projeto de plataforma virtual criado e gerido por estudantes do programa de pósgraduação. A idéia era a de reunir o pessoal da computação, engenharia, comunicação e educação, para, juntos, trabalharem num projeto desta natureza. Nós, do NCE, até tentamos:

\footnotetext{
191 Para não criar confusão com os nomes "professor", "educador", "educomunicador", descreveremos como "cursista" todos os que participaram como alunos do curso Educom.TV.

${ }^{192}$ Artigo de Soares, na revista Comunicação \& Educação, dá conta do crescente número de brasileiros on line, especialmente nos sites de relacionamento. No entanto, esta facilidade não chega a mobilizar os internautas quando o tema é o aprendizado regular e sistemático, como ocorre num curso a distância (ver: Ismar de Oliveira SOARES. "A mediação tecnológica nos espaços educativos: uma perspectiva educomunicativa", In: Revista Comunicação \& Educação, São Paulo, ECA/USP-Edições Paulinas, ano XII, N. 1, jan/abril 2007, p. 31-40).

${ }^{193}$ Colocamos "comunicação" entre aspas, pois entendemos que comunicação não é só troca de informações, compartilhamento de idéias ou possibilidade de conversa, mesmo que a bibliografia da área conote estes significados.
} 
fomos ao Instituto de Matemática e Estatística (IME) e à Escola Politécnica, onde estão reunidos os cursos de engenharia, para verificar o interesse e as possibilidades. Mas, na época, nem os alunos contactados estavam interessados, nem a USP, enquanto instituição, encampou a idéia.

Por intermédio da GIP, chegamos a realizar duas reuniões com a coordenação da Escola do Futuro. Pela proposta da SEE, o NCE produziria o conteúdo, e a Escola do Futuro gerenciaria o portal. A proposta não avançou, levando em conta a decisão do NCE em realizar, ele próprio, uma experiência completa com o campo da $\mathrm{EaD}$, que envolvesse desde o planejamento do curso, a criação do ambiente, a produção dos conteúdos, sua transferência para a linguagem digital até a sua gerência. No caso específico, uma possível colaboração com a Escola do Futuro ficou para uma próxima ocasião.

A definição por criar o próprio ambiente levou o NCE, por seu turno, a contratar uma empresa que aceitou o desafio de produzir conjuntamente com o NCE, um ambiente específico para atender o novo projeto. Foi o que literalmente aconteceu, permitindo superar a dicotomia existente neste meio, com a constituição de grupos específicos (de instructional designers, de conteudistas, de gestores, etc) para exercer as diferentes funções necessárias para possibilitar o funcionamento da plataforma. Felizmente, na equipe do NCE contávamos com mediadores especializados em produção audiovisual e em produção digital que passaram a assessorar a coordenação em seu diálogo com a empresa contratada para operacionalizar a plataforma.

Vivíamos experimentando. Muitas vezes, todos os bancos de dados foram refeitos de um dia para o outro. A Wwbusiness ${ }^{194}$, empresa contratada que se propôs a apreender conjuntamente com o NCE, foi uma grande parceira na construção e desmontagem do instrumento à medida das necessidades. Para tanto, nosso interlocutor com a empresa contratada foi Cássio Roberto Pereira Feitosa Ribeiro, que, posteriormente, continuou acompanhando outros projetos do NCE.

Devido à experiência bem sucedida com Ribeiro, passamos a defender a proposta de criação de um cargo voltado para a interlocução entre a área de conteúdo e a área de produção e gerenciamento da plataforma instrumental. O especialista deveria ter como pressuposto de

\footnotetext{
194 A Wwbusiness trocaria depois sua razão social para RealWorks. Equipe técnica da RealWorks: André Castilho, Angelo Silva, Brunet Dias França Jr., Cássio Roberto Ribeiro, Leonardo Testa.
} 
seu trabalho os referenciais da Educomunicação. Como vimos, a Educomunicação parte do princípio emancipatório. A proposta do NCE era a de implementar um ambiente de educação a distância absolutamente dentro dos pressupostos educomunicativos e foi o que tentamos fazer.

O ambiente foi composto de maneira a oferecer aos cursistas, mediante acesso restrito por senha e login, um conjunto de recursos como: textos, imagens, links, hiperlinks, chat, banco de dados para receber as respostas, tanto dos exercícios propostos, quanto das enquetes dos questionários, tabulando os resultados. ${ }^{195}$

Ribeiro, que foi interlocutor no Educom.TV, posteriormente torna-se aluno do curso de lato sensu da ECA/USP, Gestão de Processos Comunicacionais e propõe a ferramenta "Fórum" como um instrumento para propiciar o debate on-line. Logo em seguida, é lançado o Skype ${ }^{196}$, que disponibiliza o recurso de conversa via áudio, imagem e escrita. Ambientes Virtuais se especializaram e, atualmente, temos ambientes que simulam cidades, com operações bancárias, agências de turismo e tudo o que é possível representar para que o usuário sinta-se "presente" em um ambiente virtual.

$\mathrm{Na}$ verdade, o grande desafio é converter ambientes virtuais de aprendizagem em espaços que não propiciem apenas a instrução, mas principalmente a comunicação. Segundo Adilson Citelli, o que se espera do novo desenho educativo formal é o compromisso com um ensino crítico perante as realidades comunicacionais e tecnológicas, preocupado, sobretudo, em fazer o aluno aprender a aprender. ${ }^{197}$

Entendemos o "aprender a aprender" como a possibilidade de reconhecer que somos seres inconclusos, ou seja, que sempre precisamos permanecer abertos à aprendizagem, tarefa, aliás, que não tem sido fácil de realizar nos últimos tempos, já que reconhecer o "não saber" tornou-se depreciativo, como se fosse uma abertura para a burla. Ao contrário, o costume

\footnotetext{
${ }^{195}$ Assinalamos que a estes recursos foi acrescido um fórum para debates no ambiente que o NCE produziu em outro projeto realizado em parceria com o MEC: o Educomrádio.Centro-Oeste, em 2005.

${ }^{196}$ Skype é uma ferramenta desenvolvida pelo mesmo grupo do KaZaA. Da mesma forma que o KaZaA, o Skype usa a tecnologia Ponto-a-Ponto (P2P - peer-to-peer) para conectá-lo a outros usuários - contudo, não para compartilhar arquivos, mas para conversar com os amigos em qualquer parte do mundo. Mas é possível fazer transferências de arquivos por ele. A tecnologia é avançada, mas simples de usar. $\mathrm{O}$ usuário pode conversar com seus amigos e fazer conferências até com oito pessoas, gratuitamente e com uma qualidade perfeita de som, a qualquer hora. Tudo o que é preciso é ter o Skype instalado em sua máquina e um password (login e senha) cadastrado. Disponível em: 'hhttp://Www.reservaer.com.br/biblioteca/e-books/skype/cap7.htmi. AAcesso em: 3/01/09 - 16:34.

${ }^{197}$ Adilson CITELLI, Comunicação e educação: a linguagem em movimento, p. 141.
} 
passou a ser: "falar sobre tudo", mostrando erudição, mesmo quando esse "tudo" não é mais que literalmente uma aparência.

Um dos grandes desafios na educação é desenvolver atividades que permitam ao educando a abertura para a aprendizagem. Não estamos falando da criança que tudo questiona e quer saber, tem sede por conhecer, mas sim do jovem ou mesmo do adulto que, com o passar do tempo, se considera pronto e acabado. Durante os encontros presenciais do Educom.TV, ouvimos de alguns cursistas que davam aula na rede há quinze anos que não sabiam o que poderiam aprender com jovens tutores.

A imagem que os cursistas criaram dos tutores era de uma pessoa idosa, com óculos de lentes grossas e profundas. Estereótipo que precisou ser dissolvido com o auxílio da relação presencial. Foi interessante perceber primeiramente o susto que os cursistas tiveram no momento em que conheceram os seus tutores e, no final, depois que a relação entre tutor e cursista foi construída. Para que o "eu" possa reconhecer a necessidade de apreender é necessário que esse "eu” tenha a consciência ou o desejo, esteja aberto para isso.

Ambientes Virtuais de Aprendizagens são espaços de interação técnica. Espaços onde podemos trocar informações não possuindo a mesma interação que ocorre entre professor e aluno em espaços virtuais. Mas podemos disponibilizar relatos de discussões.

Durante o curso, percebemos que os participantes tinham não somente dificuldade em usar as ferramentas do computador, bem como as da internet e do ambiente. Também apresentaram dificuldade em se conceberem como profissionais da educação.

O que percebemos durante o Educom.TV é que os cursistas sabem que trabalham na educação, mas a consciência do educador ainda está ausente. Por isso, o que pode parecer problema, como por exemplo: como ocorre o processo de ensino aprendizagem ou o que é aprender não são propriamente "problemas". Apreender, nesta perspectiva, não é uma dificuldade, e sim uma conseqüência natural. Desta forma, não há consciência de que "apreender a apreender" exige um movimento interno de reconhecimento e, conseqüentemente, de mudança.

Quando as angústias apareciam, estas estavam mais relacionadas com questões concretas ligadas à subsistência. Questão fundamental, visto os parcos salários dos 
profissionais da educação no Brasil. Porém, tal situação impede que as discussões não seguissem o tema da política, da estrutura e principalmente do sistema.

O ambiente virtual de aprendizagem do Educom.TV, criado para ser um espaço de acesso ao conhecimento sistematizado e às reflexões sobre a linguagem virtual, tornou-se espaço de troca de experiências e principalmente de relatos de problemas pedagógicos.

Os cursistas ficaram satisfeitos quando perceberam que os tutores conheciam a realidade escolar e estavam dispostos, principalmente, a ouvi-los, ou, no caso do ambiente, a receber o que eles enviavam e prontamente comentavam e respondiam. Porém, num primeiro momento os cursistas estavam dispostos a falar mais.

Os tutores, ao perceberem que os cursistas queriam falar sobre suas atividades e dificuldades profissionais - sobretudo existenciais - abriram o espaço e, assim, a quantidade de mensagens se intensificou. A questão não era responder ao que o exercício pedia, mas estabelecer um contato, iniciar uma conversa com o tutor. Questão que não foi desprezada nem pelos tutores e muito menos pelos coordenadores do projeto.

Tutores despretensiosos e generosos foram mais bem sucedidos. Uma das tutoras foi publicamente homenageada em um dos encontros presenciais. Durante a homenagem, os cursistas relataram que gostaram da tutora porque perceberam o respeito e a disposição dela para ouvi-los. Já os que tiveram como pressuposto a emancipação política, também receberam atenção e carinho. Contudo, as questões estruturais e econômicas sempre tiveram peso nas discussões.

Segundo François Poirié, ${ }^{198}$ falar é arriscar uma aproximação com outrem, é tentar "enredar uma intriga" com ele. Porém, o Dito nunca é o desdobramento ou realização do Dizer, assim como o "sendo" não é o desvelamento do ser. Neste sentido, continua ele, a linguagem não é expressão do pensamento, mas condição de uma tentativa de comunicação. Falar não é simplesmente dizer qualquer coisa. Falar é uma exposição a outrem, conclui Poirié.

A linguagem, para Lévinas, é um dirigir-se ao outro, sem nenhum meio de conhecimento e nenhuma experiência, mas o local de encontro com o outro, com o

\footnotetext{
${ }^{198}$ François POIRIÉ, Emmanuel Lévinas: ensaio e entrevistas, p. 21.
} 
estrangeiro e desconhecido do outro. Contudo, é necessário tomar cuidado com o conceito de encontro em Lévinas, pois encontro não é união, mas aproximação.

\begin{abstract}
Outrem: 'aquele que está sempre além e fora de mim'. Qual movimento pode nos fazer pressentir essa inapreensível proximidade de outrem melhor que a linguagem? No diálogo, outrem, sem revelar-se - a linguagem mascara tanto senão mais, do que revela -, afirma sua presença como outro. Ele me diz que está aí, tendo o poder de falar-me, ouvir-me, responder-me, a partir de seu local irredutível ao meu, distante e no entanto muito próximo. Paradoxo do diálogo: no momento em que creio aproximar outrem, ele me escapa, o Eu (je) daquele que fala e o Eu daquele que é invocado permanecem estranhos um para o outro, o encontro não é união, mas aproximação - em um intervalo - de dois discursos, se misturando, se evadindo: dia-logo. ${ }^{199}$
\end{abstract}

Na minha presença, o outro não é meu igual; ele me é desconhecido, inapreensível pelo olhar, pelas palavras. É este o modo pelo qual o outro é o estrangeiro para Lévinas, ao que ele chama de rosto. "A maneira como se apresenta o Outro, ultrapassando a idéia de Outro em mim, nós a chamamos de rosto". ${ }^{200}$ O rosto significa o infinito.

A relação entre Um e Outro, em Lévinas, entretanto, não se produz pelo desejo de um dos dois em se realizar. A relação com o outro se produz como Desejo, ou seja, como um "ir em direção a", um "abandonar-se a”. Deve ser Desejo ao infinito, Desejo desinteressado, ou, em outras palavras: Bondade. "Esse desejo é uma ruptura do egoísmo ontológico, ao mesmo tempo em que é uma exigência moral.,"201

Segundo Poirié, o que Lévinas denomina como rosto não se reduz à estética, à imagem do rosto. É por isso que a escuta do rosto prima sobre a visão. O encontro com o rosto ocorre no face-a-face, ponto de partida da relação ética.

A relação face a face pode ser concebida rapidamente como uma relação ideal, mas não é isso que Lévinas está dizendo. "Como primeira relação com outrem, o face a face, a via, se é que posso dizer isso, da ética e, quebrando-se no momento da aparição do terceiro (de um outro Outro), conduz à justiça, ou seja, à igualização dos homens e à sua necessária comparação perante a Lei.",202

O que eu posso - o que eu devo - exigir de mim mesmo, o sacrifício para-com-outro até morrer por ele, eu não posso, de maneira nenhuma, exigi-lo de outrem em retorno, porque o que sucede [arrive] a outrem é sempre mais importante do que sucede a mim, pois outrem se esquiva de toda captura, transcendendo 'a ordem estabelecida' de meu saber, eu só posso aceitar uma oferenda, aquela de sua

\footnotetext{
${ }^{199}$ François POIRIÉ, Emmanuel Lévinas: ensaio e entrevistas, p. 24.

${ }^{200}$ Ibid., p. 25.

${ }^{201}$ Ibid., p. 26.

202 Ibid., p. 39.
} 
fraqueza, e agradecer-lhe por poder ser-responsável-para-com ele, sem que ele me peça isso, mas porque eu sou eleito pelo Bem para servir outrem. ${ }^{203}$

Cabe, antes de continuar a nossa análise, voltar ao termo "bondade" em Lévinas. Resgatamos o termo para que o autor não seja mal interpretado ou que se torne sentimental demais, já que vivemos em tempos de egoísmo e individualismo em que toda ou qualquer palavra que apareça com relação ao outro, que tenha conotação afetiva, como carinho ou amor, possa soar também como um termo religioso.

Bondade, em Lévinas, não é um querer-fazer-o-bem. Não é uma caridade calculada que espera o reconhecimento ou até mesmo o cumprimento; não é também uma questão moral. Ao contrário, deve ser praticada na gratuidade e na consciência da sua insuficiência. "Eu jamais sou bom o suficiente uma vez que o outro continua sofrendo". E essa bondade também não é cândida. "É preciso desejar o bem de todo o coração e, ao mesmo tempo, não desejá-lo simplesmente no ingênuo impulso do coração", afirma Lévinas:

\begin{abstract}
A bondade não se traduz por idéia ou óbolos, mas por uma atitude de vida, uma preocupação com o outro vivenciada no cotidiano, permanentemente, na excelência de uma relação social plena, generosa, em que o outro não é considerado como um meio de fazer-se valer (faire-valoir) - prova viva da minha benevolência -, mas como o fim em si de toda a positividade que está em mim, aquela diante da qual eu me apego, aquela que me faz esquecer. ${ }^{204}$
\end{abstract}

A questão não é conceber como inconveniente o sujeito que pára e pergunta se o outro está bem, quando encontra seus colegas de trabalho, e ainda espera para ouvir a resposta. A pergunta não deve ser feita mecanicamente, em que não paramos para ouvir a resposta. A preocupação com o outro deve ser uma preocupação ética subjacente a toda vida em sociedade.

Maria Izabel Leão, ${ }^{205}$ na sua dissertação de mestrado defendida em 2008 com o título O papel da Internet nos projetos educomunicativos do NCE/USP, conclui que ambos os sites Educom.TV e TodeOlho.TV, por ela estudados, apresentavam propostas diferenciadas de educação a distância. Entretanto, os sites comprovam que a interatividade está na ação do tutor, aquele que faz a mediação entre a tecnologia e o cursista, facilitando seu entendimento e proporcionando uma atividade educacional mais dinâmica.

\footnotetext{
${ }^{203}$ François POIRIÉ, Emmanuel Lévinas: ensaio e entrevistas, p. 39.

${ }^{204}$ Ibid., p. 43.

${ }^{205}$ LEÃO, Maria Izabel, O papel da Internet nos projetos educomunicativos do NCE/USP, 2008. Dissertação de mestrado, ECA/USP. São Paulo.
} 
O parâmetro da proposta da educomunicação é que o tutor esteja na gestão da ação, e não na ferramenta em si; que o resultado colha frutos de todo o processo da aprendizagem, e não simplesmente pelo produto constituído da tecnologia. (...)

Como pudemos observar nos dados levantados nesta dissertação, a interatividade para a educomunicação está vinculada muito mais à ação do tutor do que à eficácia do instrumento. Mesmo que a plataforma de EaD seja composta das mais diversas ferramentas de interatividade, o que faz com que ela funcione plenamente é o papel da tutoria. (...)

O site do Educom.TV não tinha sido munido das ferramentas interativas atuais, mesmo assim, através de recursos mais simples, possibilitou um grande vínculo entre tutores e cursistas, garantindo $80 \%$ de finalização com 900 projetos aprovados. Para tanto, foi essencial a atividade presencial de uma semana em sete meses de duração do curso, justamente para colocar face-a-face o tutor e seus cursistas, o que acabou gerando grande afinidade entre os grupos e seus tutores.

Outro fator importante é a qualidade da ação dos tutores, que não se colocavam como "burocratas de tutoria" e, sim, como especialistas em linguagem audiovisual prontos a partilhar seus conteúdos com o grupo de cursistas que mediavam, instigando-os a pensar, a criar alternativas em suas escolas e a entender melhor como se pode processar a tecnologia na sala de aula e até mesmo no ambiente escolar. $^{206}$

O que a maior parte dos Designers Institucionais que trabalham com educação a distância não conseguem apreender é que um ambiente não é bom ou ruim por suas ferramentas. A medida para a relação é deixar que quem conduz a aceitação do exercício ou quem provoca a discussão tenha compromisso e esteja aberto a outra pessoa.

Todas as ferramentas devem ser criadas para auxiliar a relação. Mas, se esta vai acontecer, jamais poderemos dizer, e muito menos exigir. Nesta perspectiva, o projeto Educom.TV, por intermédio do ambiente virtual, foi um sucesso, pois houve a possibilidade do cursista ter acesso às ferramentas e principalmente porque, do outro lado, ele (cursista) sabia que existia uma outra pessoa, que não era igual a ele, um desconhecido, mas que ele resolveu contar as suas angústias e, posteriormente, passa também a ouvir.

O mais difícil durante o curso não foi apreender a usar as ferramentas. Estas dependem simplesmente de acesso e de treinamento. A dificuldade está na relação com a outra pessoa. Particularmente, acreditamos que o sucesso do ambiente virtual consiste na relação presencial que se estabeleceu nos encontros entre tutores e cursistas no face a face. O ambiente auxiliou para que algumas conversas continuassem. Foi assim que se deu a interatividade.

Por isso, defendemos que cursos a distância, técnicos, operacionais e pragmáticos são frios: são a vitória da racionalidade. A interação entre tutor e cursista está na relação "Eu-Tu". Relação não é o bom comportamento de cumprimentos sociais, o politicamente correto.

\footnotetext{
${ }^{206}$ LEÃO, Maria Izabel, O papel da Internet nos projetos educomunicativos do NCE/USP, 2008. Dissertação de mestrado, ECA/USP. São Paulo.
} 
O sucesso do Educom.TV e a permenência de $86 \%$ dos cursistas até a fase final deve muito ao acolhimento por parte dos tutores, ao carinho que cada um dedicou. Ainda que a remuneração não cobrisse o tempo dedicado, o tutor estava presente, mesmo que virtualmente. Foram, de certa forma, os pressupostos da educomunicação que sustentaram a interatividade do ambiente virtual de aprendizagem, e não o contrário. O desejo da emancipação, acabou possibilitando o desejo pela relação com a outra pessoa (o cursista). Para isto, era necessário estar aberto ao outro. 


\section{O CONTEÚDO PROGRAMÁTICO DO EDUCOM.TV}

Para que o aluno pudesse refletir e discutir com os tutores sobre a Educomunicação e sobre a linguagem audiovisual, a equipe escreveu e organizou dez tópicos. Cada um tratou de temas específicos, e estes foram coordenados pelos professores Adilson Citelli, Maria Cristina Castilho Costa, Ismar de Oliveira Soares e Marília Franco, em parceria com o grupo de tutores orientados pelos coordenadores, semanalmente.

Em seu conjunto, os dez tópicos se diferenciavam do conteúdo do manual apresentado pela SEED para o programa originário (TV na Escola e os desafios de hoje), levando em conta que estavam centrados mais nas mediações culturais propiciadas pela presença do fenômeno comunicativo na sociedade do que nos pressupostos das tecnologias da informação.

O vínculo com os textos da SEED foi, contudo, mantido pela garantia de acesso aos mesmos por parte dos cursistas, com convites para que fossem lidos e aplicados nos exercícios solicitados.

O primeiro tópico discutiu a Educomunicação e suas áreas de intervenção, apresentando o perfil ideal de um educomunicador. Seu autor, Professor Ismar de Oliveira Soares, busca aproximar os cursistas de experiências práticas no campo da Educomunicação, como é o caso da Fundação Casa Grande - Memorial do Homem Kariri. Preocupado com a resistência por parte dos cursistas ao novo conceito, Soares, já nos primeiros tópicos, argumenta:

Os responsáveis por este curso têm consciência dos problemas que são freqüentemente enfrentados pelos professores e pelas escolas que se preocupam em rever a educação a partir da ótica da comunicação. Entre tais desafios encontram-se, por um lado, o próprio entendimento das teorias que tentam explicar - para além da visão linear das "tecnologias educativas" - as relações vitais que se estabelecem, no mundo contemporâneo, entre as novas tecnologias da informação e o ideário de uma educação capaz de transformar para a cidadania e, por outro, no campo da administração escolar, a superação das resistências que projetos como os analisados ao longo deste texto encontram junto a diretores, coordenadores pedagógicos e membros do corpo docente que vêem neste tipo de esforço uma ameaça à estabilidade dos tradicionais métodos de ensino.

Nossa sugestão é que os professores-cursistas elaborem seus próprios referenciais e encontrem suas próprias razões para aproximar-se do mundo das comunicações e de suas linguagens. O curso tentará ajudar cada um dos professores da rede pública a encontrar suas respostas. ${ }^{207}$

\footnotetext{
${ }^{207}$ Trecho do Tópico do curso Educom.TV, site: hhttp:///www.usp.br/educomtvy
} 
A proposta era que os cursistas refletissem sobre o uso das tecnologias e elaborassem questões sobre o assunto para que estas fossem debatidas com os tutores. Sendo assim, Soares, seguindo os pressupostos educomunicativos, orientava para que a reflexão fosse uma construção e que o cursista participasse dela.

O segundo tópico foi sobre Cultura, consumo e mídia: identificando a cultura midiática de professores e alunos, de autoria da Professora Doutora Maria Cristina Costa Castilho. O objetivo era demonstrar como os meios de comunicação participam da vida das pessoas, na formação do gosto, na construção de identidades e na formação do imaginário. Neste tópico, foi realizada uma pesquisa sobre consumo midiático dos participantes do curso e de seus alunos.

Cristina Costa, ao relacionar consumo, comunicação e cultura, escreve:

E, o que isso tem a ver com comunicação? Acontece que, na sociedade contemporânea, globalizada e pós-industrial, parte do que somos, sentimos ou pensamos decorre do partilhamento de conteúdos aos quais não temos acesso a partir de nossas relações com os outros e com o mundo ou das práticas sociais cotidianas, mas do universo mediado pelos meios de comunicação. Nesse contexto, antes mesmo que uma mãe tenha seu filho nos braços, ela já ouviu seu coração e viu seus bracinhos através de aparelhos de tecnologia sofisticada com os quais é acompanhada a gestação. As primeiras emoções da mãe estão condicionadas a processos complexos de codificação e decodificação de mensagens e dados, a processos comunicacionais, enfim. Do mesmo modo, nossas relações com o mundo estão cada vez mais mediadas por recursos tecnológicos, discursivos e lingüísticos do rádio, da televisão e do computador.

Muitos autores acreditam que esse fato - o de estarmos substituindo nossa relação imediata com o mundo por uma relação mediada pelos meios de comunicação - provoque uma homogeneização cultural capaz de aniquilar diferenças culturais referentes à idade, sexo, classe e religião. Chamam esse processo de massificação. ${ }^{208}$

Costa, além de discutir o consumo, o conceito de cultura e os meios de comunicação de massa, também apresenta um novo recurso que acabava de ser lançado na Internet: o Weblog $^{209}$ ou os atuais Blogs. Um dos exercícios solicitava que cada cursista criasse o seu próprio blog, escrevendo sobre os seus gostos, sua rotina e suas idéias a respeito de programas de TV, filmes, vídeos, artistas e apresentadores que lhes interessassem de alguma forma, isto é: apreciação, críticas ou o despertar de interesses.

No terceiro tópico, já é possível notar que a proposta do curso consistia em estimular o cursista a produzir. Para isso, ele poderia usar os recursos disponíveis da Internet. O conteúdo,

\footnotetext{
${ }^{208}$ Trecho do Tópico do curso Educom.TV, site: ihttp://www.usp.br/educomtvh

${ }^{209}$ Segundo Cristina Costa, a palavra WEB significa "teia" e ajuda a compor a expressão World Wide Web: a WWW como é chamada a rede mundial de computadores. Log, palavra também inglesa, quer dizer diário de bordo. Juntando as duas temos: weblog - diário escrito e publicado na rede por internautas. Disponível em: int
} 
produzido pelas doutoras Maria Cristina Costa e Marília Franco, versava sobre Comunicação, Tecnologia da Informação e Educação. Teve como objetivo, a partir da questão-problema apresentada, provocar uma análise das novas formas de participação. Nesta esfera, surge a pergunta: Como a riqueza da linguagem audiovisual - assim como a interatividade da informática - podem contribuir para que os alunos encontrem novas formas de integração social e de construção de uma nova prática comunicativa?

O tópico adota o conceito de "ecossistema comunicativo" para traduzir um ambiente de ensino/aprendizagem que leva em conta um cenário onde predomina o trabalho em grupo, a narrativa não-linear e uma opção pelo uso democrático e participativo das novas tecnologias. Assim era apresentada uma das áreas de intervenção do campo da Educomunicação, independente de qual fosse a "mediação tecnológica nos espaços educativos".

O tópico quatro teve como título: Aprendendo com textos não-escolares. Numerosas pesquisas foram usadas para constatar que, apesar de esforços isolados, os recursos de comunicação têm estado praticamente ausentes da escola. Baseado no resultado das pesquisas de seu grupo de trabalho, o professor, também coordenador pedagógico do Educom.TV, Adilson Odair Citelli, demonstrou que essa realidade é muito próxima a de vários colégios do sistema público e privado de ensino, mesmo em São Paulo.

O objetivo do tópico foi convidar o cursista a refletir sobre a importância da incorporação, pela escola, das diversas linguagens da comunicação, especialmente a audiovisual, tendo em vista fortalecer as habilidades e competências dos alunos, razão principal de todo o esforço pedagógico. Afirma o texto:

As linguagens não-escolares chegam-nos, fundamentalmente, editadas, o que significa dizer que
foram selecionadas, dispostas segundo níveis de importância, montadas por ordem de interesses,
entendimentos, perspectivas, e dirigidas ao público. Esta operação, de certo modo, irá configurar a
dinâmica dos sentidos que serão ouvidos, lidos ou vistos no rádio, no jornal ou na televisão e
apreendidos segundo variáveis que interferem no âmbito da recepção. O problema, portanto, é menos
o de considerar as realidades que nos chegam, e mais o de verificar quais as estratégias adotadas pelos
veículos de comunicação para compor certos campos de sentidos apresentados como se fossem
extensões do acontecimento. Por isso, é ato de cautela não estabelecermos relações imediatas de causa
e efeito entre o que nos é dado a ver ou ler e os fatos apresentados como plenas expressões da
realidade.

${ }^{210}$ Trecho do Tópico do curso Educom.TV, site: ihttp://WWw. - 
O tópico cinco tratou sobre Características da linguagem audiovisual. O tópico teve como objetivo apresentar a discussão sobre o audiovisual a partir da televisão, sendo esta a principal fonte de informação na sociedade moderna. Portanto, a linguagem audiovisual que vem formando a visão de mundo das novas gerações. Segundo a Professora Doutora Marília Franco, organizadora do tópico, o hábito de receber a comunicação pela TV está reorganizando a forma de expressão das crianças e dos jovens. Frases curtas, elipses e nãolinearidade na expressão do pensamento são algumas das articulações expressivas que as novas gerações estão exercitando, produzindo perplexidade e incompreensão por parte de pais e professores.

Para Franco, é preciso entender que as novas gerações refletem os modelos de seu tempo nas formas de expressão que adotam. Do mesmo modo, a distância que se estabelece no diálogo entre as gerações é também determinada pela carga cultural carregada pelos adultos.

O texto recorda que a escola e os professores estão procurando reduzir essas dificuldades, trazendo para as salas de aula a discussão de vídeos, filmes e programas de TV. Apesar dos grandes progressos já conseguidos, há ainda algumas inquietações que merecem uma reflexão:

\begin{abstract}
Desenvolver a capacidade de leituras plurais das informações com que as mídias nos bombardeiam diariamente torna-se um exercício virtual de cidadania para a vida futura. Aprender a respeitar e a conviver com as diferenças são o grande legado que precisamos deixar para as crianças e jovens. Compreendendo, antes de mais nada, as diferenças, sobretudo de expressão, que já marcam a convivência entre as gerações.
\end{abstract}

A "turma" de hoje não é "incompetente" para escrever. Seus modelos de comunicação são diferentes. Melhores, piores? Impossível definir sem reconhecer as diferenças. Quem sabe a leitura conjunta das linguagens audiovisuais, entre professores e alunos, não ajude a recuperar o respeito mútuo dessas gerações, construindo as bases para um crescimento comum sem o peso autoritário das "verdades" ?211

O tópico seis, de autoria de Ismar de Oliveira Soares, tratou sobre Teorias e práticas da recepção da $T V$. A partir da análise dos gêneros televisivos - telejornal, ficção, programas de auditório, esporte e publicidade - foi abordada a relação do público com a mídia e a realidade que a cerca. O tópico buscou formar o cursista para que ele se tornasse um espectador com atitude ativa e negociadora de sentidos. Neste sentido, desenvolveu conteúdos ligados à área da educação frente aos processos e meios de comunicação, fator que incluiu atividades relacionadas à leitura crítica dos meios, também denominada de media literacy, nos

${ }^{211}$ Trecho do Tópico do curso Educom.TV, site: 
Estados Unidos, ou media education, na Inglaterra. Foi dado relevo à fundamentação teórica que deram sustentação às práticas latino-americanas de recepção organizada, tendo sido propostas atividades que possibilitaram a compreensão mais aprofundada do meio, assim como uma maior familiaridade com seus conceitos e conteúdos.

O tópico sete, também sob a responsabilidade de Soares, teve por título: Planejamento e a relação com a TV Aberta. O objetivo foi o de introduzir o cursista no planejamento educomunicativo. Foi constatado que, ao longo dos últimos anos, os canais de televisão abertos, quer os comerciais quer os culturais ou educativos, vinham ampliando a oferta de produções cuja qualidade estética e cujos conteúdos poderiam merecer a atenção dos educadores pelas oportunidades que ofereciam ao levantar questões para as práticas didáticas, como ilustrar conteúdos escolares ou mesmo introduzir novos temas para debates.

Por intermédio das informações obtidas nos módulos anteriores, o tópico solicitava que o cursista elaborasse uma proposta, tanto de uma leitura competente do material analisado, quanto do uso das produções na sala de aula, tornando a educação mais voltada para a vida cotidiana do educando. As perguntas eram: Como escolher a programação da TV? Como introduzi-la junto aos alunos? Que atividades desenvolver com este material? e como avaliá-las numa perspectiva educomunicativa?

O tópico oito recebeu o título de: Planejando o uso do audiovisual na prática educativa. A oitava reflexão, sob a responsabilidade de Marília Franco, teve como objetivo o ato de repensar o plano pedagógico da escola, introduzindo, de maneira consciente e consistente, o audiovisual nas suas mais diferentes modalidades: cinema, TV, vídeo e multimídia, resguardando suas especificidades. Uma delas é: fazer da linguagem audiovisual um meio efetivo de leitura do mundo e de expressão.

O nono tópico, sob os cuidados de Soares, foi denominado: Planejando a Educomunicação no plano pedagógico. O objetivo do tópico foi introduzir práticas educomunicativas na escola. Para isto, foi necessário: atualização de conhecimentos, capacitação permanente de professores, organização de acervos, organização da infraestrutura e muito planejamento. O tópico propunha preparar não só a classe, mas toda a escola para integrar os meios de comunicação, especialmente a mídia audiovisual, em seu cotidiano. 
O tópico, neste sentido, esteve voltado para uma gestão da comunicação no espaço educativo, buscando a formulação de processos de planejamento, levando em conta as metas estabelecidas pelos Parâmetros Curriculares Nacionais (PCN) para a integração das múltiplas linguagens e suas tecnologias no espaço escolar. Ao final do curso, os projetos foram enviados para avaliação e organizados por temas. Depois do curso, vários projetos foram implementados, sendo que alguns foram premiados, e outros temas se desenvolveram em projetos de mestrado.

O tópico dez, o último, também de Soares (Avaliando os processos de ensino/aprendizagem) tinha como proposição os caminhos para uma avaliação continuada, dele resultando 900 projetos de intervenção, a razão de um projeto por dupla de cursistas. 


\section{OS ENCONTROS PRESENCIAIS E AS IMPRESSÕES NO EDUCOM.TV}

No capítulo anterior, apresentamos os tópicos criados e disponibilizados aos cursistas pelo Ambiente Virtual de Aprendizagem. Como vimos, predominavam os conceitos voltados para o campo da gestão da Educomunicação, em contraposição aos textos da versão original do programa, sob a responsabilidade de uma equipe da SEED/MEC, mais preocupados com o discurso pedagógico sobre as novas tecnologias. No caso, toda a equipe de tutores estava diante de uma novidade, mesmo para eles.

Quanto ao tema específico da relação cultural entre a mídia e o seu consumidor, havia maior diversidade de opinião: enquanto parte da equipe mostrava-se mais seduzida pela recente literatura referente ao denominado campo dos Estudos Culturais latino-americanos ou estudos de recepção, outra parte, com formação em sociologia, dava preferência à questão mais clássica da Indústria Cultural, assim como à crítica ao uso da mídia por uma sociedade economicamente capitalista.

Essa diversidade de pontos de vista refletia na riqueza dos encontros presenciais oferecidos aos cursistas, na cidade de Águas de Lindóia, São Paulo, provocando acaloradas discussões, mesmo entre os coordenadores e os tutores, madrugada adentro, após terminado o período de atendimento ao público. Antes de analisarmos o tema ou os conteúdos, vamos ao tema da pedagogia dos encontros.

\section{Tipos de encontros presenciais}

Para o NCE/USP, encontros presenciais fazem parte da rotina dos curso a distância. No caso do Educom.TV, os encontros foram constituídos por reuniões de formação que ocorreram primeiramente com os articuladores e, posteriormente, com os cursistas. Todas ocorreram na cidade de Águas de Lindóia, no interior do Estado de São Paulo. Durante o 
projeto Educom.TV, a estrutura dos encontros seguia a rotina procedimental do $\mathrm{NCE}^{212}$. No caso, o objetivo era disponibilizar um tempo para o contato com os professores cursistas, por meio de atividades práticas, facilitando o ambiente para que os tutores pudessem conhecê-los melhor a partir dos depoimentos de suas atividades no uso do audiovisual em sala de aula e, por fim, apresentar a proposta da Educomunicação aos profissionais da educação.

O primeiro encontro presencial, numa fase prévia ao início do curso, foi destinado exclusivamente aos Articuladores. O processo teve a duração de cinco dias. Dele participaram os 180 representantes das Delegacias de Ensino (DE) do Estado de São Paulo, além da Equipe da GIP (aproximadamente seis especialistas) e toda a equipe do projeto Educom.TV (45 especialistas, entre coordenadores, tutores e apoio técnico, além da equipe da WBusiness).

O primeiro encontro para Articuladores teve como objetivo teórico apresentar o projeto e introduzir os participantes nas discussões sobre audiovisual sob a perspectiva da Educomunicação, além de apresentar os benefícios da instrumentalização do uso da Internet e, como objetivo prático, treinar os especialistas para darem atendimento aos cursistas em suas respectivas Diretorias de Ensino.

Seguiram-se, a partir do terceiro mês do curso, uma sequência de encontros, na mesma cidade, e com igual duração de 5 dias. Para atender a todos os cursitas, foram realizados quatro grandes encontros. Destacamos que o hotel e todos os seus espaços estavam reservados exclusivamente para os encontros. A qualidade das acomodações eram ótimas, permitindo um efetivo exercício de mergulho no trabalho a ser desenvolvido.

\footnotetext{
${ }^{212}$ O NCE, desde que foi fundado, em 1996, adotou uma estruturam procedimental em suas atividades de formação, incluindo palestras, oficinas práticas, exercícios de planejamento e plenária geral de avaliação. Era na plenária que avaliávamos todo o processo vivenciado. O mesmo esquema pode ser encontrado nos eventos oferecidos pelo NCE, em 1997, no Instituto Cultural Itaú, na fase preparatória para o Congresso organizado pelo NCE, em São Paulo, em 1998, assim como na capacitação dada aos Coordenadores das Escolas Salesianas. O procedimento foi assumido como marca do NCE em seus projetos: Educom.rádio, Educom.Centro-Oeste, Educom.Saúde, Educom.São Luiz, Educom.Geração Cidadã.
} 


\section{A estrutura dos encontros}

A estrutura para os encontros contemplava: Chegada e recepção de boas vindas no primeiro dia ${ }^{213}$, palestras no período da manhã, oficinas no período da tarde e, no último dia, plenária geral. Entretanto, como havia a avaliação de que muitos professores encontraram dificuldades no acesso a Web e no uso do computador, a equipe do projeto solicitou 30 computadores para que, nos intervalos, os cursistas pudessem sanar dúvidas e resolver dificuldades.

Cada encontro presencial para cursistas teve a participação de aproximadamente 650 pessoas, hospedadas em hotel locado especificamente para o projeto pela Secretária de Educação do Estado de São Paulo. Todas as diárias, a alimentação e o transporte foram geridos pela GIP, ficando a cargo da equipe operacional do Educom.TV a parte operacional e pedagógica. Contudo, as estratégias dos encontros sempre foram organizadas conjuntamente pela Secretaria e pelo NCE, guardadas as devidas responsabilidades de cada grupo.

O organograma era o mesmo: palestras, oficinas, trocas de experiências, exercícios de planejamento e avaliação. A equipe da GIP e toda a equipe do NCE - e não apenas os tutores vinculados com as turmas que se reuniam em cada edição da atividade - tomavam parte em cada encontro. As palestras foram ministradas pelos coordenadores, sempre com abertura e acompanhamento da equipe da GIP, representada por um ou mais de seus componentes.

Além do grande auditório, os encontros contavam com a disponibilidade de 19 salas montadas especialmente para atender 35 cursistas por oficina. A equipe operacional teve a tarefa de produzir todo o material didático e organizar as listas e divisões dos cursistas por sala. Ao final de todos os encontros, essa mesma equipe havia criado uma metodologia de trabalho completo sobre gestão de encontros presenciais, definindo as múltiplas variáveis que encontros deste tipo demandavam.

Por causa da ansiedade dos cursistas em conhecer e conversar com o seu tutor pessoalmente, organizamos, logo na chegada, encontros específicos entre cursistas e mediadores. Contudo, como a demanda de horário era restrita, esses encontros acabaram

\footnotetext{
${ }^{213} \mathrm{O}$ primeiro dia era sempre aos domingos por motivo das distâncias e das questões administrativas geridas pela equipe da GIP.
} 
acontecendo no período da noite, durante o jantar ou mesmo depois. Era interessante observar: surpresa, admiração, espanto, alegria e até frustração foram sentimentos expressos e verbalizados pelos cursistas.

Depois do primeiro encontro para cursistas, também percebemos que seria necessário deixar um horário para uma reunião entre os cursistas e a equipe operacional, para sanar problemas tais como: dificuldade na inscrição e dúvidas sobre o projeto.

Durante a parte da manhã, na sala de informática montada pela GIP, enquanto as palestras aconteciam, os tutores atendiam os cursistas que necessitavam de especial atenção. Durante o almoço e o jantar, os tutores e a equipe operacional se revezavam atendendo os cursistas que tinham dificuldade em acessar o ambiente virtual, pois lá estavam as lições e os exercícios. Para isso, levávamos também o material impresso. Essa demanda intensa permaneceu até o último encontro.

\section{A Rotina}

A rotina era intensa. Tomávamos café da manhã, almoçávamos e jantávamos com os cursistas. Nas poucas horas de intervalo entre o jantar e a reunião da equipe - que sempre acontecia às 22:30h - nos encontrávamos com os cursistas para jogar bola, nadar nas piscinas aquecidas ou cantar em torno de alguém que tocava violão. Muitas vezes, fazíamos a reunião do grupo do NCE e voltávamos para a roda de violão, já que as áreas esportivas fechavam às 22:00h. A última ação da equipe, a cada dia, era a reunião geral de avaliação que nos mantinha acordados até às 2 da madrugada (quando não até mais tarde).

Os trabalhos começavam oficialmente às $8: 30 \mathrm{~h}$ e terminavam praticamente à 1:00h da madrugada. Após o encontro entre tutores e cursistas, a equipe toda se reunia para avaliar o dia. Eram quatro dias intensos e cansativos que se tornavam gratificantes, lúdicos e alegres, principalmente no penúltimo dia da confraternização. 
Era na confraternização que os sorrisos se tornavam espontâneos, a distância estava rompida, e a proposta de companheirismo entre todos se estabelecia. Com toda a certeza, a “confraternização" fez parte do sucesso pedagógico do projeto.

A confraternização acontecia no penúltimo dia, porque no último a equipe saía logo após a plenária geral de avaliação e conclusão, que, no projeto, foi denominada de: "Painel de encerramento". O painel de encerramento consistia na sistematização e avaliação do encontro. Como relatamos, tivemos quatro desses megaencontros.

\section{As palestras}

No auditório, eram apresentadas as palestras que tiveram como títulos: Educando com os textos não escolares; Planejando a Educomunicação; O audiovisual no processo educativo; Planejando a educomunicação com os vídeos da TV Escola. Tais palestras abordavam as discussões da Comunicação e suas áreas específicas, tais como: a mediação tecnológica, as novas linguagens na educação, o processo de significação da imagem, o processo lúdico do audiovisual, as competências na educação, os ecossistemas comunicativos, a interatividade, o receptor no processo de comunicação, o encontro e desencontro das gerações no uso das novas tecnologias, o acervo e o uso da TV Escola e principalmente a Educomunicação.

Todas as palestras foram oferecidas com apresentação de algum vídeo ou transparência. Os palestrantes, apesar de estarem frente a um grupo com mais de 600 pessoas, independentemente do conteúdo, sempre tinham como objetivo tentar aproximar os cursistas de maneira acolhedora, fazendo uso do audiovisual.

O grupo do NCE tinha a intenção de que tanto as palestras como as oficinas fossem agradáveis, sedutoras e envolventes. A proposta consistia em apresentar a educomunicação sendo educomunicativo. ${ }^{214}$ Neste sentido, uma palestra e duas oficinas tiveram nomes

\footnotetext{
${ }^{214} \mathrm{Na}$ época do projeto, Soares postulava que a Educomunicação discute a necessidade de introduzir, nas práticas educativas, todas as estratégias desenvolvidas pela comunicação e pelos comunicadores. Por isso, os educadores deveriam ser principalmente comunicadores alegres e extrovertidos. Deveriam ser comprometidos, porém não pessoas distantes e autoritárias.
} 
"fantasia". ("Por um feriado que não acabe nunca", "Horário Nobre" e "No escurinho do cinema"). O objetivo foi despertar nos cursistas a curiosidade para com o tema da palestra ou para a prática que seria desenvolvida na oficina.

\section{As oficinas}

Em 19 salas diferentes, os cursistas eram atendidos, em grupos de 35, por uma dupla de mediadores/tutores, que, para tanto, haviam se preparado nas semanas anteriores, na ECA/USP.

Cada oficina, nos encontros presenciais, foi um espaço exclusivo durante o encontro. Mesmo que os temas fossem os mesmos, cada dupla de tutor e cada grupo vivenciou momentos específicos. Isto pode ser notado nos relatos escritos pelos mediadores e nos depoimentos dos cursistas no ambiente virtual.

As oficinas foram preparadas com antecedência. Os tutores, em parceria com os coordenadores educomunicacionais chegaram a formular mais de 25 modelos a serem trabalhados em cada um dos encontros. Porém, o nosso grupo avaliou que seria melhor concentrar as práticas educomunicativas em três oficinas: uma primeira que teria como proposta a discussão do uso e da importância do audiovisual em práticas educativas; uma segunda que demonstraria a importância da quebra de alguns preconceitos com relação ao uso de peças audiovisuais em sala de aula (que foi considerada também como retomada da discussão de valores e conceitos em torno do uso de produções - como as novelas - em sala de aula, envolvendo a dicotomia entre estudos culturais e indústria cultural) e, por fim, uma terceira oficina voltada para o planejamento educomunicativo (como aplicar os conceitos do curso na realidade dada de cada instituição escolar). 


\section{Painel de encerramento}

O painel de encerramento do encontro era precedido por uma preparação dos cursistas nas salas reservadas para as oficinas. Lá era escolhida uma pergunta, e um cursista era indicado para representar o grupo apresentando a questão no "Painel de Encerramento". Muitas questões abordavam temas como: audiovisual, novas tecnológicas, novas linguagens e práticas pedagógicas. No painel, um dos coordenadores pedagógicos em parceria com a coordenadora operacional respondia as questões tanto de ordem pedagógica, operacional, como, principalmente, sobre a própria Educomunicação.

Todo o trabalho do painel de encerramento era sempre acompanhado pelos componentes da equipe da GIP que também, quando solicitados, respondiam questões ligadas à Secretária de Educação e aos projetos desenvolvidos e geridos por eles.

\section{O Intraduzível}

Os cursistas, quando chegavam ao hotel, observavam as dependências do lugar e se mostravam maravilhados. Alguns chegavam a verbalizar que nunca haviam sido tão bem tratados. A equipe da GIP avaliava de maneira competente que os professores da rede deveriam ser respeitados e bem tratados. A forma de mostrar isso era oferecer conforto e qualidade, visto que o grupo passava quase uma semana fora de casa.

A atitude da equipe da GIP na preparação, desenvolvimento e avaliação dos encontros eram pouco comuns em atividades desta natureza. Pela experiência adquirida em outros projetos, percebemos que tudo que se destina a professores do ensino fundamental e médio é tratado com pouco esmero. Não era este absolutamente o caso da relação entre a GIP e os cursistas do Educom.TV e com a equipe do NCE/USP. O hotel destinado aos encontros presenciais era da categoria "cinco estrelas" e disponibilizava toda a sua infra-estrutura para os cursistas: restaurante, piscinas aquecidas, saunas, quadras, sala de jogos e sala de ginástica. 
Entretanto, as atividades do curso eram tantas que não sobrava muito tempo para usar todas as instalações. Mesmo assim, o ambiente facilitou a confraternização entre todos.

Não é difícil descrever as atividades dos encontros presenciais. O que é quase intraduzível em palavras são os "encontros" afetivos que propiciavam uma convivência amigável e respeitosa entre todos os participantes. O que tentaremos descrever é uma pequena representação do muito que compartilhamos e vivenciamos em Águas de Lindóia.

\section{Os Mediadores/Tutores}

Parte do sucesso do empreendimento se deve aos Mediadores/Tutores. Todos entregavam relatórios mensais sobre suas atividades. Por meio dos relatos, os coordenadores orientavam as atividades seguintes. Apresentaremos, a seguir, um trecho do relatório de Lara Cristina Lourenço Deppe que demonstra quão intensas eram as atividades e como envolvidos estavam os colaboradores no processo.

A partir do mês de junho, as atividades entraram no esquema previamente estabelecido, com exceção da semana do dia 10 ao 14, que foi logo após o Encontro Presencial e se caracterizou por ser uma semana preparatória para o início dos atendimentos aos cursistas. Após esta semana, começamos a vivenciar o dia a dia do curso, seus problemas e progressos em uma rotina já demarcada.

Como dito no relatório do mês de maio, a reunião geral do dia 10 de junho teve como pauta avaliar o resultado do Encontro. Nela, também tivemos retorno dos articulistas sobre as atividades desenvolvidas. Nesta primeira semana, participei também da reunião em grupo sobre o tópico 3, sob a orientação da Profa. Dra. Maria Cristina C. Costa, dando continuidade às atividades desenvolvidas em maio. Nela, debatemos sobre o texto-motivador preparado pela Profa. Maria Cristina e repartimos atividades individuais a serem desenvolvidas como complemento ao texto, tais como arranjar imagens, sites da internet para a sitiografia, referências bibliográficas e elaborar explicações de conceitos presentes no texto com a finalidade de criar um glossário explicativo do mesmo. Fiquei com os conceitos de 'Indústria Cultural' e 'Cibercultura', me apoiando nos textos abaixo relacionados: bibliografia:

COELHO, Teixeira. O Que é Indústria Cultural? São Paulo: Editora brasiliense, 1980.

LIMA, Luiz Costa. Teoria da Cultura de Massa. São Paulo: Paz e Terra, 1990.

MARCONDES FILHO, Ciro. Superciber: a civilização místico-tecnológica do século 21. São Paulo: Ática/ECA-USP, 2000.

LÉVY, Pierre. Cibercultura. São Paulo: Editora 34, 2001.

No dia 17 de junho, segunda feira, reunião geral. Nela, recebemos as últimas diretrizes sobre o que fazer quando no primeiro dia de atendimento, o dia seguinte. No meu caso específico, só havia uma pergunta a responder, de uma aluna querendo saber sobre quando deveria enviar seu exercício. Por outro lado, no entanto, vários foram os problemas no manuseio do site que ficaram evidentes desde o primeiro dia, dentre eles, por exemplo, como responder a pergunta da aluna. Tais problemas foram e estão sendo recorrentes e têm impedido o atendimento correto ao aluno. Um dos principais, que foi resolvido há pouco tempo, foi a impossibilidade do aluno reenviar os exercícios com a mudança solicitada. Mesmo que este já tenha sido resolvido, um outro continua quebrando as "cabeças tutoriais": o fato de que nós, tutores, não podermos virtualmente distinguir entre enviar o exercício com sugestões e observações ao aluno e considerá-lo satisfatório para arquivo no banco de dados. 
De qualquer maneira, muito do atendimento foi prejudicado por estes problemas técnicos. As segunda e terceira semanas de atendimento na FDE (meu horário é terça e quinta-feira pela manhã) foram prejudicadas pelo fato de que tínhamos que resolver mais problemas com as inscrições de nossos cursistas, tais como e-mail errado, senha não recebida e inscrições indevidas, o que acabou acumulando os exercícios para as semanas que se seguiram, sendo que estes problemas ainda não foram totalmente resolvidos. Ainda aguardo duas respostas de articulistas sobre a confirmação dos inscritos em suas diretorias e ainda tenho pessoas que não acessaram o curso, as quais continuo a perseguir.

A semana seguinte ( 24 a 28 de junho), portanto, seguiu a programação estipulada para atendimento (terças e quintas na FDE e quartas em casa), reunião com os tutores (segundas), reunião pedagógica com os coordenadores (segundas à tarde) e reuniões para a elaboração do tópico 3 (definida a cada semana), as quais, no entanto, aconteceram fora do tempo previsto para participação na tutoria. De maneira geral, discutimos, nas reuniões gerais, textos a serem lançados ao ar, problemas técnicos e próximas oficinas; nas orientações pedagógicas, sobre como agir com os cursistas, sendo proposto que se lançasse uma questão no Fórum, aproveitando o clima da copa: "É o Felipão um educomunicador?", e foram tiradas observações a serem levadas para a reunião entre os coordenadores; e na reunião sobre o tópico 3, como já mencionado, foi estabelecida a contribuição de cada um pertencente ao grupo para enriquecer o conteúdo do texto-motivador, que versa sobre história dos meios de comunicação de massa e tecnologias e apontando para as diferenças entre tecnologias analógicas e digitais.

Até o momento foram corrigidos 23 exercícios referentes ao tópico 1 e respondidas 13 perguntas, cujos temas eram bem específicos, como prazos, dificuldades etc. De forma geral, os exercícios se mostraram cada vez mais elaborados, pois os primeiros eram escritos com descaso e pressa, enquanto nos últimos percebe-se que os cursistas pensaram um pouco mais para respondê-los. Tenho geralmente respondido com mais perguntas para aprofundar a idéia de educomunicação do que soluções, instruindo para que eles me enviem de volta com mais reflexão a respeito do conceito. Esta estratégia é, também, uma solução temporária para o fato de que não posso simplesmente aceitá-lo, pois não há a possibilidade de se distinguir, na página, quando o exercício precisa de revisão e quando ele já está satisfatório. Uma dificuldade técnica que já foi mencionada, anotada e enviada.

Poucas pessoas me enviaram os exercícios de volta com as correções, mas já percebi que elas tendem a responder diretamente as minhas perguntas, sem necessariamente reelaborar a sua primeira resposta, como eu havia imaginado que fariam. A solução seria que os exercícios viessem com a primeira resposta, a observação e a segunda resposta em sequiência, de forma a criar um diálogo com o aluno que aperfeiçoasse a compreensão do tópico. Outro problema apresentado é o fórum da sala específica. Lancei a seguinte pergunta no ar: "Seria o Felipão um educomunicador?" e, embora as respostas tivessem sido bem interessantes, elas se dirigiam especificamente à minha pergunta, unilateralmente, sem que se criasse um ambiente virtual de discussão entre todos os participantes. Este é um problema de concepção do fórum que precisa ser resolvido, pois ainda não sei como irei driblá-lo, já que não quero dar uma resposta a todos, pois irei fugir do escopo do ambiente criado. Tentarei, provavelmente, elaborar uma visão geral das respostas e lançá-la no ar. Embora seja este o papel de mediadora, ainda assim faltam ferramentas que me possibilitem criar um ambiente de discussão ideal.

Por outro lado, faz-se urgente que os espaços do "ambiente" sejam definidos, porque é preciso que eu saiba exatamente onde jogar as informações e suscitar as reuniões. Embora isto seja uma questão de bom senso, alguns cursistas confundiram local apropriado para determinadas coisas, como é o exemplo de uma que escreveu em seu exercício que a outra inscrita de sua escola não havia recebido sua senha ainda. Como a correção foi prejudicada graças às inscrições, demorei uma semana para receber o recado e, portanto, uma semana para resolver o problema. Urge que se especifique os ambientes para que nós, tutores, possamos passar para os nossos cursistas. Eu mesma, por exemplo, tive dificuldades em saber se deveria mandar dúvidas pelo fórum dos tutores ou pelo e-groups. $\mathrm{Ou}$ seja, qual o papel do fórum, qual o papel do e-groups, qual a sua diferença? Acredito que essas questões vão se tornando cada vez mais complexas na medida em que os cursistas e tutores começarem a ter maior intimidade com os espaços disponíveis. Até agora, poucos se aventuraram, mas e depois?

Como última dificuldade encontrada, não sei bem se os exercícios cumpriram o desejado. Pois a forma como foram elaborados deixou muito em aberto qualquer resposta, sem que fosse necessária referência direta ao texto. Ou seja, várias respostas poderiam ter sido dadas sem que a pessoa tivesse mínima idéia do que é educomunicação. Um sintoma disso foi o fato de que tendeu-se a enumerar experiências de introdução de vídeos, jornais, revistas, internet em sala de aula, sem se discutir o método desta introdução. Fiz, por isso, questão de fazer perguntas que motivassem o cursista a retomar o conceito, a pensar um pouco a respeito do papel do professor em sala de aula e etc. 
Fora tudo o que foi mencionado, acho que a cada dia que passa o trabalho fica mais gostoso!!!

\section{Entre o Presencial e o a Distância}

Os encontros presenciais para cursistas, com certeza, foram responsáveis pelo vínculo estabelecido entre os cursistas e os mediadores/tutores. Após os encontros, os e-mails para os tutores aumentaram, assim como também foi maior a participação dos cursistas no fórum e nas respostas dos exercícios. O tratamento entre cursista e tutores melhorou, e as relações se estreitaram.

Contudo, o sucesso dos Encontros Presenciais e o vínculo que se estabeleceu entre todos não nos impede de repensar algumas questões tais como:

- Seria possível ter um curso sobre o uso do audiovisual na escola, a partir dos pressupostos da Educomunicação sem encontros presenciais, com o mesmo índice de freqüência?

- Os encontros presenciais seriam estratégias para o ingresso e envolvimento do cursista no ambiente virtual?

- Apenas o ambiente virtual consegue garantir o vínculo entre tutor e cursista?

Os índices nos demonstram que o Educom.TV foi um sucesso. Para nós, o sucesso deve ser atribuído ao envolvimento de toda a equipe, mas também aos encontros presenciais. Foram os Encontros Presenciais que possibilitaram a aproximação com os cursistas, ainda que o curso todo fosse considerado uma grande experiência para validar a formação continuada de educadores por meio da educação a distância.

Os encontros presenciais nos ofereceram a oportunidade de perceber os cursistas e dar respostas muito rápidas. Acreditamos que a nossa cultura ainda é do toque, do sorriso, do abraço e, principalmente, do olhar. Um dos momentos mais "aquecidos" dos Encontros Presenciais, por exemplo, foram as reuniões de confraternização. Como realizar a confraternização a distância? É na confraternização que nos soltamos, rimos, brincamos, enfim, nos confraternizamos. 
O presencial possibilitou também que os tutores e a equipe operacional pudessem perceber qual cursista apresentava dificuldade - para não dizer medo - em acessar o ambiente virtual, sem que ele precisasse explicitamente dizer ou escrever sobre isso. Foi por intermédio desta constatação que carinhosamente o tutor pôde sentar e, "passo a passo", conduzir o cursista ao acesso do ambiente virtual. Alguns cursistas sentiam constrangimento em contar que, apesar da atualidade, não sabiam nem ligar o computador.

O primeiro grande desafio foi quebrar a barreira de se expor em relação ao computador, ao uso da internet, à dificuldade de acesso, aos problemas educacionais e estruturais e até aos problemas pessoais de formação. Foi no presencial também que percebemos e ouvimos os comentários e as experiências dos cursistas, sem que as falas tivessem necessidade de serem mediadas pela escrita - que necessita de uma lógica e estrutura específica.

A educação não pressupõe apenas procedimentos lógicos ou lineares. A educação também se faz pela percepção, pelo envolvimento, por aquilo que me seduz e me envolve. Foi, por exemplo, numa das práticas dirigidas por Marília Franco, denominada "no escurinho do cinema”, que convivemos com as lembranças e emoções dos participantes. Foi nela que todos nós também nos emocionamos com os cursistas, lado a lado. Ouvimos suas histórias, suas lembranças e até algumas mágoas e realizações.

O ambiente virtual garantiu as respostas e o acompanhamento dos tópicos, dos exercícios e, principalmente, dos comentários dos cursistas. O presencial teve o papel de vínculo afetivo de "encontro". Este foi o fenômeno educomunicativo que presenciamos, sentimos na pele e principalmente no coração, durante o projeto Educom.TV. A mesma sensação se repetiu nos projetos Educom: Rádio, Educom.Saúde, Educom.Geração-Cidadã, Educomradio.Centro-Oeste - que foram projetos dos quais participamos - e, por último, no programa de educomunicação socioambiental do Ministério do Meio Ambiente. Que fenômeno é esse? De que se trata?

Os encontros presenciais propiciaram a possibilidade do "encontro", entre pessoas diferentes, entre outras formas de apreensão da realidade. Ao trabalhar com a linguagem audiovisual, com o afetivo e com o lúdico, as pessoas abriram mão de estratégias, de disputas acirradas e se permitiram conversar. 
A oficina "no escurinho do cinema", por exemplo, era um espaço onde as pessoas relatavam suas percepções sobre o filme que mais havia marcao a própria vida, que lembrança estava guardada. O objetivo, no entanto, não era fazer uma análise crítica do filme, mas deixar com que a pessoa relatasse "que elemento" no filme a tocou, o que a fez sorrir ou chorar.

A oficina que tinha, por intuito, reconhecer o que nos toca, fora da ordem do racional, fez com que nos abríssemos ao relato da outra pessoa. Estávamos fechados em nós mesmo e não sabíamos. 


\section{CONSIDERAÇÕES QUE ATRAVESSAM}

Quando iniciamos a pesquisa Pelos caminhos de Alice: vivências na Educomunicação e a dialogicidade no Educom.TV sabíamos que o estudo seria um processo de nossa inserção no campo da Comunicação e da Educomunicação, e não simplesmente a busca de um produto final.

Tomamos a pesquisa como um processo. É neste espírito que retomamos os pontos principais, não com o objetivo de encerrar ou concluir. A idéia também era manter o objetivo de abrir pontos a serem estudados ou fazer novas perguntas.

Quando começamos o trabalho, tínhamos uma grande pergunta: o que é a Educomunicação? A questão parecia insólita, já que trabalhávamos no setor com o pesquisador que sistematizou e propôs que a área é um campo emergente de intervenção social.

O nosso objetivo não era investigar a existência ou não do campo, já que participamos da pesquisa Perfil e constatamos que existia um novo ofício ou outra forma de entender as práticas comunicativas. Além disso, também trabalhamos no NCE desde sua fundação. Por outro lado, queríamos entender o que significava Educomunicação.

Acompanhando os estudos e discussões no Filocom, percebemos que Ciro Marcondes Filho dá grande ênfase ao estudo da comunicação. O objetivo do professor não é especificamente realizar a pesquisa para a defesa da existência do campo ou para definir o objeto do campo. Ele deseja, filosoficamente, refletir sobre o que é a própria comunicação.

Marcondes Filho nos fez perceber que comunicação não são meios de comunicação de massa, aparatos tecnológicos ou informação. Comunicação é um "Acontecimento", algo que nos toca na esfera dos sentidos e não dos significados. Não é o que "eu entendo", mas o que "mexeu comigo", "o que me modificou”, algo que intensamente me transforma.

Para estudar a comunicação ou o "acontecimento", Marcondes Filho foi a fundo nos estudos epistemológicos, questionando a ciência racionalista e a sua metodologia. A criação da abordagem denominada metáporos, como foi possível acompanhar, é uma proposta para viabilizar pesquisas durante o "acontecimento", ou seja, durante a comunicação. Esta idéia se 
justifica principalmente porque entendemos que o objeto é fugidio, imprevisível e não avisa quando vai ocorrer.

Acompanhando os estudos de Marcondes Filho, assumimos que, para nós, a Educomunicação é muito mais do que ensinar o uso dos meios em ambientes de educação formal ou não formal. A nossa intuição já nos alertava que o uso dos meios era um caminho, mas não era a Educomunicação em si. Sendo assim, o que é a Educomunicação?

Assumimos o metáporos para tentar ver "esse algo novo" que acontece em atividades educomunicativas, para então acalmar uma angústia pessoal. Isto porque não nos contentávamos com as respostas existentes.

A princípio, nossa hipótese apontava que a Educomunicação possuía a capacidade de emancipar. Ou, para usar um termo mais contemporâneo, este campo de atuação seria capaz de garantir a autonomia. Foi para identificar a característica política que rastreamos o surgimento do que poderia ser a fonte da Educomunicação no Brasil.

Acreditávamos que a polarização "capitalismo versus comunismo" e posteriormente a forte repressão exercida pelos governos autoritários, no Brasil pós 1968, fossem a principal causa do surgimento de práticas educomunicativas. Atualmente, reconhecemos que estávamos influenciados pelo esquema "causa-efeito" das ciências objetivas.

Por outro lado, a mobilização em torno da UCBC e do projeto LCC foi fruto de resistência ao governo da época e da forte pressão política exercida sobre os meios de comunicação de massa. Neste sentido, ensinar a ler os meios era uma possibilidade para que a população soubesse o que estava acontecendo no país.

A academia e os estudos pós 1968 apontavam para a tomada de consciência pela razão. Mesmo a Escola de Frankfurt, tendo realizado estudos sobre o esclarecimento e denunciando a sua instrumentalização, o caminho ainda consistia na busca da autonomia pela racionalidade.

A medida que a pesquisa avançava (por exemplo, quando estudamos a comunicação popular) mais acreditávamos que o caminho da Educomunicação era a emancipação e a tomada de consciência política da classe trabalhadora. A Educomunicação, nesta perspectiva, teria como pressuposto libertar os trabalhadores pelo esclarecimento. 
Com as discussões sobre o "campo emergente", a nossa questão específica se confundia com o reconhecimento do campo e com a percepção de um fenômeno que vivenciávamos e não sabíamos o que era. Foi retomando os estudos do surgimento do campo e principalmente resgatando o trabalho de Mário Kaplún que conseguimos compreender que uma parte da discussão diz respeito à legitimação da área como ofício ou como uma graduação em formação; a outra consiste na questão do que é o fenômeno educomuicativo.

Foi acompanhando as discussões do campo da comunicação que percebemos que a Educomunicação vive o mesmo dilema. Campo, objeto, fenômeno e práticas. Porém, todas estas questões só ficaram menos obscuras quando estudamos o que é a emancipação e o esclarecimento, ou seja, quando percebemos que existem discussões na filosofia do conhecimento sobre o que é conhecer ou como se conhece o objeto.

A maior parte dos trabalhos da comunicação popular e da Educomunicação estão orientados para a tomada de consciência racionalista. Contudo, paradoxalmente, o fenômeno educomunicativo é totalmente afetivo, emocional, algo que acontece.

Soares sempre afirmou que a Educomunicação é a possibilidade de "implantar", ao que diríamos: "abrir espaços" para o diálogo franco e aberto. Foi por isto e pelo diálogo que fomos tentando cercar o fenômeno. O rastreamento do termo nos fez chegar a Martin Buber e posteriormente a Lévinas.

Confirmamos a noção de que a Educomunicação é um campo ou uma área com diferentes práticas sociais. Aprendemos que estamos diante de um fenômeno que se define, essencialmente, pela sua condição de dialogicidade.

O campo da Educomunicação consiste em espaços de relações que, na prática do NCE/USP, vem se traduzindo em pesquisas, projetos de formação, seminários e congressos. O presente trabalho constitui uma parte das pesquisas próprias da área da reflexão em torno da Educomunicação. A presente tese está somada às pesquisas já apresentadas sob os cuidados de Patrícia Horta Alves, Marciel Consani, Renato Tavares Filho, Cláudia Funari e Maria Izabel Leão, para lembrar apenas os que desenvolveram pesquisas sobre o próprio trabalho do NCE, no espaço do programa de pós-graduação da ECA/USP. 
Os trabalhos que nos precederam voltaram-se para a descrição da prática educomunicativa, com a tentativa de sistematizá-la. O nosso estudo permanece no mesmo objeto, mas sob outro ângulo: não nos preocupamos com o "campo", mas com o "fenômeno".

E o que percebemos?

A pesquisa demonstrou que o diálogo representa a essência da virtualidade do conceito e da prática educomunicativa. A Educomunicação existe por causa do diálogo; vive dele e para ele tende, continuamente.

O diálogo, contudo, na Educomunicação, não é simplesmente a troca ou o compartilhamento de idéias entre pessoas para se chegar a algum consenso. Não é o diálogo da perspectiva racionalista. O diálogo educomunicativo, caracterizado como franco e aberto, é o espaço do "entre", em que a expressão se encontra, o espaço proferido pela palavraprincípio "Eu-Tu”, descrita por Buber.

Para que o diálogo ocorra é preciso que o Eu se reconheça como Tu. Proferir a palavra-princípio "Eu-Tu" tem, neste sentido, sua natural contrapartida ética. Significa tratar a outra pessoa como ser humano, com toda a sua presença corpórea e sua dignidade, ao contrário do que ocorre quando estabeleço a relação do "Eu-Isso", em que o "Isso" não passa objetivamente de uma "coisa".

Durante o projeto Educom.TV, percebemos que a aproximação entre os mediadores/tutores e os cursistas os colocava em relação, numa relação dialógica, ambiente em que o novo poderia surgir. Percebemos, ao descrever os encontros presenciais do Educom.TV, que a intenção dos agentes do processo era a de criar a ambiência, para que algo acontecesse. A intenção não é “comunicar pelo diálogo”, mas criar espaços para o Diálogo.

Não sabíamos muito bem como pesquisar algo que avançava para além dos processos racionalistas, algo que era percebido como pura sensação. Entretanto, durante a pesquisa, notamos que não se tratava de uma questão restrita de metodologia, mas, sim, de algo referente a paradigmas.

Durante o Educom.TV, tivemos a ocasião de testemunhar o comportamento de alguns mediadores/tutores numa atitude de abertura e acolhida para com a outra pessoa na sua diferença, na sua infinitude, sem manifestar o desejo de dominar ou convencer. Proferiram a 
palavra-princípio "Eu-Tu" e não "Eu-Isso", ultrapassaram o que chamamos de profissionalismo. O diálogo no Educom.TV aconteceu.

O Educom.TV criou espaços para o diálogo. Contudo, é interessante observar que, na maior parte das vezes, acabamos nem percebendo. O diálogo franco e aberto ocorreu. Entretanto, por ser tão estranho soava como algo místico.

Não estamos falando do diálogo que busca o consenso ou que permite que cada um fale organizadamente, mesmo que sem hierarquias. Também não estamos nos referindo àquele que busca uma verdade absoluta. Estamos falando do diálogo aberto, com verdades provisórias, aceitando idéias que sejam concebidas por todos, e admitindo, mesmo quando essas são divergentes, que os resultados permaneçam igualmente abertos, algo que, durante o Educom.TV, chamamos de momento mágico, pois não sabíamos explicar.

Passamos, então, além de perceber, entender o que Soares afirma, em suas palestras aos cursistas: que os pressupostos da Educomunicação são válidos quando seus praticantes aceitam construir o diálogo franco e aberto. Aberto sem intencionalidades ideológicas e muito menos políticas, ou seja, sem a intenção de "converter", "fazer a cabeça”, “conscientizar", "emancipar".

O fenômeno que vivenciamos durante o projeto do Educom.TV e que vimos acontecer ocorreu entre tutores/mediadores e cursistas, no espaço do "entre". Foi do "entre" que as palavras surgiram, mas foram mais que palavras: também foram espaços, pausas carregadas de sensações, de lembranças.

Durante uma das oficinas, um cursista tomava coragem e começava a falar. De repente, outro e mais outro. Quando percebemos, vários falavam enquanto outros ouviam. $\mathrm{O}$ tutor não era um condutor ou um líder. Estava em relação "Eu-Tu", e o cursista não era um "Isso". As falas expandiam as opiniões, mesmo quando algumas apresentavam oposições ao pensamento hegemônico no grupo.

O Educom.TV não foi um sucesso pela quantidade de pessoas que participaram, mas pela dialogicidade que nele se realizou, um diálogo promovido principalmente nas oficinas e em alguns encontros presenciais pontuais e que abriu espaços para que as pessoas ouvirem e colocarem as suas idéias em suspensão, sem hierarquias e principalmente sem pretensões de se chegar a uma única verdade final. 
Seguindo o pensamento de Ciro Marcondes Filho, adotamos o princípio de que é necessário aprender a narrar a experiência sem, contudo, tentar encontrar suas causas, efeitos ou justificativas: Devemos simplesmente "deixar que o fenômeno se apresente aos sentidos" tarefa difícil, já que a nossa formação acadêmica é orientada para buscar os motivos, dar justificativas e, principalmente, chegar a verdades, assim como a resultados concretos e conclusivos.

Começamos, assim, a observar os diálogos nos projetos desenvolvidos pelo NCE e, com mais atenção, no Educom.TV, pois eles estabeleciam relações. Os cursistas se sentiam tão à vontade e tão próximos dos tutores que a "amizade" continuava pelo intermédio do Ambiente Virtual de Aprendizagem.

A forma como alguns tutores se relacionaram com os cursistas foi fator fundamental para que a relação ocorresse. Segundo o relato da tutora Ademilde Sartori, especialista em educação a distância, alguns vínculos ficaram tão fortes que ela ainda troca e-mails com cursistas do Educom.TV, realizado em 2002.

A Educomunicação é um processo pelo qual a relação se estabelece quando o tutor/mediador é um "Eu" que é um "Tu" e se relaciona com a outra pessoa também como "Tu". Novamente vemos a relação "Eu-Tu" promovendo o diálogo franco e aberto por meio da comunicação irradiada ou não.

Na área da Comunicação, somos programados a pensar que comunicação são meios. Mas comunicação não são meios e nem se realiza por eles. É no entre que tudo acontece, no incorpóreo: corpo sem órgãos, todo o caminho ainda a seguir e a descobrir: Metáporos, fenomenologia da educomunicação.

Segundo Buber, um dos aspectos fundamentais da vida de nossa comunidade sobre o qual podemos agir a fim de tornar a paz vital mais próxima é a educação. Mas, para isso, a atividade educativa tem que ser cuidadosamente distinguida do que ele nomeou de propaganda. "O propagandista não tem nenhum interesse real pelo homem sobre o qual deseja influir; suas qualidades individuais só o interessam na medida em que delas se pode servir para nele inculcar sua 'mensagem'., 215

\footnotetext{
${ }^{215}$ Martin BUBER, apud. Marcelo DASCAL, A idéia de paz na filosofia de Martin Buber. In: BUBER, Martin. Do diálogo e do dialógico, São Paulo, Perspectiva, 2007, p.26.
} 
A educomunicação, quando surgiu no cenário nacional, estava completamente envolvida com as questões políticas de sua época, como vimos no segundo capítulo. Entretanto, os trabalhos realizados por meio do que chamamos de práticas educomunicativas acabaram sempre por promover o diálogo. Fator que acabou possibilitando a expressão e o desenvolvimento das capacidades individuais.

Ao se propor facilitar espaços dialógicos, a educomunicação não deve cair na armadilha da racionalidade, levando para a discussão o exercício do que chamamos na academia de “instrumentos de elaboração do saber”: capacidade de sintetizar, analisar, criar inferências e conclusões. Estes servem para outro momento. O exercício educomunicativo está na mística, na sensação, na percepção do outro.

O verdadeiro educador, para Buber, tem por objetivo básico o desenvolvimento das qualidades individuais do educando. Sabemos que isto não é possível por meio da imposição da nossa vontade e das nossas idéias sobre o outro. Trata-se de uma tarefa difícil de ser exercida, contudo, necessária. Por isso, a aposta no diálogo franco e aberto.

Foi o reconhecimento do outro como Outro, com todas as suas diferenças e na busca por potencializar as qualidades individuais que o tutor/mediador, durante o Educom.TV, conseguiu promover o diálogo. Esta é a grande lição: potencializar as qualidades, deixar que o diálogo aconteça.

As práticas educomunicativas não seguem práticas propagandistas como nomeia Buber. São práticas dialógicas e, quando instrumentalizadas, caem na armadilha racionalista. Por isso, a auto-percepção e a percepção do outro são chaves, caminhos de entrada para a relação "Eu-Tu” e, por fim, para a consciência do Eu.

A dicotomia propaganda vs. Educação corresponde à oposição política $v s$. Social. Enquanto que o propagandista de um partido ou de uma instituição governamental qualquer intenciona "inculcar no público uma vontade pré-fabricada, isto é, implantar em cada um a certeza de que essa é sua própria vontade, nascida em seu próprio seio", a intenção da educação social é "despertar e desenvolver em cada um dos educandos a espontaneidade da sociabilidade, que existe potencialmente em todos nós, e que é perfeitamente compatível com a vivência e a reflexão individual"216

É no cerne da alma individual que devemos processar a transformação básica. Isto não quer dizer voltar-se a si mesmo completamente e se transformar em asceta, diz Buber.

\footnotetext{
${ }^{216}$ Martin BUBER, 1965, p. 413, apud. Marcelo DASCAL, Ibid., p. 27.
} 
Dentre a pluralidade de componentes positivos que descobre em sua alma encontra-se a tendência a voltar-se para o outro, o "instinto de comunicação"; é então que ele aprende a "dizer-tu" e, a partir daí, a dizer "Nós". E só aquele que aprende a dizer "Nós" referindo-se aos membros de sua comunidade é capaz de compreender e aceitar o dizer-nós dos membros da comunidade vizinha; só entre eles podese estabelecer uma paz vital. ${ }^{217}$

Segundo Dascal, a tudo isto, um realista pode objetar: "Muito bonito, mas trata-se de 'pura ética'; uma utopia querer aplicá-la à realidade; a política mundial nada teria em consonância com isso. Imagine exigir para dois povos como Judeus e Palestinos que ambos devem pronunciar a palavra-princípio "Eu-Tu". Ingênuo será chamado aquele que se relacionará com o outro e se entregará a ele ou o acolherá sem reservas, em um mundo onde tudo é poder e força.

O presente estudo nos fez perceber que o caminho para a emancipação e para a liberdade está na responsabilidade que tenho para com o outro (Lévinas). Não é o "Eu" que liberta o "outro", mas o "outro" e principalmente as relações sociais que, pelo compromisso, liberta o "Eu".

Nesta perspectiva, a busca pela consciência é se "dar a perceber", e não como o projeto racionalista tentou encerrar em sua totalidade: compreender e apreender. Perceber é perceber o outro, o mundo e as coisas deste mundo. Por isso, a Educomunicação, ao promover o diálogo franco e aberto, ambiente onde se profere a palavra-princípio "Eu-Tu", reconhece o outro como infinito. Atitudes que nos oferecem uma outra forma, um outro paradigma.

Dascal coloca que: "num mundo em que todas as receitas para uma "paz instantânea" até hoje falharam, não seria o caso de abandonar o "realismo" de vista curta e dar uma chance a um "idealismo" com um pouco mais de fôlego? ${ }^{218}$

\footnotetext{
217 "Um conto hassídico, contado por Buber, ilustra vividamente esse duplo processo de voltar-se para si mesmo, abrindo-se em seguida para a comunidade. Rabi Aizik, de Krakau, filho de Rabi Iekil, que vivia em extrema pobreza, recebeu, em um sonho, a ordem de ir até Praga e procurar lá um tesouro enterrado sob a ponte que leva ao palácio do rei. Depois de sonhar três vezes a mesma coisa, pôs-se a caminho. Ao chegar à ponte, viu que estava guardada dia e noite, o que impedia de procurar o tesouro. Apesar disso, dia a dia voltava ao lugar e ficava por lá durante o dia inteiro. Por fim, o comandante da guarda perguntou-lhe o que fazia por ali. Rabi Aizik contou-lhe seu sonho, ao que o comandante da guarda riu-se às gargalhadas: "Caminhaste tanto por causa de um sonho! Que sofram os que acreditam em sonhos! Se eu acreditasse em sonho teria que ir até um lugar muito distante, pois me ordenaram em sonho que fosse até Krakau, à casa de um judeu, um tal de Aizik, filho do Iekil, e escavasse sob o seu fogão onde se encontra um tesouro. Imagine só, numa cidade em que a metade dos habitantes judeus se chama Aizik e a outra metade Iekil, certamente teria que destruir todas as casas da cidade!' - Rabi Aizik saúdo-o e voltou para casa. Lá desenterrou o tesouro que estava sob o fogão, e construiu uma sinagoga. Buber, 1964, pp. 42-3, apud. Marcelo DASCAL, Ibid., pp. 27-8.

${ }^{218}$ DASCAL, Marcelo, A idéia de paz na filosofia de Martin-Buber. In: BUBER, Martin. Do diálogo e do dialógico, São Paulo, Perspectiva, 2007, p.28.
} 
A Educomunicação, quando deixa a racionalidade ocidental, ganha as relações, resgata o diálogo e a alteridade (Lévinas). Claro que tudo isto pode ser tomado como demasiadamente místico, utópico, sonhador e tantos outros adjetivos. Porém, a ousadia está justamente nisto tudo: na mística, no sonho, no perceber o novo e não continuar a repetir velhas fórmulas que já nos demonstraram que por elas ou por intermédio delas não avançamos. É preciso ser responsável pelo outro, pois é o outro que nos liberta de um "eu" encerrado em si mesmo, caminho ainda a percorrer. 


\section{BIBLIOGRÁFIA}

ABBAGNANO, Nicola. Dicionário de Filosófia. $5^{\text {a }}$ ed., Tradução: Alfredo BOSI. São Paulo, Martins Fontes, 2007.

ADORNO, Theodor W. e Max HORKHEIMER. Dialética do esclarecimento: fragmentos filosóficos. Tradução: Guido Antonio de Almeida. Rio de Janeiro, Jorge Zahar, 1985.

ARENDT, Hannah. A condição Humana. $10^{\mathrm{a}}$ ed. Tradução: Roberto Raposo. Rio de Janeiro, Forense Universitária, 2000.

Entre o passado e o futuro. $4^{\mathrm{a}}$ ed. Tradução: Mauro W. Barbosa de Almeida. São Paulo, Perspectiva, 1997.

AYVÚ-ETÃ Comunicação e Projetos, Todos os contos: verificação do imaginário infantojuvenil - uma experiência de Educomunicação, AYVÚ-ETÃ Comunicação e Projetos e Rede ANDI Brasil, Goiânia, GO, 2004.

BABIN, Pierre, KOUlOUMDJIAN, Marie-France, Os Novos Modos de Compreender, a geração do audiovisual e do computador. São Paulo, Ed. Paulinas, 1989.

BAGGIOLINI, Luis e URBAITEL, Pablo. Adolescentes, consumo cultural y escenario urbano, v. 2, Argentina, Anuario del departamento de Ciencias de la Comunicación, año Ed. UNR , 1996/97.

BAKHTIN, Mikhail. Marxismo e Filosofia da linguagem. 9a edição. Tradução: Michel Lahud e Yara Frateschi Vieira. São Paulo, Annablume, 2002.

BOUDIEU, Pierre. Sobre La Televisión, $2^{\text {a }}$ ed., traducción de Thomas Kauf, Ed. Anagrama, Barcelona, 1998.

BOWM, David. Diálogo: comunicação e rede de convivência. Tradução: Humberto Mariotti. São Paulo, Palas Athena, 2005.

BRAGA, José Luiz, e CALAZANS, Maria Regina Zamith. Comunicação e educação: Questões delicadas na interface. São Paulo, Hacker, 2001.

BUBER, Martin. Do diálogo e do dialógico. Tradução: Marta Ekstein de Souza Queiros e Regina Weinberg. São Paulo, Perspectiva, 2007.

Eu e Tu. Tradução: Newton Aquiles Von Zuben. São Paulo, Centauro, 2001.

CANCLINI, Néstor García Consumidores e cidadãos: conflitos multiculturais da globalização, Rio de Janeiro, Ed. UFRJ, 1995. 
A Socialização da Arte teoria e prática na América Latina. tradução Maria Helena Ribeiro da Cunha e Maria Cecília Queiroz Moraes Pinto, $2^{\text {a }}$ ed., Ed. Cultrix, São Paulo,1984.

. et al., Diálogo com la obra de Jesús Martín-Barbero. Bogotá-

Colômbia, Santafé de Bogotá: Siglo Hombre Editores, Universidad Central, Departamento de Investigaciones, 1998.

CARROLL, Lewis. Aventuras de Alice no país das maravilhas. Tradução: Sebastião Uchoa Leite. São Paulo, Círculo do Livro, s/d.

CEVASCO, Maria Elisa. Para ler Raymond Williams. São Paulo, Paz e terra, 2001.

CHAUI, Marilena. Convite à Filosofia. São Paulo, Ed. Ática, 1994.

Cultura e democracia: o discurso competente e outras falas. $9^{\text {a }}$ ed.,

São Paulo, Cortez, 2001.

CITELLI, Adilson. Comunicação e educação. $3^{\text {a }}$ ed., São Paulo, Senac, 1999.

DERRIDA, Jacques. Adeus a Emmanuel Lévinas. Tradução: Fabio Landa com colaboração Eva Landa. São Paulo, Perspectiva, 2004.

DUARTE, Jorge, e Antonio BARROS. Métodos e Técnicas de pesquisa em comunicação. $2^{\mathrm{a}}$ ed., São Paulo, Atlas, 2006.

FAUSTO, Boris, História do Brasil,12a ed., São Paulo, EDUSP, 2004.

FERRY, Luc. Homo Aestheticus: A invenção do gosto na era democrática. São Paulo, Ensaio, 1994.

FESTA, Regina e SILVA, Carlos Eduardo Lins da (orgs.). Comunicação popular e alternativa no Brasil, São Paulo, Paulinas, 1986.

FIGUEIREDO, Maria do Amparo Caetano . Dialogando com Freire e Boaventura sobre emancipação humana, multiculturalismo e educação popular. Texto apresentado no $\mathrm{V}$ Colóquio Internacional Paulo Freire, Recife - 19 a 22 - setembro, 2005, p. 3.

FLUSSER, Vilém. Filosofia da caixa preta: ensaios para uma futura filosofia da fotografia. Rio de Janeiro, Relume Dumará, 2002.

FOUCAULT, Michel. A ordem do discurso. 11 ${ }^{\mathrm{a}}$ ed., Tradução: Laura Fraga de Almeida Sampaio. São Paulo, Loyola, 2004.

FRANCO, Marília da Silva. Escola Audiovisual, tese de doutorado, São Paulo, ECA/USP, 1987.

FREIRE, Alipio, ALMADA, Izaías, PONCE, J.A. de Granville (org.). Tiradentes, um presídio da ditadura: memórias de presos políticos, São Paulo, Scipione, 1997. 
FREIRE, Paulo. Pedágogia da autonomia: Saberes necessários à prática educativa. $7^{\mathrm{a}}$ ed. São Paulo, Paz e Terra, 1996.

. Pedagogia do Oprimido. 46 a ed., Rio de Janeiro, Paz e Terra, 2005.

. Educação e mudança. $31^{a}$ ed., Tradução: Moacir Gadotti e Lillian Lopes

Martin. Rio de Janeiro, Paz e Terra, 1979.

FREITAG, Bárbara, A Teoria Crítica Ontem e Hoje, São Paulo, Ed. Brasiliense, 1986.

FUNARI, Claudia Vicenza. A prática da mediação em processos educomunicacionais: $\mathbf{O}$ caso do Projeto Educom.rádio, dissertação de mestrado, ECA/USP, 2007.

GIRARDI JR., Liráucio. Pierre Bourdieu: Questões de sociologia e comunicação. São Paulo, Annablume; FAPESP, 2007.

GREENFIELD, Patrícia Marks. O desenvolvimento do raciocínio na era da eletrônica; os efeitos da TV, computadores e vidoegames. Summus, São Paulo, 1988.

GRINSPUN, Mirian P. S. Zippin (ORG). Educação tecnologia: desafios e perspectivas. 2 ed. São Paulo: Cortez, 2001.

HOHLFELDT, Antonio, Luiz C. MARTINO, e Vera Veiga (org.) FRANÇA. Teorias da comunicação: conceitos, escolas e tendência. Petrópolis: Vozes, 2001.

HUERGO, Jorge A. Hacia una genealogía de comunicaión/educación: Rastero de algunos anclajes políticos-culturales. La Plata, Argentina, Ediciones de Periodismo y Comunicación, Universidad Nacional de La Plata, 2005.

HUERGO, Jorge A. Comunicación/Educación Âmbitos, Prácticas y Perspectivas, La Plata Argentina, Ediciones de Periodismo y Comunicación, Universidad Nacional de La Plata, 1997.

KAPLÚN, Gabriel. Aprender y enseñar en tiempos de internet. Formación profesional a dintancia y nuevas tecnologías. Montevideo, 2005.

Comunicación, educación y cambio. La Habana, Caminos, 2001.

KAPLÚN, Mario. Una pedagogía de la comunicaión (el comunicador popular). La Habana: Caminos, 2002.

e HERMOSILLA, Maria Elena. La educación para los médios enla

formación Del comunicador social, Montevideo, Uruguay, Fundación de cultura universitária Licenciatura de Ciencias de La Comunicación de La Universidad de La República, 1987.

KOYRÉ, Alexandre. Do mundo fechado ao universo infinito. $4^{\mathrm{a}}$ ed. Tradução: Donaldson M. Garschagen. Rio de Janeiro, Forense Universitária, 2006. 
LEÃO, Maria Izabel, O papel da Internet nos projetos educomunicativos do NCE/USP, dissertação de mestrado, ECA/USP, São Paulo, 2008.

LÉVINAS Emmanuel. Ética e Infinito. Tradução: João Gama. Lisboa: Edições 70, 2007.

Humanismo do outro homem. 2 ed. Tradução: Pergentino S.

Pivatto (ccord.), Anisio Meinerz, Jussemar da Silva, Luiz Pedro Wagner, Magali Mendes de Menezes e Marcelo Luiz Pelizzoli. Petrópolis, RJ, Vozes, 1993.

. Totalidad e Infinito. Tradução: Daniel E. Guillot. Salamanca, Polígono El Montalvo, 2002.

. Da existência ao existente. Tradução: Paul Albert Simon e Ligia Maria de Castro Simon. Campinas, SP, Papirus, 1998.

Entre nós. $3^{\mathrm{a}}$ ed. Tradução: Pergentino Stefano Pivatto (coord.),

Evaldo Antônio Kuiava, Luiz Pedro Wagner e Marcelo Luiz Pelizolli. Petrópolis, RJ, Vozes, 2004.

LÉVY, Pierre. As tecnologias da inteligencia: o futuro do pensamento na era da informática. Tradução: Carlos Irineu da Costa. São Paulo, Ed. 34, 1993.

LÉVY, Pierre. As tecnologias da inteligência; o futuro do pensamento na era da informática, Rio de Janeiro, Ed. 34, 1993.

. Cibercultura. Tradução: Carlos Irineu da Costa. São Paulo, Ed. 34, 1999.

LIMA, Rafaela (Org.). Mídias comunitárias, juventude e cidadania. Belo Horizonte, Autêntica, 2006.

LIMA, Venício A. de. Mídia: teoria e Política. $2^{\mathrm{a}}$ ed. São Paulo, Fundação Perseu Abramo, 2007.

LOPES, Maria Immacolata Vassalo (org). Temas Contemporâneos em Comunicação, São Paulo, EDICON: INTERCOM, 1997.

Pesquisa em Comunicação. Formulação de um

Modelo Metodológico. São Paulo, Vol. XVI n. ${ }^{o}$ 2, Intercom, Revista Brasileira de Comunicação. SP, Loyola, 1993.

y NAVARRO, Raúl Fuentes (comps).

Comunicación campo e objeto de estúdio - perspectivas reflexivas latinoamericanas, México, Instituto Tecnológico y de Estudios Superiores de Occidente (ITESO).

LYOTARD, Jean - François. O Pós-moderno explicado às crianças, $2^{\mathrm{a}}$ ed. Lisboa, Portugal, Ed. Dom Quixote, 1993.

MARCONDES FILHO, Ciro (Coord. Geral). Pensar - Pulsar: Cultura comunicacional, tecnologias, velocidade. São Paulo: NTC, 1996. 
O espelho e a máscara: o enigma da comunicação no caminho do meio. São Paulo, Injuí: Discurso editorial; Unijuí, 2002.

. O escavador de silêncios: formas de construir e de desconstruir.

São Paulo, Paulus, 2004.

Para entender a comunicação: contatos antecipados com a nova teória. São Paulo, Paulus, 2008.

O principio da razão durante. Por uma filosofia do acontecimento em comunicação, São Paulo, 2008 (texto com circulação restrita).

MARÍAS, Julián. História da Filosofia. $1^{\text {a }}$ ed. São Paulo, Martins Fontes, 2004.

MARTÍN-BARBERO, Jésus. Pré-Textos, Conversaciones sobre la comunicacion y sus contextos, Coleccion Ensayo Iberoamericano, Cali - Colômbia, Ed. Centro Editorial Universidad del Valle, 1995.

. e MUNÕZ, Sonia (Coordinadores). Televisión y Melodrama, géneros y lecturas de la telenovela en Colombia. Colômbia, Ed. Tercer Mundo, 1987.

Modernidades y Destiempos Latinoamericanos. In,:

NÓMADAS, número 08, Bogotá - Colômbia, 1998.

. Comunicação e cidade: entre meios e medos. In.: Novos

Olhares, número 1, São Paulo, 1998.

Dos meios às mediações: comunicação, cultura e hegemonia. $2^{\circ}$ ed., Rio de Janeiro, UFRJ, 2001.

Heredando el futuro. Pensar la educacion desde la comunicacion, In.: NÓMADA, número 05, Bogotá - Colômbia, 1997,

La educación desde la comunicación. Colombia, Grupo

Editorial Norma, 2002.

Oficio de cartógrafo. México, Fundo de cultura econômica,

2002.

MARTINO, Luiz C. (ORG.). Teoria da comunicação: muitas ou poucas? Cotia, Ateliê, 2007.

MATTELART, Armand e Michèle. História das Teorias da Comunicação, tradução Nelson Amador, Ed. Campo das Letras, Porto, 1997.

MEAD, Margaret. Cultura y compromiso, estudio sobre la ruptura generacional, $3^{\mathbf{a}}$ ed., traducción: Eduardo Goligorsky, Barcelona - Espanha, Ed. Gedisa, 1997.

MORAN, José Manuel. Como ver televisão; leitura critica dos meios de comunicação, São Paulo, Ed. Paulinas, 1991. 
Leituras dos Meios de Comunicação, São Paulo, Ed. Pancast,

1993.

. Novas Tecnologias e o Reencantamento do Mundo, Tecnologia

Educacional, vol. 23, n. 126, setembro-outubro, São Paulo, 1995.

MORIN, Edgar. Ciência com consciência. 2 ed. Tradução: Maria D. Alexandre e Maria Alice Sampáio Dória. Rio de Janeiro, Bertrand Brasil, 1998.

OROZCO GÓMES, Guillermo. Televisión audiencias y educación. Norma, 2001.

PAIVA, Raquel (Org.). O retorno da comunidade: Os novos caminhos do social. Rio de janeiro: Mauad X, 2007.

PERUZZO, Cicilia Maria Krohling. Comunicação nos movimentos populares: a participação na construção da cidadania. $3^{\mathrm{a}}$ ed. Petrópolis, RJ, Vozes, 1998.

POIRIÉ, François. Emmanuel Lévinas: Ensaios e entrevistas. Tradução: J. Guinsburg, Mauricio Honorio de Godoy e Thiago Blumenthal. São Paulo, Perspectiva, 2007.

REALE, Giovanni, e ANTISERI, Dario. Hisótia da filosofia: Do romantismo até nossos dias. vol. 3, São Paulo: Paulus, 2005, pp. 553 - 592.

RESTREPO, Luis Carlos. O direito à ternura. 3 ed. Tradução: Lúcia M. Endlich Orth. Petrópolos, Vozes, 1998.

ROMANCINI, Richard. O campo científico da Comunicação no Brasil: institucionalização e capital científico, v. I, tese de doutorado, ECA/USP, 2006.

SARTORI, Ademilde, e Jucimara ROESLER. Educação superior a distância: gestão da aprendizagem e da produção de materiais didáticos impressos e on-line. Tubarão, Unisul, 2005.

SAVIANI, Dermival. Escola e Democracia. 39ª ed., Campinas, SP, Autores Associados, 2007.

SERRANO, Manuel Martin. A participação dos meios audiovisuais na construção da visão do mundo das crianças, In.: Projeto DEMAFOCCEB, Rio de janeiro, 1989.

SEVERINO, Antônio Joaquim. Metodologia do Trabalho Científico. $22^{\mathrm{a}}$ ed., São Paulo, Ed. Cortez, 1993.

SFEZ, Lucien. A comunicação. Tradução: Marcos Marcionilo. São Paulo: Martins Fontes, 2007.

SOARES, Ismar de Oliveira. Caminhos da Educomunicação na América Latina e nos Estados Unidos. Agenda do educom.rádio num.1, São Paulo, 9 a 16 set. 2003 Comunicação/Educação: a emergência de um novo campo e o perfil de seus profissionais. Contato, ano 1 num.2, Brasília, jan/março 1999 
. e Didoné, Iraci Maria (org). O Jovem e a Comunicação,

Loyola, 1992.

Educomunicação: as perspectivas do reconhecimento de um novo campo de intervenção social: o caso dos Estados Unidos. Eccos Revista Científica Uninove (v.2 n.2), São Paulo, dez 2000b.

Lei de Diretrizes e Bases e a Comunicação no sistema de ensino. Revista Comunicação \& Educação (8), São Paulo, 1997, p.23-26.

. Sociedade da informação ou da comunicação. São Paulo,

Cidade Nova, 1997.

Metodologias da educação para comunicação e gestão comunicativa no Brasil e na América Latina in BACCEGA, Maria Aparecida, Gestão de processos comunicacionais ,São Paulo-SP, Atlas, 2002

Professores e meios de comunicação: desafios, estereótipos. Revista Comunicação \& Educação (10), São Paulo, set/dez 1997, p.57-68

SOUSA, Mauro Wilton de (org). Sujeito, o lado oculto do receptor. São Paulo, Brasiliense e ECA-USP, 1995.

(Org.). Recepção mediática e espaço publico: novos olhares.

São Paulo, Paulinas, 2006.

Novas Linguagens. São Paulo, Salesiana, 2001.

STRASBURGER, Victor C. Os Adolescentes e a Mídia: impacto psicológico, tradução Dayse Batista, Porto Alegre, Ed. Artes Médicas Sul, 1999.

TEIXEIRA COELHO, Neto. Dicionário crítico de políticas Culturais: cultura e imaginário, São Paulo, Ed. Iluminuras e FAPESP, 1997.

THOMPSON, John B. Ideologia e Cultura Moderna, teoria social crítica na era dos meios de comunicação de massa, Ed. Vozes, Petrópolis, RJ, 1995.

TORRE, Alberto Efendy Maldonado Gómes de la. Teorías da comunicação na América Latina. São Leopoldo, UNISINUS, 2001.

TOURAINE, Alain. Crítica da Modernidade, $4^{\mathrm{a}}$ ed., tradução Elia Ferreira Edel, Petrópolis, RJ, Vozes, 1994.

UniRede e SSED/MEC/Coordenação de Leda Maria Rangearo e Vânia Lúcia Quintão Carneiro. TV a escola e os desafios de hoje: Curso de Extensão para Professores do Ensino Fundamental e Médio da Rede Publica. $2^{\text {a }}$ ed. 1, 2 e 3 vols. Brasília: Universidade de Brasília, 2001. 
WIGGERSHAUS, Rolf. A Escola de Frankfurt: História, desenvolvimento teórico, significação política. Tradução: Lilyane Deroche-Gurgel e Vera de Azambuja Harvey.

WILLIAMS, Raymond. Cultura. Tradução: Lólio Lourenço de Oliveira, Rio de Janeiro:

WOLF, Mauro. Teorias da Comunicação, 4 ed., tradução Maria Jorge Vilar de Figueiredo, Lisboa-Portugal, Ed. Presença, 1995.

ZITKOSKI, Jaime José. Paulo Freire \& Educação. Belo Horizonte, Autêntica, 2006. 